IZA DP No. 9072

The Rising Cost of Child Care in the United States:

A Reassessment of the Evidence

Chris M. Herbst

May 2015 


\title{
The Rising Cost of Child Care in the United States: A Reassessment of the Evidence
}

\author{
Chris M. Herbst \\ Arizona State University \\ and IZA
}

\author{
Discussion Paper No. 9072 \\ May 2015
}

IZA
P.O. Box 7240
53072 Bonn
Germany

\author{
Phone: +49-228-3894-0 \\ Fax: +49-228-3894-180 \\ E-mail: iza@iza.org
}

\begin{abstract}
Any opinions expressed here are those of the author(s) and not those of IZA. Research published in this series may include views on policy, but the institute itself takes no institutional policy positions. The IZA research network is committed to the IZA Guiding Principles of Research Integrity.

The Institute for the Study of Labor (IZA) in Bonn is a local and virtual international research center and a place of communication between science, politics and business. IZA is an independent nonprofit organization supported by Deutsche Post Foundation. The center is associated with the University of Bonn and offers a stimulating research environment through its international network, workshops and conferences, data service, project support, research visits and doctoral program. IZA engages in (i) original and internationally competitive research in all fields of labor economics, (ii) development of policy concepts, and (iii) dissemination of research results and concepts to the interested public.
\end{abstract}

IZA Discussion Papers often represent preliminary work and are circulated to encourage discussion. Citation of such a paper should account for its provisional character. A revised version may be available directly from the author. 


\title{
ABSTRACT \\ The Rising Cost of Child Care in the United States: A Reassessment of the Evidence ${ }^{1}$
}

\begin{abstract}
Anecdotal evidence suggests that the cost of child care in the U.S. has increased substantially over the past few decades. This paper marshals data from a variety of sources to rigorously assess the issue. It begins by using nationally representative survey data to trace the evolution in families' child care expenditures. I find that the typical family currently spends 14 percent more on child care than it did in 1990. This is less than half the increase documented in previous work. Interestingly, low-income families spend the same amount or less on child care, while their high-income counterparts spend considerably more. Despite this divergence, families at all income levels allocate the same share of income to child care as they did several decades ago. The next section of the paper draws on establishment- and individual-level data to examine trends in the market price of child care. The evidence suggests that after persistent, albeit modest, growth throughout the 1990s, market prices have been essentially flat for at least a decade. In the paper's final section, I analyze several features of the child care market that may have implications for prices, including the demand for child care, the skill-level of the child care workforce, and state regulations. A few findings are noteworthy. First, I show that child care demand stagnated around the same time that market prices leveled-off. Second, although the skill-level of the child care workforce increased in absolute terms, highly-educated women increasingly find child care employment less attractive than other occupations. Finally, child care regulations have not systematically increased in stringency, and they appear to have small and inconsistent effects on market prices. Together, these results indicate that the production of child care has not become more costly, which may explain the recent stagnation in market prices.
\end{abstract}

JEL Classification: $\quad 128, \mathrm{J01}, \mathrm{J08}, \mathrm{J} 20$

Keywords: child care costs, child care demand, child care regulations, parental employment

Corresponding author:

Chris M. Herbst

School of Public Affairs

Arizona State University

411 N. Central Ave., Suite 420

Phoenix, AZ 85004-0687

USA

E-mail: chris.herbst@asu.edu

\footnotetext{
${ }^{1}$ This paper benefitted from useful conversations and exchanges with Erdal Tekin, David Blau, Lynda Laughlin, Joanna Lucio, and Spiro Maroulis. I am grateful to Daphna Bassok for generously sharing her data on child care regulations.
} 


\section{Introduction}

To what extent has the cost of child care in the U.S. increased over the past few decades? Interest in this question has grown considerably in recent years, with anecdotal evidence and press reports suggesting that child care costs have grown to the point of inflicting serious financial hardship on families. Indeed, recent estimates indicate that the annual cost of infant, center-based care exceeds one year of tuition at public universities in 31 states (Child Care Aware, 2014). Some observers argue that rising costs are symptomatic of a deeper child care market problem, while others cite the increase as one explanation for the decline in mothers' labor force participation. Such concerns recently touched off a vigorous public debate culminating in a series of policy proposals to expand several child care assistance programs. ${ }^{2}$

Unfortunately there is very little systematic evidence to support the claim that the cost of child care has risen or that it has become more financially burdensome. The goal of this paper, therefore, is to carefully document the evolution in child care costs over the past few decades. It does so by examining three interrelated topics. The paper begins by analyzing nationally representative survey data capturing changes in families' utilization of and expenditures on non-parental care. It then analyzes the market price of child care, focusing on the trend in private- and public-sector prices as well as those in the formal and informal sectors. The paper ends with an auxiliary analysis of several key features of the child care market — including the demand for child care, the skill-level of the child care workforce, and labor-related child care regulations - all of which may have implications for the market price.

To analyze families' child care expenditures, I conduct a careful analysis of the Survey of Income and Program Participation (SIPP), which collects arguably the most detailed information on

\footnotetext{
${ }^{2}$ For example, a recently introduced Senate bill called the Right Start Child Care and Education Act raises the Child and Dependent Care Tax Credit's (CDCTC) credit rate on eligible child care expenses, increases the maximum amount eligible for the credit, and makes the credit refundable. In addition, several states, including Minnesota and Michigan, proposed their own child care tax credits. In his recent State of the Union address, President Obama proposed a major expansion to the Child Care and Development Fund (CCDF) - a means-tested child care subsidy program - that provides financial assistance to all families below 200 percent of the Federal Poverty Line.
} 
children's participation in and family expenditures on non-parental arrangements. Since 1985, SIPP's Child Care Topical Module has been administered 23 times, providing information on the evolution in child care expenses over a considerable period. This historical series is updated periodically through an ongoing Census Bureau report entitled Who's Minding the Kids?, the most recent of which presents child care expenditure data between 1985 and 2011 (Laughlin, 2013). A reanalysis of the SIPP is warranted because, as highlighted in the latest Who's Minding the Kids?, these data reveal a large rise in child care expenditures (Laughlin, 2013). Figure 1, which presents an adaptation of the Census Bureau figures, shows that average weekly expenditures among working families grew from $\$ 87$ in 1985 to $\$ 148$ in 2011, an increase of 71 percent (in constant 2013 dollars). ${ }^{3}$

My analysis of the SIPP compares child care expenditures in the 1990 Panel (Wave 3) with those in the 2008 Panel (Wave 8), which correspond to the Fall of 1990 and the Winter/Spring of 2011, respectively. This period spans nearly all of years covered in the original Census Bureau analysis. To ensure that child care expenditures are measured consistently over time, the analysis must account for several factors. First, the SIPP child care survey underwent numerous changes that may have implications for the measurement of child care expenses. Second, the analysis should account for changes in labor supply. If hours of work increased over time-leading to a commensurate rise in child care expenses and earnings - it is unclear whether the cost of employment increased per se, nor is it certain that child care became more financially burdensome. Therefore, comparisons in this paper are based on a measure of weekly child care expenditures per hour of work by the primary caretaker. A related issue is that changes in the type of child care used by families should be taken into account. If families increasingly use formal care, including centerbased and preschool services, which are known to be more costly than informal arrangements, this might further explain the purported rise in child care expenses. Finally, I report all expenditure

\footnotetext{
${ }^{3}$ Specifically, Figure 1 in this paper recreates the time trend displayed in Figure 5 of Laughlin (2013). The only differences are that Figure 1 shows the weekly expenditure amounts in constant 2013 dollars, rather than 2011 dollars, and Figure 1 shows the percent change in weekly expenditures, using 1985 as the base year. The Laughlin (2013) report does not show percent change calculations. The raw data for both figures can be found here: http://www.census.gov/programs-surveys/sipp/data/tables/historical-tables.html
} 
figures in terms of the median, rather than the mean, as is done in the Who's Minding the Kids? reports, because the mean is increasingly influenced by a relatively small number of families spending a large amount on child care. In other words, the mean over time became a less accurate measure of what the "typical" family spends on child care.

Key results from the SIPP analysis are as follows. First, the share of families paying for child care declined substantially_from 37 to 27 percent—between 1990 and 2011. Second, among those making payments, median child care expenditures per hour of work grew from $\$ 2.27$ to $\$ 2.59$, an increase of 14 percent. This is less than half the increase documented over the same period in Figure 1 (39 percent). However, this relatively modest rise in child care costs masks substantial heterogeneity across different arrangements and families. For example, expenditures on informal arrangements (e.g., relative and neighbor care) declined in real terms, while those on formal arrangements (e.g., center and preschool care) increased. Furthermore, economically disadvantaged families, as defined by maternal education and household income, witnessed flat or falling child care expenses, while their advantaged counterparts spent considerably more over time. To take a striking example, hourly expenditures on center-based arrangements by families with low-education mothers declined 18 percent between 1990 and 2011. In contrast, expenses among their high-education counterparts increased 23 percent. Nevertheless, despite these diverging trends families at all income levels currently allocate as much income to child care as they did several decades ago.

In the next section of the paper, I turn my attention to the market price of child care. I do so because the trend in market prices should reflect in large part whether, and to what extent, families' expenses are rising or falling. Given that state- or national-level data on child care prices are not available, I rely on the earnings of child care workers to proxy market prices. Consistent with Blau's (1992; 2001) insights, I provide evidence from two datasets - the Cost, Quality and Child Outcomes Study (CQCOS) and the Economic Census (EC) - that the child care industry is unusually labor intensive. For example, data from the CQCOS, which collected cost and revenue information on 
approximately 400 child care centers, show that labor costs, including wages and benefits, account for as much as 80 percent of centers' total operating costs. That labor is the primary input to the production of child care suggests that the time trend in earnings can serve as a reasonable proxy for the trend in market prices. My analysis draws on three high-quality data sources: establishment-level data from the Quarterly Census of Employment and Wages (QCEW) and the Occupational Employment Statistics survey (OES) as well as individual-level data from the Current Population Survey (CPS). Among the key advantages of these datasets are that they provide consistent measures of annual earnings for child care workers in a variety of industry and occupational categories over a considerable period of time.

Although the datasets are quite varied in terms of the breadth and depth of information collected, the results are remarkably consistent: following sustained, albeit modest, growth throughout the 1990s, the earnings of child care workers have been essentially flat since the early2000s. This holds for public and private child care industry employees, child care workers in nonchild care industries (e.g., religious organizations), those in instructional (e.g., teacher's assistants) and support (e.g., food preparation) occupations, and for formal and informal caregivers. For example, the annual earnings of private workers grew from $\$ 16,180$ to $\$ 19,891$ between 1990 and 2003, an increase of 23 percent. A decade later, in 2013, their earnings were effectively unchanged at $\$ 19,962$. In addition, child care workers in every state but one experienced positive earnings growth throughout the 1990s; since 2003, however, those in about half the states witnessed a reduction in real earnings. Thus a tentative conclusion is that the market price of child care increased throughout the 1990s, but has remained flat or even declined somewhat since the early-2000s.

In the final section of the paper, I provide a set of supplementary analyses intended to examine various features of the child care market that may have implications for the market price. This section begins by analyzing the evolution in the demand for non-parental care, as measured by mothers' labor force participation and children's utilization of formal services. Using March and 
October CPS data between 1985 and 2014, I find that labor force and child care participation increased steadily until the early-2000s, after which no further increases are observed. Such evidence indicates that the demand for child care has been stagnant for at least a decade. It is also noteworthy that these participation patterns are quite similar to the time trend discussed above for child care workers' earnings.

Next, I examine trends in the skill-level of the child care workforce-as defined by educational attainment - followed by a formal empirical analysis of the effect of skill on child care employment and prices (i.e., wages). Education is a key input to child care quality, which in turn influences the cost of production. Therefore, changes in educational attainment should be reflected in the market price of child care. I find that although the child care workforce experienced an absolute increase in skill over the past few decades, such workers became less skilled than their female counterparts in other occupations. In particular, the gap in college completion widened substantially between most child care workers and other female workers. Estimates from a model of sectoral choice largely confirm these trends: education is positively correlated with employment in most child care sectors, but the degree to which highly-educated women are drawn to child care employment has declined over time. Given that the child care industry has not become more attractive to highskilled workers, it is unlikely that education is a source of upward pressure on wages and prices.

Lastly, I explore changes in several labor-related child care regulations, including staff educational qualifications, staff-to-child ratios, and maximum group sizes in center-based settings. I also conduct a reduced form analysis of the effect of regulations on the supply and market price of child care. Such analyses are important because some observers assert that growing regulatory stringency is a potential explanation for the rising cost of child care. Indeed, assuming that child care regulations are binding and enforced, economic theory generally predicts that tougher regulations will decrease supply and increase prices. However, I find no consistent evidence that states' centerbased regulations have become stricter over time. In fact, several regulatory domains-including 
education requirements for directors, staff-to-child ratios for older children, and group sizes - have grown more lenient. Results from the empirical analysis suggest that tightening regulations is not consistently associated with higher prices, and in fact some regulations may lower them, a result that is not entirely inconsistent with economic theory. Overall the evidence suggests that regulations are not likely to have had a large effect on the child care market over the past few decades.

The remainder of the paper proceeds as follows. Section II provides a comprehensive analysis of families' child care expenditures using the SIPP. Section III examines the time trend in the market price of child care across multiple industry and occupational categories and in the formal and informal sectors. Section IV examines issues related to the demand for child care, the skill-level of the child care workforce, and states' child care regulatory regimes. Finally, Section V concludes with a brief discussion of policy implications.

\section{Families' Child Care Expenditures}

\section{Data Description and Measures}

Administered by the U.S. Census Bureau, the SIPP comprises a series of nationally representative panels, with sample sizes ranging between 14,000 and 37,000 households. It is designed as longitudinal survey, such that households participate in a series of interviews over a period of two to four years. To reduce respondent burden, households are assigned to one of four rotation groups, each of which is interviewed in successive months. The four-month period required to interview all of the rotation groups is called a wave. A new wave begins as soon as the previous one concludes; thus each household is interviewed once every four months.

Although the SIPP survey focuses on a large number of "core" labor force, program participation, and income questions, it is supplemented by several "topical" modules, one of which covers child care. A typical Child Care Module collects information on the utilization of child care arrangements and organized activities for children ages 0 to 14 , the number of hours per week children spend in care, and the expenditures associated with each arrangement. It is one of the most 
commonly used data sources to study questions related to child care prices and maternal labor supply (e.g., Anderson \& Levine, 2000; Herbst, 2010; Connelly \& Kimmel, 2003a, b). ${ }^{4}$

This paper examines child care expenditures using Wave 3 of the 1990 Panel, covering the Fall of 1990, as well as Wave 8 of the 2008 Panel, covering the Winter and Spring of 2011. The depth of coverage in the Child Care Module increased substantially over time, necessitating a number of adjustments in order to ensure consistency in the child care cost calculations. In the 1990 Panel, the child care questions were directed at the primary parent or guardian ages 15 and over, who was employed, looking for a job, or attending school. Information was collected on the primary and, if relevant, secondary arrangement for the three youngest children (ages 0 to 14 ) in the family. As of the 2008 Panel, the survey was expanded to include non-working parents or guardians as well as all child care arrangements for the five youngest children. To maintain consistency, this paper examines expenditures incurred for (i) families in which the primary parent or guardian is employed or in school, (ii) the primary and secondary child care arrangements, and (iii) the three youngest children ages 0 to $14 .^{5}$

The other major change in the 2008 SIPP is the more expansive list of child care arrangements in which a child may participate. For example, the category for sibling child care was split into two categories (based on the age of the sibling providing care), and explicit categories for family day care; Head Start; and organized sports, lessons, and clubs were added. In addition, some arrangements in the 2008 SIPP are available only to parents with children ages 0 to 5 (e.g., nursery school and Head Start), while others are available to those with children ages 6 to 14 (e.g., sports,

\footnotetext{
${ }^{4}$ SIPP data and documentation can be found here: http://www.census.gov/sipp/. Several of the Who's Minding the Kids? reports can be accessed here: http://www.census.gov/programs-surveys/sipp/publications/sipp-pubs-auto.html.

${ }^{5}$ Maintaining consistency was made further difficult by changes in the information available to identify the primary and secondary arrangement. In the 1990 SIPP, parents were asked by the interviewer to identify the primary arrangement as the one used for the greatest number of hours while at work during a typical week in the reference month. The secondary arrangement was identified as the one used "during most of the other hours" during the week. In the 2008 SIPP, parents were asked about the number of weekly hours of participation in each child care arrangement. Using this information, the primary and secondary arrangements are defined by the researcher as those used for the largest and second largest number of hours per week, respectively. However, two hours-of-use questions are available in the 2008 SIPP, with one asking about the total number of hours and the other asking about hours-of-use while the parent was at work. Reported hours for these variables are often very similar (or identical), but they can be quite different for some families. This paper relies on the latter question (i.e., hours-of-use during work) to determine the primary and secondary child care arrangement, given its similarity to the 1990 SIPP identification scheme.
} 
lessons, and clubs). The remaining arrangements are available to all ages. The 1990 SIPP makes no such age distinctions.

It is important to create a consistent set of child care arrangements across the 1990 and 2008 Panels because some analyses compare expenditures over time within a given arrangement. As shown in Appendix Table 1, I pair each arrangement in the 1990 SIPP with one or more arrangements in the 2008 SIPP, and then combine the individual arrangements to form a set of nine child care categories. It is straightforward in most cases to pair a child care arrangement from the 1990 Panel with one in the 2008 Panel. However, in a few cases the pairing may seem arbitrary, and so some discussion is warranted. To create the category "family-based care," I pair 1990 children participating in non-relative care outside the home with 2008 children using "family day care." This has implications for the "non-relative" category, which pairs 1990 children participating in non-relative care inside the home with 2008 children using any type of non-relative care. To create the category “preschool/nursery school," I first combine 2008 children participating in Head Start, nursery school, or preschool, and then I pair them with 1990 children using nursery school or preschool. Finally, the 1990 Panel includes a broad category called “organized school-based activity," while the 2008 Panel includes separate categories for before and after school programs, sports, lessons, and clubs. In addition, parents in the 2008 Panel indicate whether the child participates in these activities inside or outside school. I create an arrangement called "school-based activity" by pairing the single 1990 category with the multiple 2008 categories if children in the 2008 survey participate inside school. ${ }^{6}$

The SIPP analysis compares families in 1990 and 2011 along three dimensions: the fraction of families paying for child care, the amount paid per week, and the share of monthly income spent on child care. Both Child Care Modules ask parents using child care whether any monetary payment

\footnotetext{
${ }^{6}$ In other words, children participating in sports or clubs or taking lessons outside school are not defined to be participating in the child care arrangement called "school-based activity." Given that these options are available only to children ages 6 to 14, and that school is the most prominent child care "arrangement," very few children are coded as using these school-based activities as the primary or secondary arrangement. Nevertheless, of those participating in sports or clubs or taking lessons, a considerable number do so outside school, thereby making the within-school participation constraint important to the definition of "school-based activity."
} 
was made for the child's arrangement. Recall that these questions were asked about a maximum of two arrangements for the three youngest children in the 1990 SIPP, but were asked about all arrangements for the five youngest children in the 2008 SIPP. I construct the pay-for-care variable through a binary indicator that equals unity if a given parent reports making a monetary payment for the primary or secondary child care arrangement across the three youngest children, and zero if no payment was made for these arrangements. This variable is likely to understate slightly the fraction of families paying for child care given that it does not consider costs incurred starting with the fourth youngest child, and it ignores the costs associated with higher-order arrangements. ${ }^{7}$

To construct the measure of child care expenditures, I rely on questions in the 1990 and 2008 surveys that inquire about the amount paid for a given arrangement in a typical week. I sum expenditures over the primary and secondary arrangement for the three youngest children in the family. Two variables are discussed in the paper: total weekly child care expenditures and expenditures per hour of work or school attendance by the primary parent or guardian. As previously stated, the latter measure is preferred because it accounts for the intensity of labor supply. In other words, this measure captures changes over time in the fixed cost of parental employment. I sum hours of work over the primary and, if relevant, secondary job. As others note, it is difficult to determine whether these variables capture the total cost of providing care or the net-of-subsidies (i.e., out-of-pocket) cost, although a reasonable assumption is that the latter is generally reported by parents (Rosenbaum \& Ruhm, 2007). All expenditures are reported in constant 2013 dollars.

Finally, I create a measure of the percent of monthly income spent on child care by dividing child care expenditures by total household income (expressed in 2013 dollars). Household income includes wages and salary, government transfers (e.g., Social Security, Unemployment Insurance, and AFDC/TANF), intra-family payments from child support and alimony, and other sources of non-

\footnotetext{
${ }^{7}$ There are few families in the data with four or more children, and few children participating in three or more arrangements.
} 
wage income (e.g., pensions and rental income). ${ }^{8}$ These amounts are reported for each of the four months in which the family appears in a wave. I calculate the average income over this four-month period in order smooth short-run income fluctuations and mitigate the influence of reporting errors. In addition, both surveys contain a small number of families with implausibly large child care expenditure shares, some with percentages that exceed 100 percent. As these are likely due to the misreporting of child care expenses or income, I follow Rosenbaum and Ruhm (2007) and cap the expenditure share variable at 50 percent. ${ }^{9}$ Given that child care expenditures are reported as weekly amounts and household income as monthly amounts, I align the two by multiplying child care expenditures by 52 (weeks) and dividing by 12 (months).

\section{Results}

Table 1 provides the full sample results for the fraction of families with children ages 0 to 14 paying for child care and the weekly amount paid (conditional on paying). The 1990 SIPP sample contains 4,861families, while the 2008 sample contains 6,513 families. All of the estimates are weighted using the SIPP final person weight. The first row attempts to recreate the pay-for-care and weekly expenditure figures reported in the most recent Who's Minding the Kids? (Laughlin, 2013). Specifically, these figures do not adjust for the changes in the Child Care Module's design, and weekly expenditures are expressed as means rather than medians. However, consistent with the Census Bureau's report, the estimates presented here are based on samples in which the parent is working or attending school. ${ }^{10}$ As shown in the first row, approximately 37 percent of families in 1990 paid for child care. Of those, the mean weekly expenditure was \$101. By 2011, the fraction

\footnotetext{
${ }^{8}$ Some may quibble with the use of household income (as opposed to family income or mothers' earnings) as the denominator in the child care expenditure share ratio. I use total household income because I make the assumption that all monetary resources can be made available by families to pay for child care, including sources of labor and non-labor income from immediate and extended family members residing under the same roof.

${ }^{9}$ Reducing the ceiling on the expenditure share variable (to 50 percent of income) omits 26 families from the 1990 SIPP analysis and 49 families from the 2008 analysis.

${ }^{10}$ Although I make every attempt in the first row of Table 1 to recreate the estimates presented in Laughlin (2013), there is one difference of which I am aware: the Census Bureau estimates are based on samples of women, while the estimates in Table 1 (and throughout the paper) include men and women. Respondents in the SIPP Child Care Modules are overwhelmingly female, and so including men in the analysis does not substantially explain the divergence between the Census Bureau results and those presented here.
} 
paying had fallen to 31 percent, while weekly expenditures rose to $\$ 134$, representing an increase of 33 percent. The second row adjusts the pay-for-care and expenditure estimates in the 2008 SIPP so that only the primary and secondary arrangements for the three youngest children are taken into account. Interestingly, these revised estimates imply a larger reduction in the fraction of families paying for child care-from 37 to 27 percent-and a larger increase in average weekly expenditures - from $\$ 101$ to $\$ 139$ — corresponding to a 38 percent rise in child care costs.

One concern with reporting the mean of child care expenditures is its increased sensitivity to a relatively small number of families spending a large amount on child care. Indeed, the standard deviation on weekly expenditures more than doubled between the 1990 and 2008 SIPPs (from $\$ 67$ to \$143). In addition, whereas expenditures at the $75^{\text {th }}$ percentile totaled $\$ 134$ in the 1990 SIPP, they were $\$ 181$ in the 2008 SIPP, an increase of 35 percent. These data suggest that the mean increasingly provides an imprecise picture of what the "typical" family spends on child care. Therefore, the third row in Table 1 presents the median expenditure, which reveals a substantially smaller rise in weekly child care costs—-from $\$ 89$ to $\$ 104$ - an increase of 16 percent.

The last two rows in Table 1 make one final adjustment to the calculation of families' child care costs: it scales weekly expenditures by the number of hours of parental employment or school attendance. This adjustment is necessary to account for changes in the intensity of work over time. For example, if hours of work increased for some groups of mothers-leading to a commensurate rise in child care expenses and earnings - then a measure of weekly costs does not capture changes in the fixed cost of parental employment. Scaling weekly expenditures by hours of work can be seen as a type of "control" for changes in labor supply, thereby allowing for a meaningful comparison of what it costs a family to purchase child care in multiple periods. The fourth row in Table 1 presents mean child care expenditures per hour of work, while the last row presents median hourly costs. Median costs rose from \$2.27 in 1990 to \$2.59 in 2011, an increase of 14 percent. This is considered 
the baseline increase in families' child care expenditures, and it implies that such costs grew by a substantially smaller amount than has been reported.

Table 2 repeats the exercise described above, this time on stratified samples of families whose youngest child is ages 0 to 5 (Panel A) and ages 6 to 14 (Panel B). Families with preschoolage children are more likely to pay for child care than those with school-age children, and when they do, they pay considerably more. However, families with preschool-age children became substantially less likely to pay for child care between 1990 and 2011 (59 to 41 percent), while those with schoolage children remained equally likely to pay (15 percent). Also noteworthy is that the 14 percent rise in expenditures reported in Table 1 appears to be driven by the sizeable increase experienced by families with preschool-age children. Median costs for this group increased from $\$ 2.67$ per hour in 1990 to $\$ 3.45$ in 2011 (or 29 percent), while costs for families with school-age children actually declined in real terms, from $\$ 1.34$ to $\$ 1.24$ (or 8 percent).

To further examine heterogeneity in child care expenditures, the results in Table 3 are based on more refined subsamples. Specifically, I present pay-for-care and expenditure estimates for families with preschool-age (Panel A) and school-age (Panel B) children, disaggregated by parental marital status and educational attainment as well as household income. Looking first at families with preschool-age children, it is clear that economically advantaged families (i.e., those with married and highly educated parents and those with high incomes) are more likely to pay for child care than their disadvantaged counterparts. However, it appears that all family-types became considerably less likely to pay between 1990 and 2011. It is also noteworthy that disadvantaged families experienced very little change in their child care expenses, while advantaged families saw their expenses rise sharply. For example, child care expenditures by families in the bottom quartile of income increased from $\$ 2.23$ per hour in 1990 to $\$ 2.46$ in 2011 (or 10 percent). For families in the top income quartile, costs grew from $\$ 3.34$ to $\$ 4.93$ (or 48 percent). This widening gap in child care expenditures is evident across unmarried and married parents as well as low- and high-education parents. Turning to families 
with school-age children, it appears that most demographic groups witnessed a reduction in child care expenses. For some groups, these reductions have been fairly steep. For example, highly educated parents spent 19 percent less on child care, while those in the top income quartile spent nearly 30 percent less.

The next several analyses change the unit of analysis from the family to the child so that expenditures on specific child care arrangements can be examined. This exercise is important because it is possible that preferences for different child care arrangements have evolved in such a way as to fundamentally change families' child care costs. For example, there is some evidence that families increasingly select into formal modes of early care and education (e.g., pre-kindergarten, nursery school, and center-based care), which may be more expensive than informal child care, thereby artificially inflating family-level cost comparisons in a time series (Magnuson et al., 2007). By switching to a child-level dataset, the following analyses shed light on whether, and by how much, expenditures on specific child care arrangements increased over time.

To motivate the forthcoming analyses, Table 4 presents participation rates for nine child care arrangements in the 1990 and 2008 SIPP surveys. Panel A shows participation rates for children ages 0 to 5, while Panel $\mathrm{B}$ shows participation rates for children ages 6 to 14 . These analyses are constrained to the primary child care arrangement, defined as the one in which the child spends the greatest number of hours per week. ${ }^{11}$ Appendix Table 1 provides information on how the child care arrangement categories were constructed. Looking first at preschool-age children, the predominant modes of child care in both years are parent and relative care, followed by center-based care and various forms of school-based care (e.g., nursery school and kindergarten). The use of relative care increased between 1990 and 2011, as did the use non-relative care-which includes in-home nannies

\footnotetext{
${ }^{11}$ Some child care arrangements are "tied" for the designation as the primary arrangement, in the sense that a given child participates in two or more arrangements for the same number of hours. This paper treats such cases as co-primary arrangements: all arrangements are used to calculate the participation rates in Table 4, and the expenditures associated with them are used in the forthcoming child-level analysis. As a result, the participation rates in Table 4 sum to over 100 percent.
} 
and babysitters - as well as formal school participation. These increases were offset by falling participation in center- and family-based care. However, the latter decline should be interpreted cautiously, as the definition of family-based care underwent major changes in between the SIPP surveys. Not surprisingly, the primary arrangement for school-age children is school attendance, followed by parent and relative care.

Table 5 reports median weekly and hourly expenditures on paid child care arrangements for preschool-age children. The analysis omits school-age children given that the predominant arrangement - school-based participation — is treated as an unpaid arrangement in the SIPP Child Care Module. ${ }^{12}$ The picture emerging from this analysis is that expenditures on informal child care arrangements decreased in real terms between 1990 and 2011, while payments on formal arrangements increased by a non-trivial amount. Specifically, expenditures per hour of work on relative and non-relative arrangements fell eight percent and 14 percent, respectively, while those on center-based and preschool/nursery arrangements increased 25 percent and 30 percent, respectively. The cost of family-based care, meanwhile, rose only modestly (11 percent).

Table 6 repeats the analysis above, but this time it disaggregates the expenditure figures by parental marital status and educational attainment. To ensure sufficient observations, it combines the non-relative and family-based arrangements into a unified category. The same approach is taken with the center-based, preschool, and nursery school arrangements. This table omits the comparisons by income quartile, as there are insufficient observations. It is clear that the evolution in child care expenditures varies substantially depending on family-type. Expenditures by economically disadvantaged families declined across virtually every child care arrangement. Among parents with no more than a high school degree, for example, median hourly payments to relatives fell 28 percent; payments to non-relatives fell 0.5 percent; and payments to center-based providers fell 18 percent.

\footnotetext{
${ }^{12}$ As shown in Appendix Table 1, the Child Care Module does not ask about expenditures for all child care arrangements. Specifically, the survey treats parent (including the primary parent and stepparent), sibling, school-based, and self-care arrangements as unpaid arrangements. Of course, it is possible that a stepparent or older sibling could be paid to provide child care, but these expenses are not observed in the Child Care Module.
} 
Conversely, expenditures by parents with more than a high school degree increased across every category, especially center-based arrangements. In 1990, such parents spent \$2.94 per hour on centerbased care, an amount that increased to $\$ 3.62$ in 2011 (or 23 percent).

To this point, the analysis has focused on the absolute change in families' child care expenditures. The final analysis in this section asks a different question: have child care costs grown relative to families' ability to pay? This question speaks to whether child care is becoming increasingly financially burdensome for families. As shown in Table 7, I attempt to answer this question by calculating the percent of monthly income spent on child care, once again using data from the 1990 and 2008 SIPP. Panel A shows the expenditure share for families with children ages 0 to 5, while Panel B shows the comparable figures for children ages 6 to 14. Within each age group, percentages for the full sample and several demographic sub-groups are shown.

Looking first at Panel A, it appears that, on average, families with preschool-age children allocated only slightly more of their income to child care in 2011 (11 percent) than in 1990 (nine percent). Although the expenditure share among disadvantaged families is higher than it is among their advantaged counterparts, the latter actually experienced more growth in the cost burden over time. For example, the expenditure share for families in the bottom income quartile rose from 16.5 to 17.4 percent (or 6 percent) between 1990 and 2011, while the share for families in the top income quartile grew from 5.3 to 7.8 percent (or 47 percent). Turning to Panel B, it is clear that families with school-age children experienced a declining child care cost burden over time. Overall, the expenditure share fell from 6.2 to 5.0 percent between 1990 and 2011. In addition, families from nearly all socioeconomic strata have seen their cost burden decline.

\section{Discussion}

The preceding analyses reveal a number of noteworthy findings. Today U.S. families with children are substantially less likely to pay for child care than their counterparts several decades ago. This decline is evident across all socioeconomic groups. Among families that pay for child care, 
expenditures by the typical family increased only modestly. Indeed, I find that median expenditures per hour of work grew 14 percent between 1990 and 2011. However, there is substantial heterogeneity across different families and child care arrangements. Families with preschool-age children experienced a considerable increase in their child care costs, while those with school-age children actually saw their expenses decline slightly. Furthermore, within the subset of families with preschool-age children, the increase in child care expenditures has been driven almost exclusively by economically advantaged families. Those in the top income quartile witnessed about a 50 percent increase in child care expenses, while those in the bottom quartile saw only a 10 percent increase. These socioeconomic divisions are evident once again when the analysis compares expenditures within a given child care arrangement. Finally, I show that child care has not become more financially burdensome for the typical family. Between 1990 and 2011, parents of preschoolers spent only slightly more of their income on child care, while parents of school-age children spent somewhat less of their income on child care.

The declining share of families paying for child care is noteworthy because it implies a large extensive-margin-driven reduction in families' child care expenses. Indeed, if non-paying families are included in the expenditure analysis, the results suggest that costs per hour of work declined dramatically over the past few decades. That a smaller portion of families is paying for child care is not surprising in light of the shift in the types of child care utilized. Preschool-age children are more likely to be cared for by providers that are less likely charge for their services: parents, stepparents and other relatives, and school-based providers. In addition, the use of family-based care-an arrangement that is likely to charge its clients-has declined, although this finding should be interpreted cautiously given the definition change noted earlier. The increasing share of four- and five-year-olds enrolled in school-based settings (from nine to 14 percent) is an important development, as some have referred to kindergarten and school enrollment more generally as an implicit 100 percent child care subsidy (Gelbach, 2002). However, it is possible that some parents are 
misreporting their child's attendance in Head Start or pre-kindergarten as "school" enrollment, given that many of these early education programs operate out of public schools. Nevertheless, given that some Head Start and pre-kindergarten programs provide services free-of-charge, it appears that greater utilization of school-based services, however defined, could be an important explanation for the declining share of families paying for child care.

Also noteworthy is the growing income-based gap in child care expenditures, a development largely explained by the dramatic spending increase among economically advantaged families. In 1990, families in the top quartile of income outspent their bottom quartile counterparts by $\$ 1.11$ per hour of work (\$3.34 versus $\$ 2.23$ ). By 2011 , that gap had grown to $\$ 2.47$ (\$4.93 versus $\$ 2.46$ ). What explains this growing differential? It appears that preferences for certain types of child care have evolved in different ways across low- and high-income families. In results not reported in the tables, I examine participation rates in various child care arrangements separately for children whose mothers have low and high levels of education. Between 1990 and 2011, disadvantaged children became less likely to enroll in the most expensive arrangements - center-based care and nursery school—while their advantaged counterparts remained equally likely to do so. In addition, it is striking that comparisons across low- and high-income families using the same arrangement show a similar divergence in the amount paid for child care.

There are several ways to interpret these results. Insofar as variation in child care expenses explains variation in purchased quality, one interpretation is that the growing income-based gap in child care expenditures means that advantaged children are increasingly exposed to high-quality early care and education experiences - both in absolute terms and relative to their low-income counterparts. ${ }^{13}$ Such an interpretation is consistent with the growing income-based gap in parental monetary (Kornrich \& Furstenberg, 2013; Kaushal et al., 2011) and time (Altintas, 2015; Kalil et al.,

\footnotetext{
${ }^{13}$ Blau's (2001) analysis of child care prices and quality finds a positive, though modest and generally statistically insignificant, relationship. He also finds a weak relationship between prices and quality-related inputs (e.g., group size, teacher-child ratio, and the educational attainment of teachers).
} 
2012; Ramey \& Ramey, 2010) investments in child development. ${ }^{14}$ These large and growing differential inputs are important because of their strong correlation with children's cognitive and socio-emotional outcomes (Bradley et al., 2001; Duncan \& Magnuson, 2011; Conger et al., 2010), and they may explain why the early skills' gap has widened over the past few decades (Reardon, 2011). Such patterns are also consistent with the growing income-based gap in college graduation rates and other adult outcomes (e.g., Bailey \& Dynarsky, 2011). It is a question for future research to confirm whether the increasing gap in families' child care expenses translates into a child care quality gap, and if so, whether that quality gap has implications for developmental and labor market outcomes.

Another interpretation of the growing income-based gap in child care expenditures is that the U.S. child care subsidy system effectively neutralized, for disadvantaged families, the increase in expenses that may have occurred otherwise. Throughout the 1990s, federal and state governments began investing heavily in child care assistance programs aimed at low-income families. The 1988 Family Support Act created the first entitlements through Aid to Families with Dependent Children Child Care and Transitional Child Care. Child care subsidies were expanded again in 1990 through the Child Care and Development Block Grant and the At-Risk Child Care programs. Finally, welfare reform in 1996 consolidated the above-mentioned programs into a single Child Care and Development Fund (CCDF). Together, these reforms increased spending on and enrollments in child care subsidy programs. By 2011, expenditures through the CCDF totaled \$9 billion and served 57 percent poor preschoolers (U.S. DHHS, 2015). Although it is beyond the scope of the current analysis to determine whether these policies explain the flat or falling child care expenses among low-income families, two insights lend support to a potential role. First, Tekin (2005) finds that CCDF child care subsidies induce mothers to switch from informal (e.g., parent) to formal (e.g.,

\footnotetext{
${ }^{14}$ In addition, time use studies find that children of highly educated parents spend less time watching television and more time reading and studying that their less educated counterparts (e.g., Sandberg \& Hofferth, 2005).
} 
center-based) modes of child care. Second, this paper finds that hourly center-based child care expenditures declined among disadvantaged families. It is possible, therefore, that the growing reach and generosity of the subsidy system explains some of this decline.

\section{The Market Price of Child Care}

\section{Introduction and Motivation}

This section examines trends in the market price of child care. This is a useful complement to the previous analysis because changes in families' child care expenditures should reflect in part market dynamics. Unfortunately, direct measures of child care prices are not available at the state- or national-level, so I rely on the earnings of child care workers to proxy market prices. The key insight motivating this approach is that labor costs are the primary input to the production of child care. Indeed, below I present evidence from two data sources showing that the child care industry is unusually labor intensive. Therefore, changes in the price of labor-whether from rising demand for child care, the increased stringency of regulations, or other factors - should be reflected in the market price. These insights suggest that changes over time in child care workers' earnings can serve as a reasonable proxy for changes in the cost of producing child care (Blau, 1992; 2001).

The first piece of evidence comes from the Cost, Quality and Child Outcomes Study (CQCOS), which surveyed parents and assessed preschool-age children attending approximately 400 for- and non-profit child care centers located in four states. To be included in the sample, the centers had to be licensed and provide full-time, year-round services. Survey administrators visited each center in the first half of 1993 to interview the directors or owners about costs and revenues, among other topics. Although the CQCOS is over 20 years old, it is to my knowledge the only survey providing detailed data on the cost structure of a large sample of child care providers. In a technical report for the CQCOS, Morris et al. (1995) conduct an analysis of those costs, and Table 8 presents an adaptation of their results. Specifically, it shows the average monthly cost per child to operate the center, disaggregated by major spending category. Average costs in non-profit centers total $\$ 677$ per 
child, while those in for-profit centers are $\$ 623$ (in constant 2013 dollars). Of the total, labor costs account for $\$ 534$ (or 79 percent) in non-profits and $\$ 385$ (or 62 percent) in for-profits. Total labor costs can be disaggregated into wages and salary as well as non-wage benefits (e.g., health insurance). Wages and salary alone account for nearly 60 percent of all center costs. With the exception of occupancy costs in for-profit centers, it appears that all other categories account for only a small share of centers' operating expenses. ${ }^{15,16}$

The second piece of evidence comes from the Economic Census (EC), which is administered every five years by the U.S. Census Bureau. Establishment-level data are collected on 1,179 six-digit industries within the North American Industry Classification System (NAICS). These fine industry classifications can be aggregated to 317 four-digit industry groups or 100 three-digit subsectors. The primary NAICS child care industry-group is "child day care services" (6244), which is located in the "social assistance" subsector (624). Also included in this subsector are two other labor-intensive human services industries: "individual and family services" (6241) and "vocational rehabilitation services" (6243). Discussed below are data on industry-specific payroll and revenue amounts aggregated to the national level. Specifically, I report the payroll share of revenue for select industries by calculating the ratio of payroll costs to revenue. Although it might be preferable to calculate the labor share of cost, the EC does not collect information on industry costs. Nevertheless, the payroll share of revenue is a widely used substitute for labor share and a reasonable indicator of labor intensiveness (Baumol, 1967; Hall, 1988). I analyze payroll and revenue data from the four EC's administered between 1997 and 2012.

Table 9 summarizes payroll shares for select three- and four-digit industries. Panel A shows a number of industries within the "health care and social assistance" sector, beginning with child day

\footnotetext{
${ }^{15}$ Occupancy costs account for 20 percent of for-profit operating expenses, and only seven percent of non-profit expenses. The difference is explained by the rent or mortgage payments made by the former; it is common for the latter, on the other hand, to occupy donated space.

${ }^{16}$ The importance of staff compensation is corroborated by a set of papers that have used the CQCOS to estimate child care center cost functions, finding that wages are strongly associated with total costs (Blau \& Mocan, 2002; Mocan, 1997).
} 
care services. Although child care payrolls and revenue increased steadily over time, the payroll share of revenue remained fixed at approximately 50 percent. In other words, for every $\$ 1$ of revenue received, about $\$ 0.50$ is used for wages and salary. The remaining rows in Panel A present payroll shares for other labor-intensive industries in the same sector, and in no case does the payroll share exceed that in the child care industry. Panels B and C show several other service-based industries, some of them high-paying (e.g., legal services) and some low-paying (e.g., food services). Panel D presents two additional industries from a mix of service-sectors. The payroll shares in these industries are considerably smaller than that in the child care industry. In analyses not reported in Table 9, I examine several additional industries-including hospitals, ambulatory health care services, retail trade, arts and entertainment, and finance - and I could not find one whose payroll share exceeded the child care industry share. ${ }^{17}$

Together, the analyses above suggest that the child care industry is unique in its reliance on labor in the production process. Such results imply that changes in child care compensation will be reflected in the market price, thereby allowing the earnings of child care workers to be used as time series proxy for prices. The remainder of this section draws on annual data from three high-quality sources to examine child care workers' earnings: Quarterly Census of Employment and Wages (QCEW), Occupational Employment Statistics survey (OES), and Current Population Survey (CPS). Among the key advantages of these datasets are that they provide consistent measures of annual earnings across several industry and occupational categories over a considerable period of time. I describe results from each dataset in turn.

\section{Quarterly Census of Employment and Wages (QCEW)}

Administered by the Bureau of Labor Statistics (BLS) and state Employment Security Agencies, the QCEW is an establishment-level database of employment and wage information for

\footnotetext{
17 The closest industries I found are "vocational rehabilitation services," "accounting, tax preparation, bookkeeping, and payroll services" and "office administrative services."
} 
workers covered by state unemployment insurance (UI) laws as well as the Unemployment Compensation for Federal Employees program. The QCEW is a virtual census of monthly employment and quarterly wages by six-digit NAICS industry code at the national-, state-, and county-levels. Specifically, the public release version of the data includes the number of establishments, monthly employment, and quarterly wages disaggregated by NAICS industry, ownership status, and geographic area. These data can also be expressed as annual averages, and this is the approach taken in the current paper.

The analyses presented below are based primarily on the earnings of workers in the "child day care services" industry between 1990 and 2013. Earnings represent the total compensation paid during the relevant calendar quarter, including that for vacation and other paid leave, bonuses, stock options, tips, the cash value of meals and accommodation, and contributions to retirement plans (e.g., 401(k)). Included in the definition of the child care industry are UI-covered individuals working in the public (e.g., Head Start) or private (e.g., for-profit centers and non-profit churches) sector as well as those in family-based settings. The definition will likely (but not altogether) exclude the earnings of informal caregivers, such as neighbors, relatives, and nannies, as these individuals are not generally UI-covered. It should also be noted that the definition covers workers in a variety of occupations, only one of which is the child care teacher or teacher's assistant. Indeed, included in the earnings measure are the CEOs and managers of national chains, administrative support staff, food preparation and facilities maintenance workers, bus drivers, and many other occupational categories. At the same time, it omits child care workers in other industries, such as elementary and secondary schools and private household services. Therefore, supplementary analyses will examine the earnings trend in these industries.

Figure 2 presents average annual earnings (in constant 2013 dollars) at the national-level for public- and private-sector child care industry employees between 1990 and 2013. Although public sector child care workers earn considerably more than their private sector counterparts, the time trend 
in earnings is remarkably consistent. Both groups experienced a persistent rise in earnings throughout much of the 1990s, followed by flat or falling earnings since the early-2000s. The earnings of public child care workers increased from about $\$ 25,000$ in 1990 to $\$ 31,000$ in 2002 (or 25 percent), but then declined to $\$ 27,000$ between 2002 and 2013 (or 12 percent). As for private child care workers, earnings grew from $\$ 16,000$ to $\$ 20,000$ (or 24 percent) between 1990 and 2004, but remained flat throughout the ensuing decade. Over the entire period, real annual earnings for public child care workers increased 10 percent, while earnings for their private counterparts increased 23 percent.

One advantage of the QCEW is that it permits state-level analyses. Figure 3 presents statespecific trends in private-sector child care earnings between 1990 and 2013. For brevity's sake, it focuses on the private sector since it employs a considerably larger workforce. It treats 1990 as the base year, so that earnings in each subsequent year are displayed as the percent change in compensation (i.e., relative to 1990). The picture emerging from Figure 3 is largely consistent with the national trend: in all but one state (Connecticut), real earnings for child care workers were higher in 2013 than in 1990. In some states (e.g., Washington, Oregon, Utah, and Wyoming), the increase was substantial - at or near 50 percent. Also consistent with the national data is that most of the increase occurred during the 1990s, followed by flat or falling compensation starting in the early2000s. The presentation in Figure 4 makes this clear. It displays state-specific child care earnings separately for two time periods: 1990 to 2004 and 2004 to $2013 .{ }^{18}$ The base year in the former period is 1990, while in the latter it is 2004. Real earnings increased in every state between 1990 and 2004. Since 2004, however, workers in 22 states experienced a reduction in earnings, and for those in states with positive growth, the increase was generally modest (the maximum is 12 percent in Wyoming).

Figures 5 and 6 present national earnings' trends for two industries that employ child care workers, but whose primary function is not child care provision: elementary and secondary schools

\footnotetext{
${ }^{18}$ Given the difficulty in identifying individual states in Figures 3 and 4, Appendix Table 2 presents the percent change in child care workers' earnings across the three time periods analyzed in these figures: 1990 to 2013 (Figure 3), 1990 to 2004 (Figure 4), and 2004 to 2013 (Figure 4).
} 
and private household services. As previously stated, some public schools host pre-kindergarten and Head Start classrooms, and it is common for schools to operate before- and after-school programs to accommodate working parents. Figures 5 reveals that the earnings of public school employees have been essentially flat over the past few decades, while the earnings of private school employees have risen persistently, albeit more slowly after 2004. As for private household services, the nature of the work performed by live-in nannies and babysitters means that they are likely included in this industry category. Figure 6 shows that household service workers witnessed rising earnings throughout most of the 1990s, and flat or falling earnings after 2003.

\section{Occupational Employment Statistics (OES)}

Also administered by the BLS, the OES is a semi-annual mail survey of establishments collecting information on employment and wages across 800 occupations. The survey covers all fulland part-time wage and salary workers in non-farm industries; omitted from the survey are selfemployed individuals, household workers, and unpaid family workers. The OES survey is sent to nearly 200,000 establishments every May and November, with the target sample size of 1.2 million establishments achieved after three years. The survey is designed as a panel, such that a given establishment is contacted once every three years. OES data are available at the national-, state-, and sub-state-levels. The analyses below rely on national data from the May OES surveys fielded between 2002 and 2013, for which consistent occupation and industry codes are available.

A key advantage of the OES survey is that it permits industry-by-occupation estimates of employment and wages. For example, the analyses below present the earnings' trend for several occupational categories within the NAICS child day care services industry. I also present the earnings of those whose occupation is "child care worker" but who are employed outside of the child care industry. This is an improvement over the QCEW because I can examine earnings within and across industries that employ individuals working in a variety of occupations. Earnings in the OES are defined as gross pay, including salary, wages, and tips as well as commissions, incentive and 
hazard pay, and cost-of-living adjustments. The definition excludes overtime and weekend pay, tuition remission, bonuses, and severance payments.

Figures 7 and 8 display the median annual earnings (in constant 2013 dollars) of various NAICS child care industry employees over the period 2002 to 2013. Figure 7 shows the earnings' trend for individuals in pedagogical occupations, while Figure 8 shows the trend for several supportbased occupations. For comparison purposes, both figures present median earnings across all occupations within the child care industry. Looking at Figure 7, it is clear that substantial variation exists in the compensation of individuals in different instructional roles. Kindergarten teachers are compensated at the highest level, followed by preschool teachers and teacher's assistants, and finally child care teachers. Figure 8 reveals a similar story with respect to those working in support occupations. Managers garner relatively high levels of compensation, while those providing food preparation and maintenance services earn considerably less. Nevertheless, it is quite apparent that real earnings across all of these occupations were essentially flat between 2002 and 2013.

Figure 9 presents the annual earnings of those identified as child care teachers employed in industries outside the NAICS-defined child care industry. A few observations are noteworthy. First, compensation levels of child care teachers vary widely across different industries. Those in schoolbased settings earn substantially more than their counterparts in private non-profit settings such as religious and civic organizations. Second, like their counterparts in the child care industry, child care teachers in other settings experienced no real wage growth between 2002 and 2013. In fact, workers in school-based settings witnessed a seven percent reduction in earnings, while those in family services saw a decline of 11 percent.

\section{Current Population Survey (CPS)}

The final set of analyses is based on individual-level data from the March Demographic Supplement to the Current Population Survey (CPS) (King et al., 2010). The CPS is a nationally representative survey of 60,000 to 100,000 households, providing detailed data on labor market 
behavior, income, and demographic characteristics for nearly 200,000 individuals ages 15 and over. March CPS surveys for years 1985 to 2014 are used, yielding information on employment and earnings for the years 1984 to 2013. I include in the sample civilian women ages 18 to 64 . Men are not included because over 95 percent of child care workers are female (author's calculation of the March CPS). I also constrain the sample to individuals who were employed in the previous calendar year, defined as those with non-zero wages and salary or self-employment income. ${ }^{19}$ The resulting sample includes 1,196,669 individuals.

This section examines the annual earnings and hourly wages of three types of early care and education workers: center-based, home-based, and school-based workers. These workers are identified through the CPS's industry and occupation codes attached to the primary job held in the previous year. To construct these mutually exclusive categories, I draw on previous work by Blau (1992), Herzenberg et al. (2005), and Bassock et al. (2013). Center-based workers include non-selfemployed individuals who work in either the "child day care services" industry in any occupation (e.g., "child care workers" or "prekindergarten and kindergarten teachers") except home-based child care occupations (e.g., "family child care providers" or "private household child care workers") or in a child care occupation (i.e., "child care workers") that does not reside in a home- or school-based industry (i.e., "private households," "individual and family services," "family child care homes," or "elementary and secondary schools"). Home-based workers include self-employed individuals working in the "child day care services" industry, those employed in the "family child care homes" industry, those who have early care and education occupations (i.e., "child care workers," "private household child care workers," "prekindergarten and kindergarten teachers," and "early childhood teacher's assistants") within the "private households" or "individual and family services" industries, or those who are self-employed with child care occupations residing in any industry except “elementary and secondary schools." Finally, school-based child care workers are not self-employed

\footnotetext{
${ }^{19}$ I drop those with non-zero hours of work but zero earnings as well as those with non-zero earnings but zero hours of work.
} 
and work in the "elementary and secondary schools" industry with early care and education occupations (i.e., "child care workers," "pre-kindergarten or kindergarten teachers," or "early childhood teacher's assistants"). ${ }^{20}$ Based on these definitions, the sample includes 20,338 centerbased workers, 15,334 home-based workers, and 19,427 school-based workers. The remaining women in the sample $(\mathrm{N}=1,141,570)$ are coded as non-child care workers.

The measure of annual earnings (in the previous calendar year) sums the income received from pre-tax wages, salary, and self-employment. I also construct a measure of hourly wages, defined as total annual earnings divided by the number of hours worked in the previous calendar year. Annual hours is created by multiplying CPS variables for weekly hours of work and annual weeks of work in the previous year. Both variables are adjusted to reflect constant 2013 dollars.

I begin in Figure 10 by presenting median annual earnings of child care workers between 1984 and 2013. For comparison purposes, I also show the earnings' trend for all other female workers. A few observations are noteworthy. First, consistent with the OES results, child care workers in formal settings (e.g., schools) earn more than those in informal settings (i.e., home). Second, all categories of child care workers experienced an increase in real earnings over the past few decades. The rise among home-based workers appears to have been particularly large. Their earnings increased 300 percent over this period, while their school- and center-based counterparts witnessed earnings' growth of 46 and 48 percent, respectively. By comparison, the earnings of all other female workers increased 40 percent, suggesting that child care compensation grew faster than that of the typical worker. Finally, virtually all of the earnings' growth among child care workers occurred prior to the early-2000s. Since 2002, center- and home-based workers experienced flat earnings, and school-based workers experienced slower growth.

\footnotetext{
${ }^{20}$ Some may quibble with the label "school-based child care worker" to describe a group of individuals that includes prekindergarten and kindergarten teachers, in addition to school-based child care workers. Note that this label is for the purpose of ease of discussion only. Given that pre-kindergarten and kindergarten teachers are commingled in the CPS's occupation coding, to include the former in the definition of child care worker (which, I argue, is appropriate) I had to include the latter as well.
} 
It is not clear whether the observed increase in earnings is explained by the rising price of child care labor or by an increase in the intensity of work performed by child care workers. Figure 11 adjusts annual earnings for potential changes in labor supply by displaying the trend in hourly wages. The results suggest that much of the earnings growth observed in Figure 10 is in fact explained by the increasing number of hours worked by child care employees. Hourly wages for school-based workers were essentially flat between 1984 and 2013, increasing only 12 percent; wages for centerbased workers increased 17 percent; and those for home-based workers grew 162 percent. Consistent with the QCEW and OES results, hourly wages grew during the 1990s, peaked in the early-2000s, and were stagnant for at least the next decade. Meanwhile, wages for all other female workers rose 25 percent, indicating that, with the exception of the home-based sector, the price of labor in the child care industry grew more slowly than in other sectors.

\section{Discussion}

This section assessed changes in the market price of child care, using the earnings of child care workers to proxy the time series in prices. The data on earnings were drawn from multiple sources, each one covering a different dimension of the market and containing its own strengths and weaknesses. The QCEW is a census of employment and earnings over a considerable time period, but it permits only a broad assessment of the trend in child care industry earnings. The OES data are available over a shorter time period, but they allow for a more nuanced examination of industry-byoccupation earnings. Finally, the CPS provides the longest time series in earnings; it allows for a fairly nuanced classification of child care workers; and it is the only data source permitting an analysis of hourly wages. However, estimates from the CPS are subject to sampling error, and there are concerns about the quality of self-reported earnings and labor supply.

Nevertheless, the picture emerging from these data sources is strikingly consistent. It appears that the earnings of child care workers grew modestly in real terms over the past few decades. Indeed, the QCEW data suggest that public-sector child care employees witnessed a 10 percent rise 
in earnings, while their private-sector counterparts saw a 23 percent increase. This largely accords with the CPS analysis, which finds that hourly wages grew 12 percent among school-based child care workers and 17 percent among center-based workers. The strong wage growth among home-based workers - 162 percent between 1985 and 2013 - appears to be an aberration, but their wages remain below their counterparts in the formal child care sectors. In addition, these national trends are borne out at the state-level: in all but one state, child care workers' earnings grew in real terms, and in some states the growth was sizeable. Finally, the increase in earnings was largely constrained to the 1990s. Starting in the early-2000s, real earnings stagnated for many child care workers-including those inside and outside of the child care industry as well as those in instructional and support roles_-and declined for others. Again, those in the home-based sector were immune to these market shifts.

Together, the evidence suggests that the market price of child care experienced relatively modest growth in the formal sector (i.e., in center- and school-based settings) and larger growth in the informal sector (i.e., in home-based settings). However, this is a tale of two periods. After increasing steadily throughout the 1990 s, a tentative conclusion is that market prices in most sectors stopped growing in the early-2000s and have not increased in at least a decade. In fact, with the exception of the home-based sector, I find evidence that prices may have fallen in some sectors of the market as well as in a large number of states. It is also noteworthy that the rather unremarkable rise in market prices overall is consistent with the change in families' child care expenditures. Recall from the SIPP analysis in the previous section that median hourly expenditures increased 14 percent between 1990 and 2011 - a magnitude that is not dramatically different from the change in market prices reported in this section.

\section{Supplementary Analyses of the Child Care Market}

To this point, the paper has focused on documenting changes in the cost of child care. It began with a demand-side perspective that analyzed families' expenditures on child care, followed by a supplyside examination of the market price of child care. This section provides a set of auxiliary analyses 
intended to examine various features of the child care market that may have implications for the market price and, ultimately, family expenditures. This section begins by analyzing the demand for non-parental child care, as measured by mothers' labor force participation and children's utilization of formal child care. I then examine changes in the skill level of the child care workforce, followed by an analysis of sectoral choice and the determinants of wages in the child care labor market. Lastly, I explore whether states' child care regulations - in particular staff educational qualifications, staffto-child ratios, and group sizes - have grown more stringent, followed by a reduced form analysis of the effect of regulations on the supply of child care and market prices.

\section{Demand for Child Care}

Given that non-parental child care in the U.S. is utilized primarily by working families, the analysis of child care demand begins by tracking changes in the labor force participation rate of mothers with young children. I draw on March CPS data between 1985 and 2014, and restrict the sample to women ages 25 to 55 who have at least one child ages 0 to 12 . Figure 12 presents the trend in the participation rate separately for mothers whose youngest child is ages 0 to 2 , ages 3 to 5 , and ages 6 to 12. Not surprisingly, mothers with older children are more likely to participate in the labor force than those with younger children. All three groups, however, experienced similar participation trends over the past few decades: rising participation throughout the 1990s, followed by flat or falling participation starting in the early-2000s. For example, the participation rate of mothers with children ages 0 to 2 increased from 52 to 64 percent between 1985 and 2001; since then the participation rate has fluctuated between 60 and 65 percent.

Figure 13 plots separate participation trends for single and married mothers, focusing on those with children ages 0 to 5 . Single mothers entered the labor market in large numbers throughout the 1990s, a phenomenon attributed to the strong economy, the passage of work-based welfare reform in the early- to mid-1990s, and the growing generosity of the Earned Income Tax Credit (Fang \& Keane, 2004; Herbst, 2008). However, after peaking in the early-2000s, single mothers' 
participation rate has been essentially flat for over a decade. The participation rate for married mothers peaked in the mid-1990s, at 65 percent, and it remained at that level over the ensuing two decades.

Perhaps a more direct measure of child care demand is the participation rate in non-parental child care. It is surprisingly difficult to find a consistent time series of child care participation rates, although for a number of years the October CPS implemented a special education supplement in which information on school attendance is ascertained for those ages three and over. Specifically, the survey asks whether individuals are attending or enrolled in regular school, which includes nursery school, preschool, and prekindergarten for three- and four-year-olds. Although the question neglects large swaths of the child care market, it does shed light on the trend in children's participation in center-based early care and education settings. Figure 14 uses the October CPS between 1989 and 2010 to plot this participation rate separately for three- and four-year-olds. Not surprisingly, older children are more likely to utilize formal care than younger children, but the trends are remarkably similar: growing participation rates throughout the 1990s, followed by flat participation beginning in the early-2000s. ${ }^{21}$

\section{Skill Level of the Child Care Workforce}

The analyses below assess changes in the skill level of the child care workforce, where skill is measured by educational attainment. Education is a key input to child care quality, which in turn influences the cost of producing child care services. Therefore, changes in educational attainment could be reflected in the market price of child care. This section begins by sketching a simple model of the child care labor market in order to guide the empirical analysis. It then presents a descriptive portrait of the evolution in child care workers' educational attainment over the period 1992 to 2014.

\footnotetext{
${ }^{21}$ One interpretation of the October CPS data is that it reflects a growing number children switching from parental care to formal non-parental care. Another interpretation is that it reflects a growing number of children switching from informal to formal child care. It is not possible to disentangle these explanations because of the way the CPS variable is constructed. The counterfactual indicates no formal child care attendance, rather than no attendance in any form of non-parental care.
} 
Next, I assess the role of education in the decision to work in various child care sectors. I do so by estimating a reduced form multinomial logit model, where the dependent variable represents various sectoral-choice categories. Finally, I examine sector-specific skill prices by estimating log wage equations as a function of education. The models for sectoral choice and wages are estimated separately on two time periods to determine whether education-based sorting and skill prices have changed over time.

A simple model of the child care labor market, such as that specified in Blau (1992), begins with the assumption that women make utility maximizing choices regarding several labor market categories: (1) center-based child care employment; (2) home-based child care employment; (3) school-based child care employment; (4) non-child care employment; and (5) non-work. Utility is a function of leisure, consumption of goods and services, and child quality. Child quality is determined by maternal and non-maternal time and goods inputs. All women are assumed to have some amount of skill in providing child care, where skill is defined as innate endowments, personality traits, and other qualities developed through human capital investments such as education and training. The price of labor in a particular sector of the labor market, as measured by the hourly wage, is a function of a woman's sector-specific skill and the value placed on skill by employers in that sector. As both increase, so too does the wage of a given woman. In other words, the hourly wage (w) of woman $i$ in sector $j$ is the product of the quantity of skill $(\pi)$ and the skill price $(\mathrm{z}), \mathrm{w}_{i j}=\pi_{i j} \mathrm{z}_{i j}$. In this model, one can interpret the hourly wage rate as the market price of quality, with educational attainment specified as an observable input to quality. Experience, as measured by a woman's age, is also likely to be an observable input captured by $\pi$. It is predicted that the price of quality is increasing in these and other inputs, with the precise magnitudes of the skill prices likely to vary across different child care sectors and between the child care and non-child care sectors.

To set the stage for the sectoral choice and wage analysis, I begin by presenting trends in educational attainment for center- (Figure 15), home- (Figure 16), and school-based (Figure 17) child 
care workers. This analysis relies on the March CPS and uses the same classification of child care workers described in Section III. The top panel of each graph displays the fraction of child care workers with a high school degree or less, some college education but no degree, and a college degree or more. The bottom panel shows the annual percentage point difference in the fraction with a college degree between child care workers and all other female workers. Thus negative values on the bar graph indicate that child care workers are less likely to have a college degree. The comparison focuses on those with a college degree because the returns to education are likely to be relatively large at this level.

As revealed in the top panel of each figure, there have been noticeable improvements in the skill level of child care workers, particularly at the low-end of the skill distribution. The share of workers with a high school degree or less declined sharply between 1992 and 2014. School- and home-based child care workers witnessed the largest declines (from 40 to 19 percent and from 68 to 37 percent, respectively), followed by center-based workers (from 47 to 36 percent). To replace these low-skilled workers, the home-based sector witnessed about equal growth in the share with some college education (from 23 to 45 percent) and with a college degree or more (from nine to 18 percent). On the other hand, the declining number of low-skilled workers in the center- and schoolbased sectors was offset largely by an increase in those with some college education. Indeed, these child care sectors witnessed relatively modest growth in the fraction of the workforce with a college degree. Notwithstanding these skill improvements, the child care industry continues to be dominated by workers lacking a college education. As of 2014, 75 percent of center-based workers, 82 percent of home-based workers, and 59 percent of school-based workers had not obtained a college degree.

Although the skill level of child care workers increased in absolute terms, the bottom panel of each figure reveals that such workers may have actually lost ground relative to their non-child care counterparts. The relative decline in skill attainment is particularly evident for center-based workers, who were about five percentage points less likely to a have college degree in the early-1990s. By 
2014, the college gap increased to 12 percentage points. School-based workers in the early-1990s were eight percentage points more likely to have completed college, a surplus that was reduced to about four percentage points by 2014. It appears that workers in the home-based sector are the only ones who did not experience a relative decline in skill attainment. However, a large deficit in college completion—nearly 20 percentage points lower than non-child care workers—persisted as of 2014.

To gain a deeper understanding of the role of education in women's employment decisions, I now turn to the multinomial logit model of sectoral choice. I rely once again on the pooled March CPS surveys between 1992 and 2014, providing labor market information between 1991 and 2013. I retain civilian women ages 18 to 64 regardless of employment status. Stated formally, the likelihood that woman $i$ in year $t$ chooses the $j$ th employment sector is modeled in the following manner:

[1] $\quad \operatorname{Pr}\left(y=j \mid \mathbf{x}_{i t}\right)=\frac{\exp \left(\alpha+\mathbf{Z}^{\prime} \beta\right)}{\sum_{j=1}^{J} \exp \left(\alpha+\mathbf{Z}^{\prime} \beta\right)}$

in which there are five sectoral choice categories: (1) center-based child care sector; (2) home-based child care sector; (3) school-based child care sector; (4) all non-child care sectors; and (5) non-work. Estimates are interpreted in relation to category (5), women who are not employed. The $\mathbf{Z}^{\prime}$ is modeled in the following manner:

[2] $\quad \mathbf{Z}^{\prime} \beta=\mathbf{X}^{\prime} \psi+$ speriod $_{t}$

where the $\mathbf{X}^{\prime}$ is a vector of demographic characteristics, in particular a set of three dummy variables for educational attainment: high school degree, some college education but no degree, and a college degree or more. The full list of demographic controls is included in the notes to Table 10. Appendix Table 3 provides summary statistics for the subset of women in each employment sector. The model includes a set of year-specific effects, denoted by period. I also experiment with models that include state fixed effects, and the results are similar to those reported here. The model outlined in [1] and [2] is estimated separately on two time periods - 1991 to 2001 and 2002 to 2013 - to determine whether 
education-based sorting into various employment sectors intensified over time. These time periods represent not only an even split (nearly) of the full period, but they approximate the distinct periods in which market prices increased and then stagnated.

Table 10 displays the marginal effects and standard errors (shown in parentheses) for the mulitnomial logit model. The marginal effects are evaluated at the variable means, and the standard errors are adjusted for within-year clustering. The first set of results covers the period 1991 to 2001, while the second set covers the period 2002 to 2013. A few findings are noteworthy. First, education has a positive effect on the likelihood that a woman will choose employment in the center- and school-based sectors (compared to non-work). Conversely, education has a negative impact on the likelihood of choosing employment in the home-based sector. In other words, highly educated women find non-work more attractive than home-based child care employment. This pattern is similar to that reported in Blau (1992), who estimates a comparable sectoral choice model covering an earlier period (1976 to 1986). Second, a comparison of the education coefficients across both time periods reveals that child care's attractiveness to highly-skilled women generally did not increase over time. In fact, it appears that women with a college degree became less likely to choose centerand school-based child care employment. ${ }^{22}$ Only in the home-based sector did highly-skilled women become more likely to choose child care employment. Finally, looking at the non-child care sector, education has a positive impact on the probability of choosing work over non-work. Furthermore, employment in non-child care occupations became more attractive over time for women at the highest skill level (i.e., those with a college degree).

The final analysis in this section examines skill prices in the child care labor market, where skill is once again defined by educational attainment. I do so by estimating sector-specific regressions of $\log$ hourly wages on education, controlling for a variety of demographic

\footnotetext{
${ }^{22}$ In results not reported in the paper, I estimate the sectoral choice model in five or six year increments of the CPS (as opposed to the two-period split shown in Table 10). The negative education-based sorting of center- and school-based child care workers becomes more evident when finer time periods are examined.
} 
characteristics. Using pooled March CPS surveys between 1992 and 2014, the wage equation is specified as:

$$
\ln \left(w_{\mathrm{ijt}}\right)=\alpha_{\mathrm{o}}+\mathbf{X}^{\prime} \beta+\mathbf{Z}^{\prime} \gamma+\text { period }_{\mathrm{t}}+\varepsilon_{\mathrm{ijt}}
$$

where $\ln (w)$ is the log hourly wage for woman $i$ participating in sector $j$ in year $t$. The sectors are the same as those examined in the multinomial logit model. The $\mathbf{X}^{\prime}$ is a set of three dummy variables for educational attainment, as defined above. The $\mathbf{Z}^{\prime}$ denotes a number of demographic characteristics that may also signal worker skill or quality. These variables are identical to those found in the sectoral choice model described above, with the exception of family size and non-wage income. Finally, the model includes a set of year-specific effects, denoted by period, to capture any unobserved time-varying factors that are related to education and wages. As was done in the sectoral choice model, I experiment with state fixed effects, and the results are quite similar to those reported here. In addition, the model is estimated separately on two periods - 1991 to 2001 and 2002 to 2013 - to allow for temporal differences to emerge in the price of skill.

The estimation of sector-specific wage equations must overcome the potential self-selection of women into the labor market as well as the sorting of women into different occupational sectors. In other words, I observe the wage in a given sector for women who have selected into that sector. I do not observe, for example, the wages that center-based workers would have earned had they chosen to work in the home-based sector, and vice versa. If unobserved characteristics that affect work and sector choices are also correlated with productivity, then a form a sample selection bias will render the coefficients on education inconsistent. To ensure consistent estimates, a reduced form model of sectoral choice is estimated using a multinomial logit model, and whose results are used to construct a set of sample selection terms for inclusion in the wage equations. The multinomial logit model is identical to the one estimated above, and I use family size, a quadratic in family size, and real nonwage income as exclusion restrictions. Similar variables were used in previous analyses of the child care labor market (Blau, 1992; 1993). The equations for sectoral choice and hourly wages are 
estimated jointly using the procedure developed by Bourguignon et al. (2007) for contexts in which the sample selection process is modelled as a multinomial choice. The model for sectoral choice is estimated on the full sample of women, and the wage equations are estimated separately on the subsets of women employed in each sector, with the sample selection terms included as controls. The sample selection terms are generated using the Dubin and McFadden (1984) method, which allows for separate correlations between the sector-specific disturbance terms.

Estimates from the selection-corrected wage equations are presented in Table 11. Panel A shows the estimates for the period 1991 to 2001, and Panel B shows the analogous results for the period 2002 to 2013. Child care workers in all sectors receive positive returns to education. However, there are some important differences across sectors and time periods. Center- and school-based child care workers witness greater returns to education than their home-based counterparts. The relative effect of education seems to be particularly large for center- and school-based workers at the top of the skill distribution (i.e., those with a college degree). Furthermore, a comparison of the education coefficients in Panels A and B reveals that skill prices have changed over time in different ways across various child care sectors. Center-based workers experienced declining (positive) returns to education; home-based workers experienced modest increases; and school-based workers witnessed large increases. As shown in the final column, non-child care workers experienced sizeable growth over time in the returns to education. These patterns suggest that while other labor markets increasingly value education, this may not be the case within some sectors of the child care market.

In results not reported in the table, I find that age - a proxy for work experience- has a smaller positive effect on wages among child care workers than among non-child care workers. In addition, the effect of age declined over time for center- and home-based workers, but it increased somewhat for school-based workers. The declining effect of work experience for women in the center-based sector is striking in light of the decreasing returns to education noted above. Black child care workers in all sectors earn more than their white counterparts; the reverse is true among non- 
child care workers. There are also regional differences in wages, with workers in all sectors estimated to earn less if they reside in the South. Interestingly, this Southern wage penalty is substantially larger in the child care sector than it is in the non-child care sector.

\section{Child Care Regulations}

In this section, I examine a number of labor-related regulations that may have implications for the cost of providing child care. Such an analysis is important because some observers have suggested that the growing stringency of states' regulations is at least partially responsible for the rise in child care costs. This section begins with a brief description of and the rationale for child care regulations, followed by a simple theoretical model of the impact of regulations on the child care market. I then provide descriptive evidence on changes over time in the stringency of a few key regulations in the center-based market. This section ends with a reduced form analysis of the impact of regulations on outcomes in the child care market, including the supply of child care, child care employment decisions, and earnings.

The overarching goal of child care regulations is to minimize the risk of harm to young children from exposure to low-quality care. Such risks include injury, illness, and developmental damage. Regulations establish a minimum level of quality in the market, as opposed to achieving the socially optimal level. It is therefore possible for a given child care provider to comply with all regulations, but nevertheless offer developmentally inappropriate services. Regulations are set at the state-level, and they cover virtually all dimensions of the child care environment, including maximum group size; child-to-staff ratios; the age, experience and educational attainment of directors and teachers; immunizations; food safety; physical features of the provider; among other items. However, there is substantial variation across states in whether and to what extent a given feature is regulated. In addition, the stringency of regulations often varies by the age of children served and across center- and home-based providers. Those failing to meet regulations, as determined by the state licensing agency, may be fined or denied an operating license. 
The primary economic rationale for child care regulations is to deal with information problems in the market (Blau, 2001). Child care quality comprises a complex and multidimensional set of characteristics that parents often cannot fully assess, either because of cognitive limitations or insufficient access to information. In addition, there may be negative externalities - in the form of lower lifetime earnings, greater use of cash assistance, and higher crimes rates - if children are exposed to low-quality or dangerous environments. To deal with these market problems, child care regulations may ensure, even for poorly informed parents and their children, that providers meet a minimum level of quality. One way this is achieved is by removing from the market all child care providers that would operate if the regulatory structure was not in place.

Assuming that child care regulations are binding and enforced, economic models make several predictions regarding the effect of tougher regulations on the child care market (Blau, 2003). First, more stringent regulations will decrease the supply of and demand for licensed child care. Consumers are predicted to respond to tougher regulations by shifting demand to more lightly regulated sectors or to the underground child care market in which regulations are nonexistent. If this occurs, then results from the empirical analysis below should show a negative effect of regulations on child care labor supply. Second, tougher regulations have a theoretically ambiguous effect on the market price of child care. On the one hand, a declining supply of formal child care, coupled with decreasing demand for child care labor, means that wages and prices will decline. Conversely, many regulations are likely to be quite costly for providers, thereby leading to increased market prices. Depending on which dynamic dominates, the forthcoming empirical analysis may find a positive or negative effect of regulations on wages. Third, tougher regulations are predicted to increase child care quality. Improvements can be achieved either by eliminating low-quality providers from the market or inducing providers to comply with the regulations. As a result, it is possible that the demand for licensed child care may increase if parents recognize and value the quality enhancements. 
If regulations are not binding or strictly enforced, they are not likely to influence outcomes in the child care market. It is not clear to what extent providers currently face binding regulations, but generally speaking as this number declines so too will the impact of regulations. Evidence discussed in Blau $(2001 ; 2003)$ indicates that states' enforcement budgets are not large, and, as a result, providers are not inspected frequently. Therefore, it is possible that many providers operate for long periods while in non-compliance. Perhaps the best evidence on these issues comes from Blau's (2001) analysis of the CQCOS. He examines group sizes and staff-to-child ratios in 400 child care centers across four states, and compares the rosters provided by each center to the state regulation in each domain. Blau's results suggest that regulations are binding on a small fraction of centers because most exceed the regulated standards. Of those faced with binding regulations, rates of noncompliance are high. Specifically, only 20 to 30 percent of providers face binding regulations, and over half of those are out of compliance with either requirement.

Using the CPS between 1991 and 2010, I provide additional evidence on the extent to which regulations might be binding. Specifically, I compare the educational attainment of center-based child care workers to the state-specific requirement for teachers' education level. I then calculate the share of center-based workers in each of four categories: employed in a state without an education requirement (17.1 percent); resides below the mandated education threshold (16.7 percent); resides at the threshold (29.0 percent); and resides above the threshold (37.2 percent). Consistent with Blau (2001), it appears that a non-trivial share of center-based workers exceed the regulated standard for educational attainment. In addition, the share of workers exceeding the threshold increased from 36.4 to 40.4 percent between 1991-92 and 2009-10. Together, the evidence suggests that regulations are not binding on large numbers of providers, and as a result they are predicted to have only a modest effect on child care supply and prices.

The analyses below are based on child care regulation data compiled by Dapha Bassok and colleagues, covering the period 1990 to 2010. I also make use of another regulation database 
constructed by V. Joseph Hotz and Rebecca Kilburn, which covers the period 1983 to $2000 .^{23}$ These datasets include state-by-year regulations covering a large number of domains. I begin by providing descriptive evidence on changes in the stringency of a few labor-related regulations over time. The analysis is constrained to center-based regulations, as these data are more complete than the coverage for family-based providers. As shown in Table 12, the top panel examines requirements for directors' and teachers' educational attainment as well as child-to-staff ratios for two- and four-year-olds. Information on these rules is available between 1990 and 2010. The bottom panel explores maximum group size regulations by child's age over the period 1983 to 2000. I present summary statistics for each regulation in the first and last year of the relevant dataset across a consistent set of states. ${ }^{24} \mathrm{I}$ also use the full time period available in the datasets to estimate regressions of each regulation on a linear time trend. ${ }^{25}$

Looking at the top panel of Table 12, a mixed picture emerges regarding the changing stringency of states' child care regulations. On the one hand, a smaller number of states in 2010 did not regulate center directors' education (1990: six states; 2010: two states) and teachers' education (1990: 16 states; 2010: 12 states). However, there was an increase in the number of states mandating the lowest level of education (a high school degree), and a decrease in the number of states mandating higher levels of education (associate's or bachelor's degree). The final column in Table 12 uses the full set of years in the data to estimate the time trend in education mandates. I find that states' education mandates for directors became less strict between 1990 and 2010, while the mandates for teachers become stricter. The regressions reveal a similarly mixed story for the child-to-

\footnotetext{
${ }^{23}$ The Bassok database is an amalgamation of information originally collected by Hotz and Kilburn and more recent information collected by the Bassok team. These data are used in Bassok et al. (2013) to analyze the extent of between and within sector quality.

${ }^{24}$ Therefore, the number of states varies in the analysis of each regulation. A total of 45 states are included in the analysis of 1990 and 2010 director education; 47 states are included in the analysis of teacher education; 48 states are in the analysis of twoyear-old ratios; and 50 states are in the analysis of four-year-old ratios. A total of 46 states, 46 states, 47 states, 46 states, 46 states, and 46 states, respectively, are included in the analysis of 1983 and 2000 maximum group size.

${ }^{25}$ Again, the number of states varies from year-to-year, so that the regression analysis is conducted on the unbalanced panel of states.
} 
staff ratios: those applied to two-year-olds became stricter over time, while those applied to fouryear-olds became more lenient.

The bottom panel of Table 12 subjects states' maximum group size regulations to the same set of tests. Recall that I analyze separate single-year-of-age regulations for children ages 0 to 5 in center-based environments. Here, the results are more consistent. On the one hand, a larger number of states in 2000 (the most recent year) regulated group sizes in child care centers. However, conditional on stipulating a regulation, the mean maximum group size increased in all but one age group. Results from the time trend regressions confirm that regulated group sizes increased between 1983 and 2000, indicating that states' regulations in this dimension became more lenient.

I now proceed to the analysis of the effect of child care regulations on child care supply, employment, and earnings. The analysis is based on two datasets: a panel of states between 1990 and 2010 using the QCEW, and pooled CPS cross-sections between 1992 and 2011. As discussed in Section III, the QCEW is an establishment-level database of employment and wage information for UI-covered workers in all six-digit NAICS industries. I limit the dataset to annual, state-level information on the number of establishments, total employment, and weekly earnings for the private "child day care services" industry. I merge to the QCEW state-level information on center-based child care regulations collected by Dapha Bassok and colleagues. Thus I have a dataset of 1,071 state-year combinations, with which I estimate regressions of the following form:

[4] $\quad \ln \left(e_{\mathrm{st}}\right)=\alpha_{\mathrm{o}}+\mathbf{X}^{\prime} \beta+\mathbf{Z}^{\prime} \gamma+$ speriod $_{\mathrm{t}}+\eta$ state $_{\mathrm{s}}+\varepsilon_{\mathrm{st}}$

where $e$ represents the log of some employment outcome in state $s$ and year $t$. Specifically, I examine the number of child care establishments per capita, total child care employment per capita, and average weekly earnings. The $\mathbf{X}^{\prime}$ is a set of child care regulations pertaining to directors' and teachers' educational attainment and child-to-staff ratios for two- and four-year-olds. ${ }^{26}$ The $\mathbf{Z}$ ' is a set

\footnotetext{
${ }^{26}$ As stated above, the individual child care regulation variables are missing in different states for different years, leading to an unbalanced panel. I create a balanced panel by imputing values for the missing regulation data and including dummy variables
} 
of observable state characteristics, including per capita income, the unemployment rate, population density, the fraction voting Republican in the last Presidential election, and the fraction with at least a college degree. The model includes a set of year-specific effects and state fixed effects, denoted by period and state, to control for unobserved time-varying and time-invariant characteristics that are correlated with the employment outcomes. All regressions are weighted by the state population, and the standard errors are adjusted for within-state clustering.

The first three columns in Table 13 show the coefficient and standard error (in parentheses) on each regulation in ordinary least squares (OLS) regressions of child care establishments, employment, and weekly earnings, respectively. The education regulations are treated as a set of dummy variables, using states without the relevant regulation as the omitted category. The child-tostaff ratios are treated as continuous variables. I find that increasing the regulatory stringency of directors' education reduces the supply of child care. For example, states that require directors to have a college degree witness a 26 percent reduction in the number of establishments and an 18 percent reduction in employment. In addition, requiring more education for directors reduces market prices by 4.5 percent, as indicated by the (mostly) negative coefficients in the earnings regression. The one exception is the requirement for directors to have a college degree, which has a small positive effect on prices. On the other hand, requirements for teachers' education are associated with increases in child care supply and prices, with one exception. States requiring teachers to have a college degree witness a reduction in supply. Looking at the child-to-staff ratios, stricter requirements for two-year-olds lead to reductions in supply, but have no effect on prices. Those directed at four-year-olds do not affect supply or prices.

for the missing values in the regression. In addition, a concern with the child care regulations is the potential multicollinearity introduced by including all variables at the same time. The two most highly correlated regulation variables are those for the twoand four-year old child-to-staff ratios (0.67). The correlation for directors' and teachers' educational attainment is 0.43 (when they are treated as continuous variables). The remaining correlations are below this. Thus there appears to be sufficient independent variation in each regulation so as to mitigate the influence of multicollinearity. 
Analysis of the CPS uses data on employment over the period 1991 to 2010. The sample includes civilian women ages 18 to 64 regardless of employment status. I merge to the CPS microdata the same state-level child care regulations described above. The sample includes 1,115,373 observations. The outcome is the probability of employment in the center-based child care sector, which is modelled using a multinomial logit model similar to that specified in equations [2] and [3]. However, the outcome contains three sectoral choice categories instead of five: (1) center-based child care sector; (2) all other sectors; and (3) non-work. Estimates are interpreted in relation to category (3), women who are not employed. For brevity's sake, I only show the estimates for center-based employment. The demographic controls are identical to those described in equation [2], except that Southern state residence is excluded. The model includes a set of year-specific effects and state fixed effects. All standard errors are adjusted for within-state clustering.

Although it is of interest to study the effect of regulations on hourly wages, there are too few observations on center-based workers $(15,064)$ to support an analysis that includes state fixed effects. Fixed effects are important for handling the potential policy endogeneity of child care regulations, but in such a model there is insufficient data (as well as within-state over-time variation in regulations) for generating statistically precise estimates. Therefore, I do not present estimates from a fixed effects wage equation. Instead, I discuss estimates from a wage equation that includes regionspecific indicators, with the caveat that the region effects may not fully control for unobserved statelevel determinants of wages.

The final column in Table 13 presents the marginal effects (evaluated at the variable means) on the center-based child care regulations in the multinomial sectoral choice model. It is reassuring that the pattern of results is quite similar to those for child care supply in the first two columns. Increasing the stringency of regulations targeting directors' education lowers the odds a woman will be employed in the center-based child care sector. Regulations aimed at teachers' education, on the other hand, do not appear to influence employment decisions. In terms of child-to-staff ratios, stricter 
requirements for two-years-olds reduce the probability of child care employment, while those directed at four-year-old do not affect employment decisions. As for the wage equation, very few of the individual coefficients are statistically significant or even approaching significance, and there is no clear pattern in the signs of the coefficients. The only statistically significant result is the negative effect on prices of the teacher mandate to have a college degree. This is the opposite sign from its counterpart in the QCEW analysis, so it is unclear how it should be interpreted. The coefficient on the staff-to-child ratio for two-year-olds is positively signed $(\mathrm{t}=1.33)$ — consistent with its counterpart in the QCEW analysis - and it implies a 0.5 percent increase in wages for each one-unit increase in the ratio. The coefficient on the four-year-old ratio is negatively signed $(t=1.22)$, which is inconsistent with its counterpart in the QCEW.

\section{Interpretation}

The goal of this section was to assess several features of the child care market that may shed light on the evolution of prices and family expenditures. First, I analyzed the demand for nonparental child care. Second, I examined the skill level of the child care workforce, followed by a formal empirical analysis of the effect of skill on child care employment and prices. Finally, I assessed whether states' child care regulatory structure increased in stringency, and conducted an analysis of the effect of regulations on the supply of child care labor and market prices. Below I summarize the main results from each analysis, paying careful attention to how they inform the observed trends in family expenditures and market prices presented in Sections II and III.

The time trend in mothers' labor force participation and children's child care utilization point to a consistent story about the demand for child care over the past few decades. Child care demand likely increased throughout the 1990s as mothers' labor force participation increased. This is broadly corroborated by the growing use of formal child care among three- and four-year-olds. However, both participation rates peaked around the same time, in the early-2000s, after which no further increases are observed. A tentative conclusion, therefore, is that child care demand has been stagnant 
for over a decade. These demand-side trends are remarkably consistent with the time trend in child care workers' earnings described in Section III. That the flattening of child care compensation occurred contemporaneously with the flattening of labor force participation and child care utilization suggests that the market price of child care is responding in predicable ways to changes in demand. Of course, it is possible that mothers' labor supply is instead responding to the market price of child care, such that the flattening of labor force participation is explained by rising child care costs. However, estimates of the elasticity of labor supply with respect to child care prices indicate that mothers are only moderately sensitive to child care prices (e.g., Herbst, 2010). Thus it is unlikely that changes in market prices substantially explain the trend in mothers' labor force participation.

Nevertheless, it is not certain that had labor force participation continued to grow, the market price of child care would have increased commensurately. Previous research shows that the supply of child care labor is highly elastic, suggesting that as the demand for child care increases, providers are able to increase supply without raising prices. Indeed, Blau's (1993) analysis of the child care labor market in the late-1970s and 1980s estimated supply elasticities in the range of 1.2 to 1.9 . It is noteworthy that mothers' labor force participation grew during this period, but hourly wages for child care workers were stagnant (Blau, 1992). To explain these elasticities, Blau (1993) postulates that child care is a relatively low-barrier occupation to enter, and that states' regulatory regimes are not so strict as to deter individuals from seeking child care employment. It is beyond the scope of this paper to generate updated supply elasticities, and this is left as an important exercise for future research.

The analysis of child care workers' educational attainment indicates that the workforce became more skilled in absolute terms over the past few decades. Today a substantially smaller share of child care workers has a high school degree or less. These low-skilled workers have been replaced primarily by those with some post-secondary education, and to a lesser extent those with a bachelor's degree. Workers in the home-based sector have made the largest strides in educational attainment, but they continue to lag behind their center- and school-based counterparts, especially in college degree 
attainment. Historically, child care workers have been less-skilled than other female workers, and I provide evidence that the skill gap may have increased over time. Indeed, the gap in college completion grew substantially for center-based workers, while the sizable edge once held by schoolbased workers was reduced by half. Home-based workers are the only ones who did not experience a relative reduction in educational attainment.

These descriptive trends are largely borne out by the formal empirical analysis. Although education is positively correlated with employment in the center- and school-based sectors, the degree to which higher-skilled women are drawn to child care employment has declined over time. As the supply of high-skilled center-based labor has fallen, so too have the returns to education. Indeed, I find that college-educated center-based workers today experience a smaller wage premium than their counterparts from several decades ago. Moreover, I find that education is actually negatively correlated with employment in the home-based sector, although this negative correlation has attenuated over time. My overarching conclusion is that the child care industry has not become more attractive to women with higher levels of education.

Changes in the skill level within various child care sectors largely mirrors the evolution of prices in the respective sectors. Home-based workers experienced relatively large increases in educational attainment and, in turn, hourly wages. Moreover, the increase in wages persisted through the early-2000s, when the wages of other workers began to stagnate. Center-based workers, on the other hand, experienced the smallest improvement in education and only modest increases in wages. In addition, center-based employment became less attractive to high-skilled women, and the returns to education declined for these workers. The situation in the school-based sector represents an anomaly. On the one hand, this sector saw large improvements in the skill-level of its workforce, and large increases in the returns to education. However, hourly wages increased only slightly for these workers. It is worth noting that the definition of school-based child care workers includes kindergarten and pre-kindergarten teachers in addition to child care workers located in elementary 
and secondary schools. It is less likely that wages in this sector are a good proxy for prices, since education in public schools is provided free-of- charge. This may also apply to before- and afterschool child care programs provided in schools. In addition, education levels have been historically (relatively) high in this sector, due in large part to states' education requirements for teachers. Therefore, it is possible that skill levels increased without a commensurate rise in compensation. Finally, wage-setting in the school-based sector is determined in part by contractual agreements with education unions, indicating that wages are less responsive to changes in demand or skill prices.

In the last set of analyses, I study states' child care regulatory regimes. Although a large number of domains are regulated in center- and home-based child care settings, I constrain the analysis to a small set of center-based mandates related to the skill attainment of workers, staff-tochild ratios, and maximum group sizes. Changes in these requirements are likely to have the greatest impact on market prices because they are directed at workers - the most important input to the production of child care. It appears that states have become less strict in some areas and stricter in others. Requirements for directors' education, ratios for older children, and group sizes for children of all ages have grown in leniency; those for teachers' education and ratios for younger children have grown in stringency. The diverging trends could be a reflection of shifting priorities by states, or an awareness of the potential increase in provider costs when regulations are tightened in one area. Nevertheless, there is little evidence that regulations writ large are more stringent, nor do I find that tightening regulations is consistently associated with higher prices. My empirical results accord with some previous work (e.g., Blau 2001; 2003), but are at odds with other work (e.g., Hotz \& Kilburn, 1994; Hotz \& Xiao, 2011). A tentative conclusion, however, is that regulations likely have only a small effect on the child care market in the sense that they are not primarily responsible for rising or falling market prices. That regulations do not appear to be binding for most providers and that regulatory stringency is actually falling in some domains lends support to this conclusion. 


\section{Conclusion}

This paper began with a seemingly simple question: has the cost of child care in the U.S. increased over time, as policymakers and analysts seem to suggest? From a scholarly perspective, this question is of first-order importance because the direction and magnitude of the change in child care costs often inform theoretical models of the labor and child care markets. Policymakers require highquality information on child care because they are on the front line in the debate over such issues as families' work-life balance and the role of the state in providing non-parental care. In addition, policymakers have the power of the purse strings. Indeed, recent years have witnessed a flurry of legislative activity in response to the purported rise in the cost of child care.

Despite its importance, virtually no scholarly attention has focused on whether, or by how much, the cost of child care has increased over the past few decades. This paper finds that expenditures on child care by the typical family have not increased nearly as much as previously estimated. However, the story is quite complicated. Low-income families generally spend the same amount or less on child care, while high-income families spend considerably more. In addition, payments to informal providers such as grandparents have declined, while those to formal providers such as nursery schools have increased. Despite these diverging trends, the typical family today allocates as much income to child care as it did in the early-1990s. When the market price of child care is considered, I find that prices increased modestly in most sectors throughout the 1990s - in response to the rising demand for child care-but have been essentially flat since the early-2000s. A tentative conclusion is that, with the exception of home-based services, the market price of child care has not increased in over a decade.

Insights from the analysis of the labor and child care markets are in broad agreement with this conclusion. Mother's labor force participation and children's utilization of formal care levelled off in the early-2000s, at the same time the rise in market prices was halted. Although the child care workforce is more skilled today than it was several decades ago, it remains the case that child care 
employment is relatively unattractive to women with high levels of education. This provides a partial explanation for why the market price of child care did not increase more than has been documented here. Finally, I find that child care regulations are not likely to be binding on large numbers of providers; they have not systemically increased in stringency; and they do not appear to have a large effect on prices. Thus states' regulatory regimes do not loom large enough to substantially drive market prices up or down.

Although the share of medium- and high-income families paying for child care has declined over time, it remains the case that more of these families use paid care than their low-income counterparts. In addition, conditional on paying, expenditures by higher-income families increased rapidly, while expenditures for some low-income families actually fell in real terms. To the extent that the child care subsidy system - in particular, the means-tested CCDF-is responsible for this decrease among low-income families, it suggests that a more comprehensive system of financial assistance may be warranted. One solution is to create a subsidy system whose eligibility is not conditioned on parental employment or family income, but whose benefits are a decreasing function of family income and an increasing function of child care quality. In other words, it may be socially optimal to have a universal system - open to families regardless of employment status and income level - that nevertheless targets benefits at disadvantaged families and provides strong incentives to purchase high-quality services.

Increasing the demand for quality should have the effect of increasing the demand for higherskilled workers, thereby making the child care sector more attractive to those with advanced levels of education. A system of universal subsidies may also catalyze broad increases parental labor force participation, which has been essentially flat for over decade. Results from the policy experiment in Quebec, Canada, which enacted universal child care in the late-1990s, are instructive: maternal employment increased; the use of cash assistance decreased; and the system, while costly, paid for itself through higher tax revenues and GDP and lower social expenditures (Fortin et al., 2012). 


\section{References}

Altintas, E. (2015). Widening education-gap in developmental childcare activities in the U.S. Journal of Marriage and Family. Forthcoming.

Anderson, P., \& Levine, P. (2000). Child care and mothers' employment decisions. In R. M. Blank \& D. Card (Eds.), Finding jobs: Work and welfare reform. New York, NY: Russell Sage Foundation.

Bailey, M. \& Dynarski, S. (2011). Inequality in Postsecondary Education. In Whither Opportunity: Rising Inequality, Schools, and Children's Life Chances, ed. Greg J. Duncan and Richard J. Murnane, 117-132. New York: Russell Sage Foundation.

Bassok, D., Fitzpatrick, M., Greenberg, E., Loeb, S. (2013). The extent of within- and between-sector quality differences in early childhood education and care. Working Paper No. 17. Center on Education Policy and Workforce Competitiveness, University of Virginia.

Bassok, D., Fitzpatrick, M., Loeb, S. \& Paglayan, A. (2013). The early childhood care and education workforce from 1990 through 2010: Changing dynamics and persistent concerns. Education Finance and Policy, 8, 581-601.

Baumol, W. (1967). Macroeconomics of unbalanced growth: The anatomy of urban crisis. American Economic Review, 57, 415-426.

Blau, D. (1992). The child care labor market. Journal of Human Resources, 27, 9-39.

Blau, D. (1993). The supply of child care labor. Journal of Labor Economics, 11, 324-347.

Blau, D. (2001). The child care problem: An economic analysis. New York, NY: Russell Sage Foundation.

Blau, D. (2003). Do child care regulations affect child care and labor markets? Journal of Policy Analysis and Management, 22, 443-465.

Blau, D. \& Mocan, N. (2002). The supply of quality in child care centers. Review of Economics and Statistics, 84, 483-496.

Bourguignon, F., Fournier M. \& Gurgand M. (2007). Selection bias corrections based on the multinomial logit model: Monte carlo comparisons. Journal of Economic Surveys, 21,174-205.

Bradley, R. H., Corwyn, R. F., Burchinal, M., McAdoo, H. P., \& Garcia Coll, C. (2001). The home environments of children in the United States. Part 2: Relations with behavioral development through age 13. Child Development, 72, 1868-1886.

Child Care Aware of America. (2014). Parents and the High Cost of Child Care: 2014 Report. Arlington, VA: Child Care Aware of America.

Conger, R., Conger, K., \& Martin, M. (2010). Socioeconomic status, family processes, and individual development. Journal of Marriage and Family, 72, 685-704. 
Connelly, R., \& Kimmel, J. (2003a). The effect of child care costs on the employment and welfare recipiency of single mothers. Southern Economic Journal, 69, 498-519.

Connelly, R., \& Kimmel, J. (2003b). Marital status and full-time/part-time work status in child care choices. Applied Economics, 35, 761-777.

Dubin, J. A. \& McFadden, D. L. (1984). An econometric analysis of residential electronic appliance holdings and consumption. Econometrica, 52, 345-362.

Duncan, G. \& Magnuson, K. (2011). The Nature and Impact of Early Achievement Skills, Attention Skills, and Behavior Problems. In Whither Opportunity: Rising Inequality, Schools, and Children's Life Chances, ed. Greg J. Duncan and Richard J. Murnane, 47-69. New York: Russell Sage Foundation

Fang, H. \& Keane, M. (2004). Assessing the impact of welfare reform on single mothers. Brookings Papers on Economic Activity, 1, 1-116.

Fortin, P., Godbout, L., \& St-Cerny, S. (2012). Impact of Quebec's universal low fee childcare program on female labour force participation, domestic income, and government budgets. Working Paper No. 2012-02. Université de Sherbrooke.

Gelbach, J. (2002). Public schooling for young children and maternal labor supply. American Economic Review, 92, 307-322.

Hall, R. (1988). The relation between price and marginal cost in U.S. industry. Journal of Political Economy, 96, 921-947.

Herbst, C.M. (2008). Do social policy reforms have different impacts on employment and welfare use as economic conditions change? Journal of Policy Analysis and Management, 27, 867-894.

Herbst, C.M. (2010). The labor supply effects of child care costs and wages in the presence of subsidies and the Earned Income Tax Credit. Review of Economics of the Household, 8, 199-230.

Herzenberg, S., Price, M., \& Bradley, D. (2005). Losing ground in early childhood education: Declining workforce qualifications in an expanding industry, 1979-2004. Washington, DC: Economic Policy Institute.

Hotz, V. J. \& Kilburn, R. (1994). Regulating child care: The effects of state regulations on child care demand and its costs. Rand Corporation Working Paper. Santa Monica, CA: Rand Corporation.

Hotz, V. J. \& Xiao, M. (2011). The impact of regulations on the supply and quality of care in child care markets. American Economic Review, 101, 1775-1805.

Kalil, A., Ryan, R., Corey, M. (2012). Diverging destinies: Maternal education and the developmental gradient in time with children. Demography, 49, 1361-1383. 
Kaushal, N., Magnuson, K., \& Waldfogel, J. (2011). How is family income related to investments in children's learning? In Whither Opportunity: Rising Inequality, Schools, and Children's Life Chances, ed. Greg J. Duncan and Richard J. Murnane, 91-116. New York: Russell Sage Foundation.

King, M., Ruggles, S., Alexander, T., Flood, S., Genadek, K., Schroeder, M., Trampe, B., \& Vick, R. Integrated Public Use Microdata Series, Current Population Survey: Version 3.0 . [Machine-readable database]. Minneapolis: University of Minnesota, 2010.

Kornrich, S. \& Furstenberg, F. (2013). Investing in children: Changes in parental spending on children, 1972-2007. Demography, 50, 1-23.

Laughlin, L. (2013). Who's minding the kids? Child care arrangements: Spring 2011. Current Population Reports, P70-135. Washington, DC: U.S. Census Bureau.

Magnuson, K., Meyers, M., \& Waldfogel, J. (2007). The effects of expanded public funding for early education and child care on preschool enrollments during the 1990s. Social Service Review, 81, 4783.

Mocan, N. (1997). Cost functions, efficiency, and quality in day care centers. Journal of Human Resources, 32, 861-891.

Ramey, G. \& Ramey, V. (2010). The rug rat race. Brookings Papers on Economic Activity, Spring, 129-199.

Reardon, S. (2011). The Widening Academic-Achievement Gap between the Rich and the Poor: New Evidence and Possible Explanations. In Whither Opportunity: Rising Inequality, Schools, and Children's Life Chances, ed. Greg J. Duncan and Richard J. Murnane, 91-116. New York: Russell Sage Foundation.

Rosenbaum, D. \& Ruhm, C. (2007). Family expenditures on child care. The B.E. Journal of Economic Analysis and Policy: Topics, 7, 1-32.

Sandberg, J. \& Hofferth, S. (2005). Changes in children's time with parents: A correction. Demography, 42, 391-395.

Tekin, E. (2005). Child care subsidy receipt, employment, and child care choices of single mothers. Economics Letters, 89, 1-6.

U.S. Department of Health and Human Services (U.S. DHHS) (2015). Estimates of child care eligibility and receipt for fiscal year 2011. ASPE Issue Brief. Washington, DC: Office of the Assistant Secretary for Planning and Evaluation, U.S. Department of Health and Human Services. 


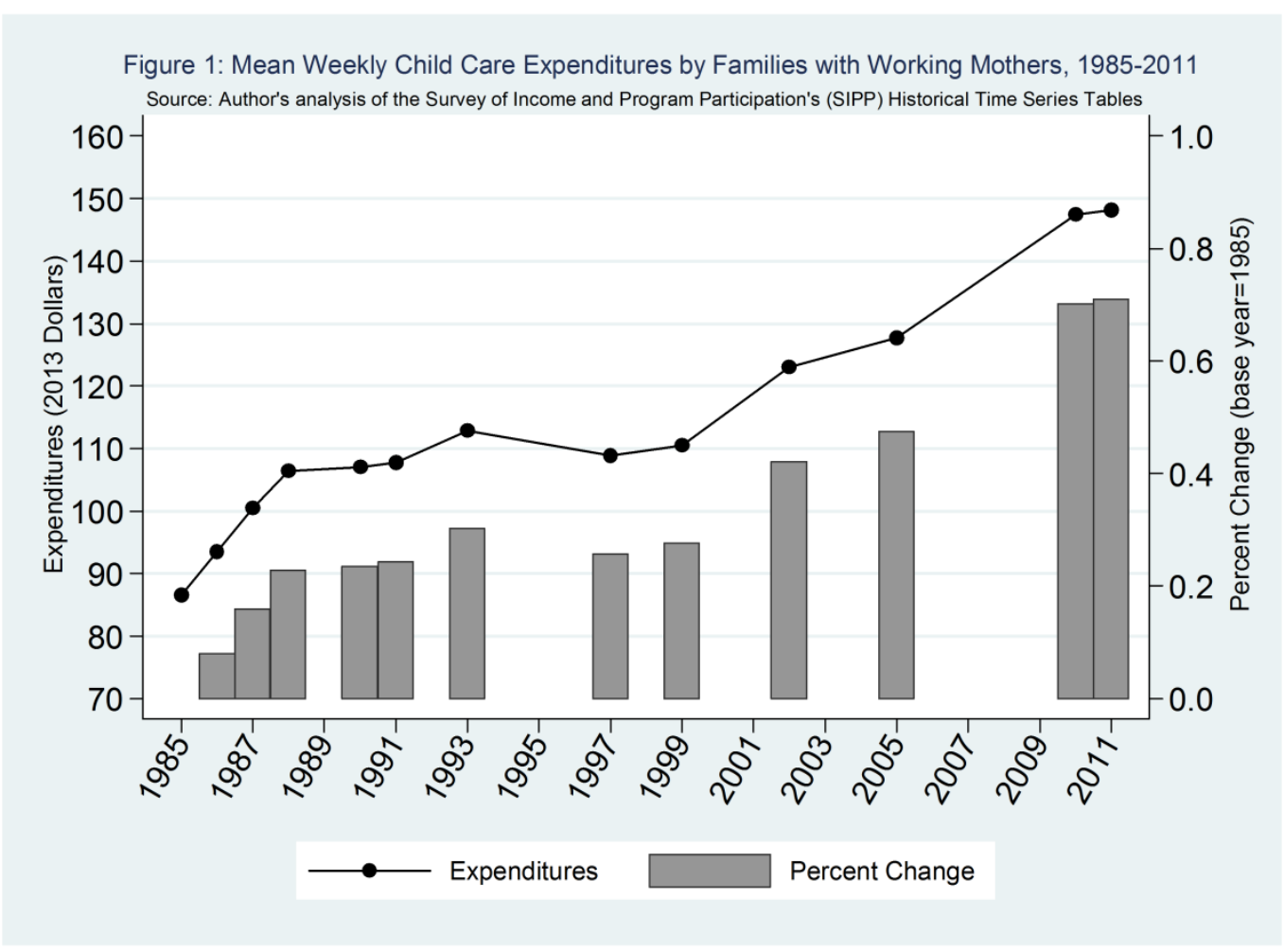

Figure 2: Annual Earnings of Private- and Public-Sector Child Care Industry Employees, 1990-2013 Source: Quarterly Census of Employment and Wages

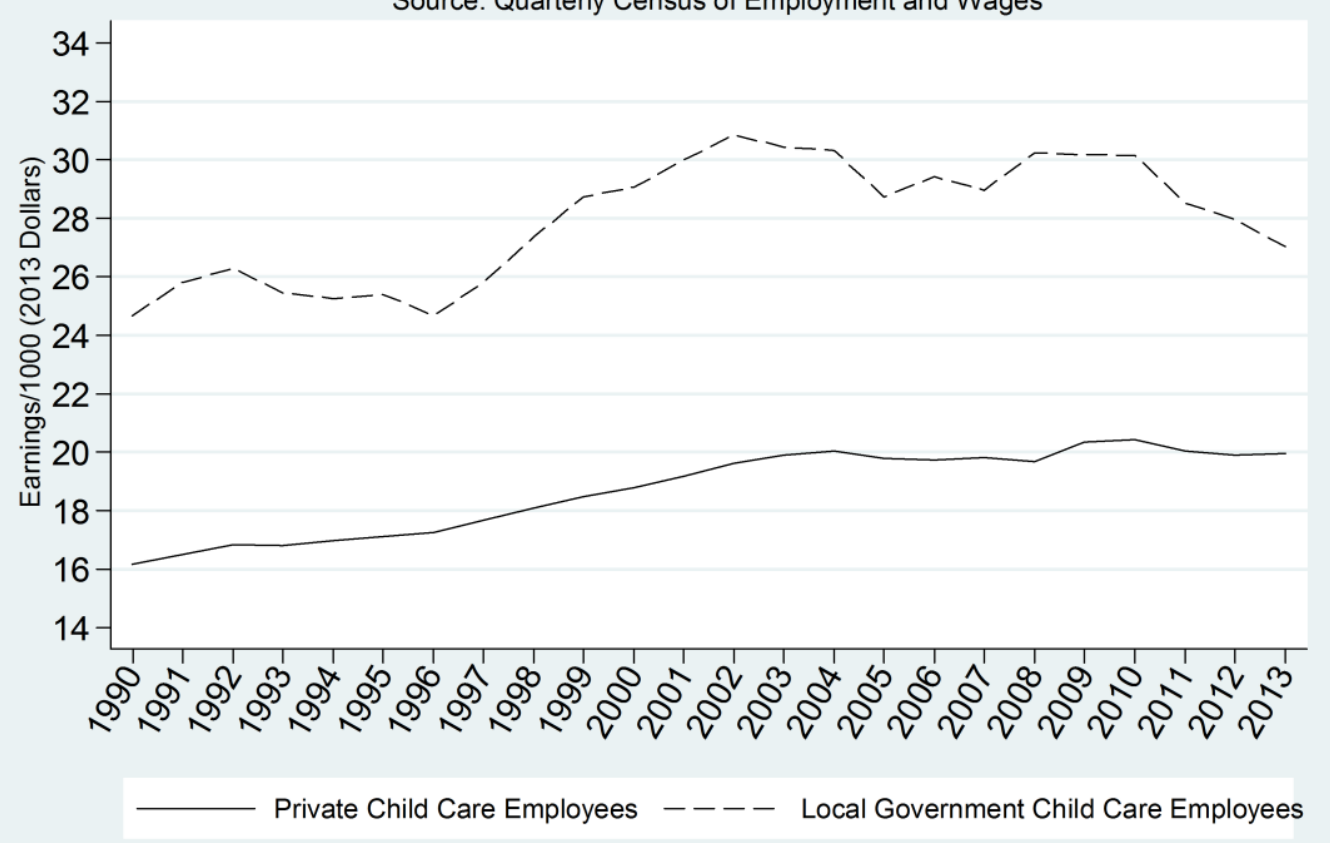


Figure 3: Annual Earnings of Private-Sector Child Care Employees, by State, 1990-2013 Source: Quarterly Census of Employment and Wages

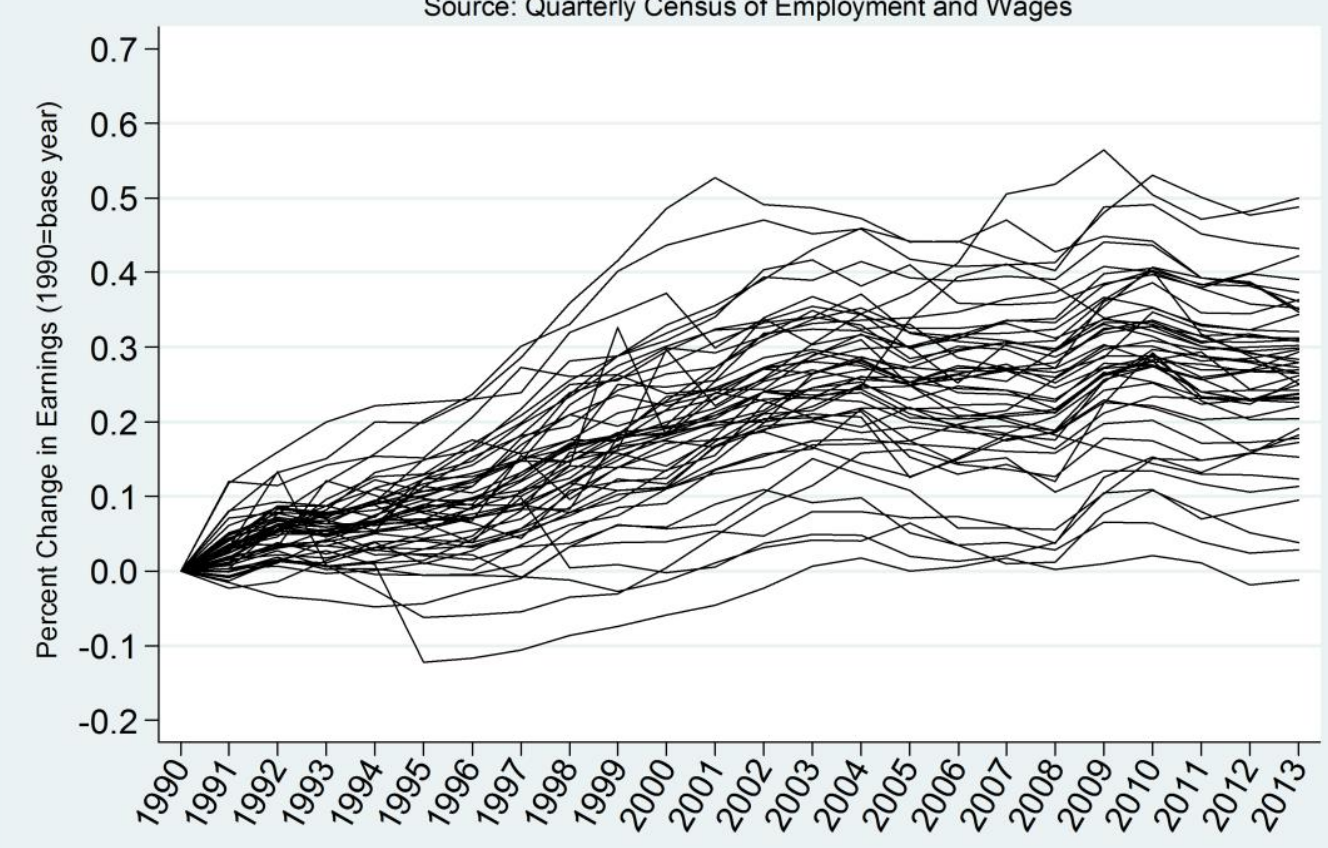

Figure 4: Annual Earnings of Private-Sector Child Care Employees, by State, 1990-2004 and 2004-2013

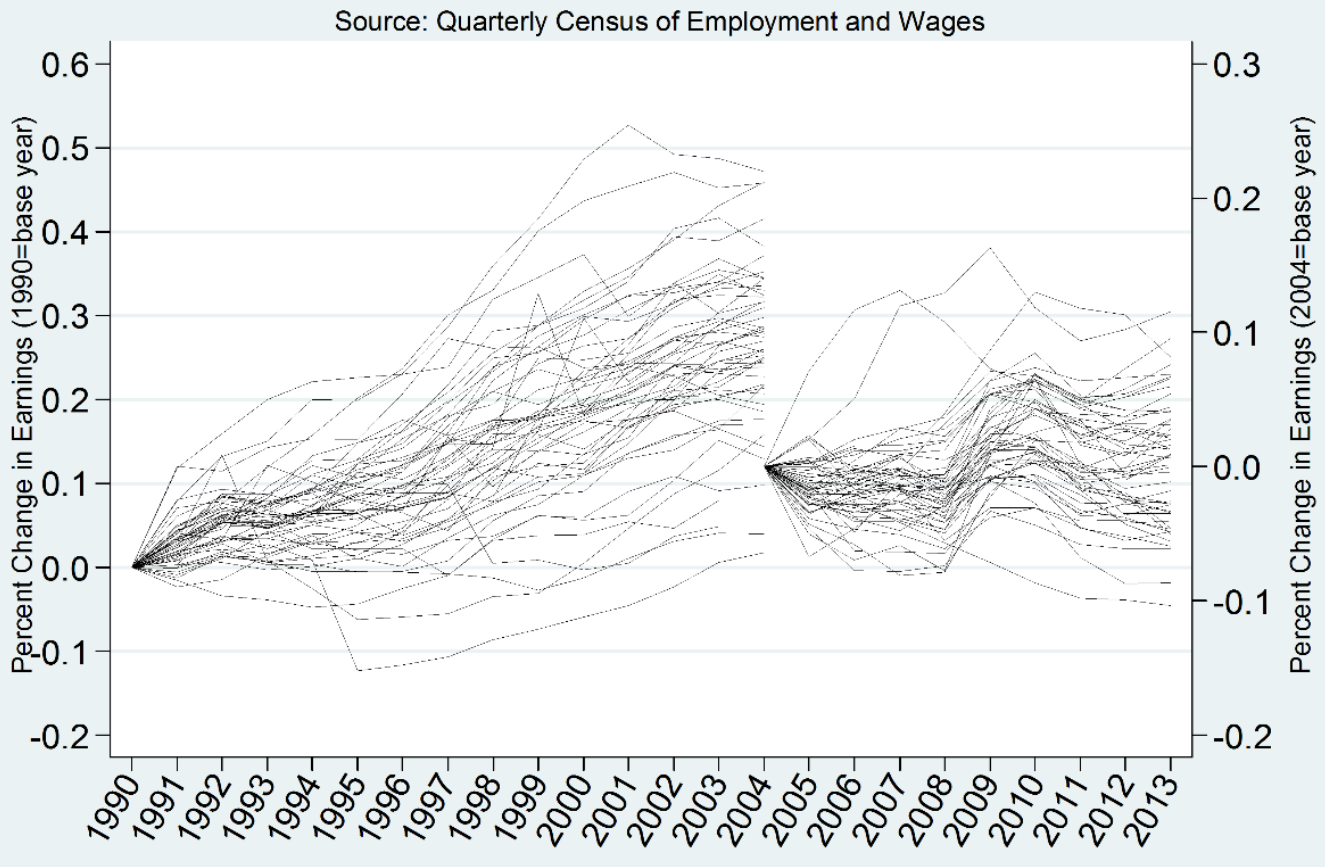


Figure 5: Annual Earnings of Public and Private Elementary/Secondary School Employees, 1990-2013 Source: Quarterly Census of Employment and Wages

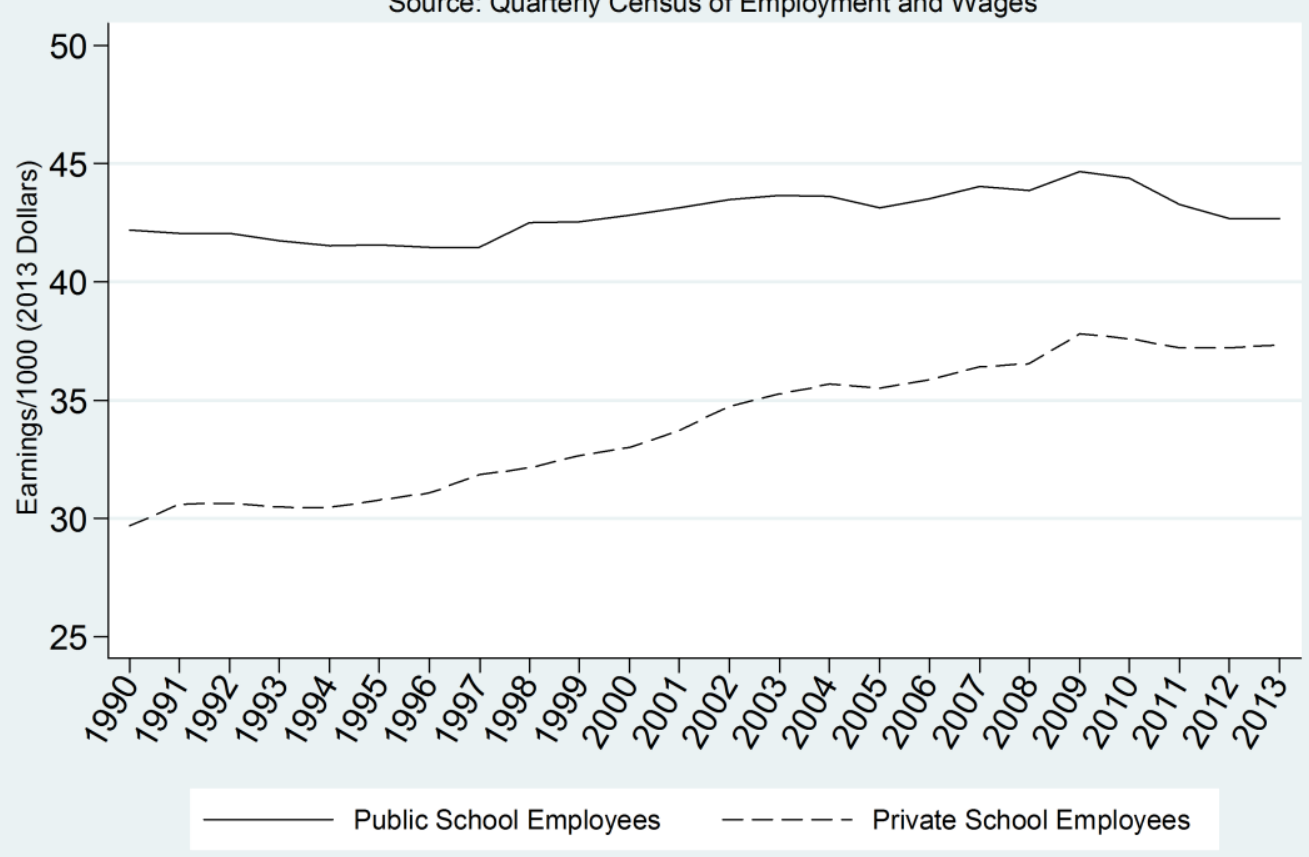

Figure 6: Annual Earnings of Private Household Employees, 1990-2013 Source: Quarterly Census of Employment and Wages

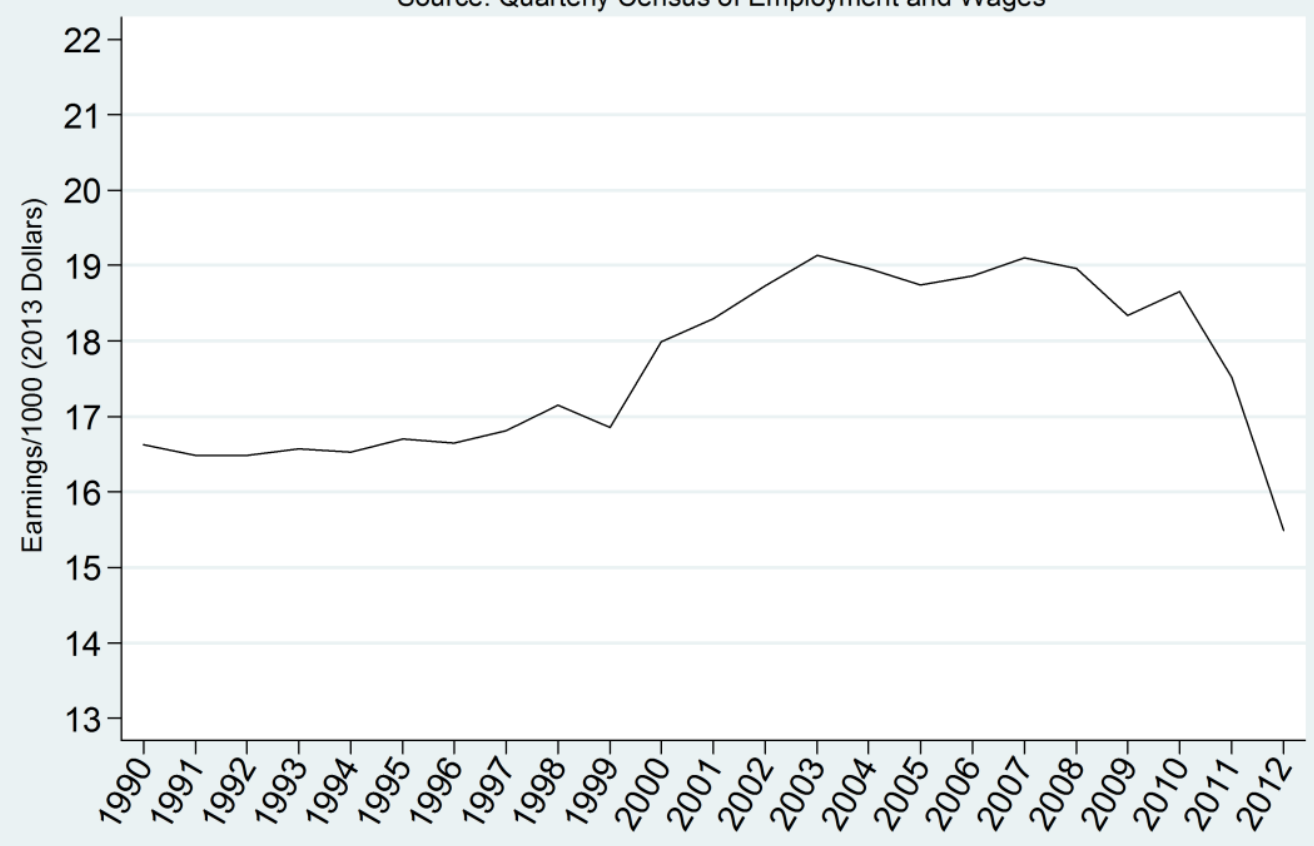



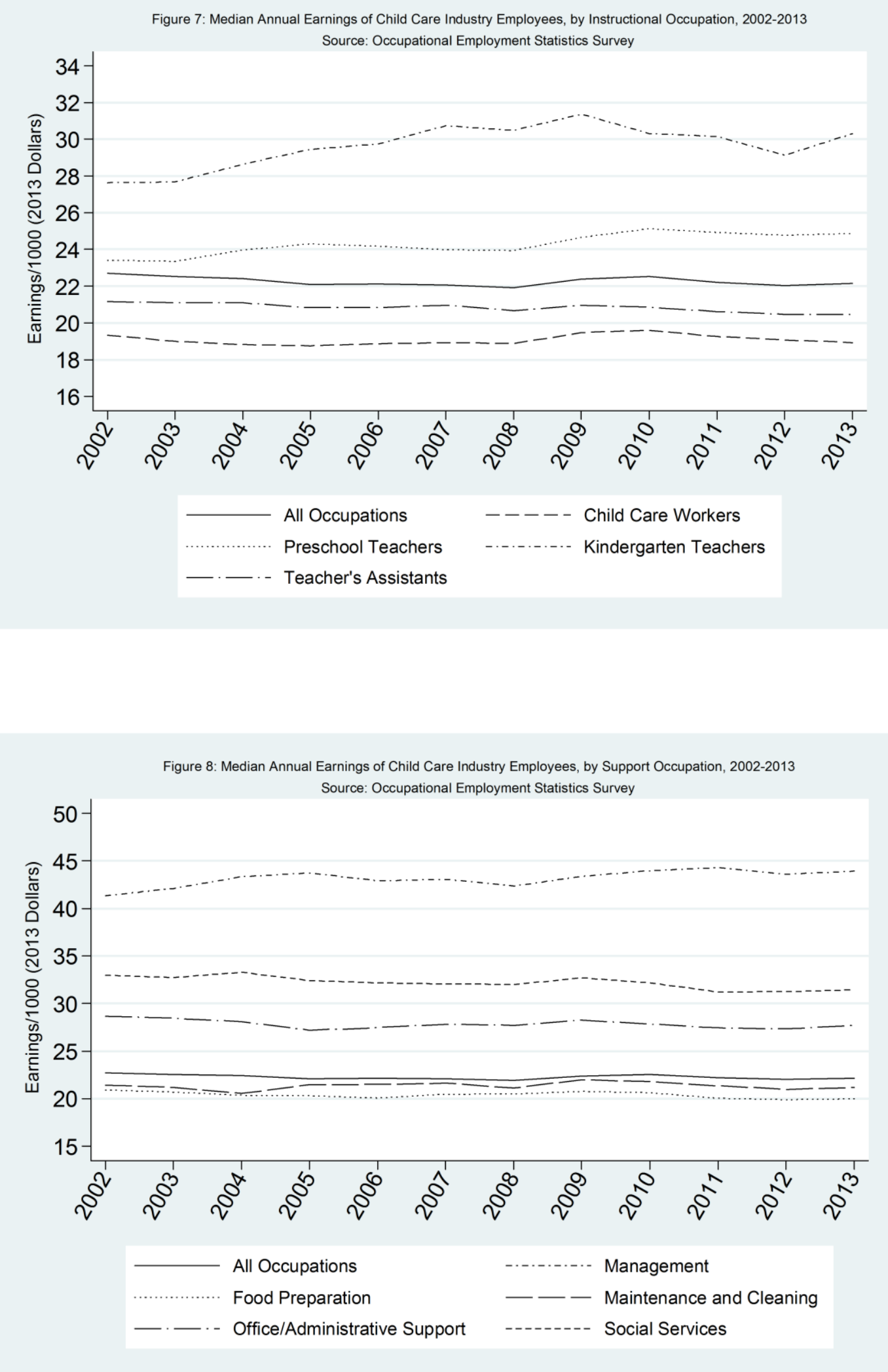
Figure 9: Median Annual Earnings of Child Care Employees, by Industry, 2002-2013 Source: Occupational Employment Statistics Survey

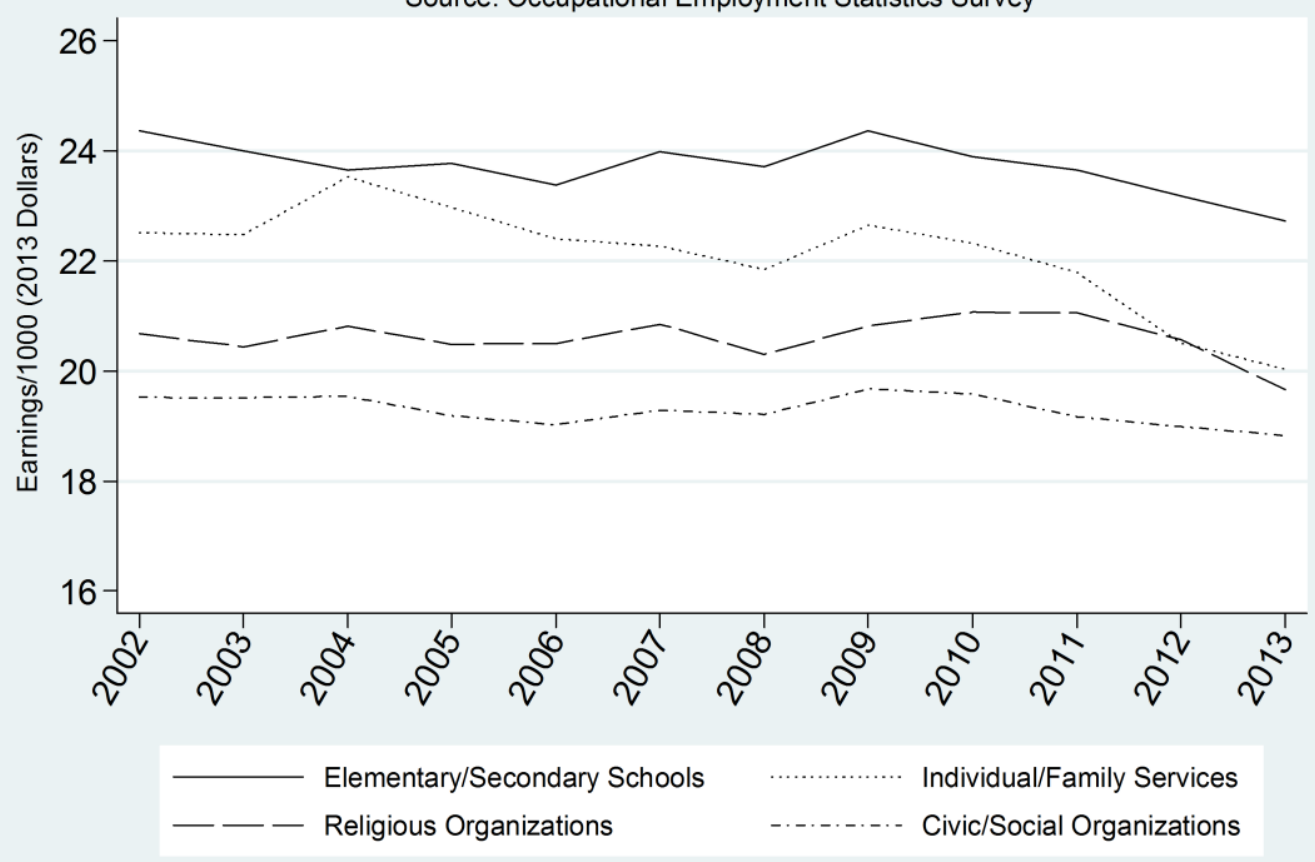

Figure 10: Median Annual Earnings of Female Workers, 1984-2013

Source: Author's analysis of the March Current Population Survey, 1985-2014

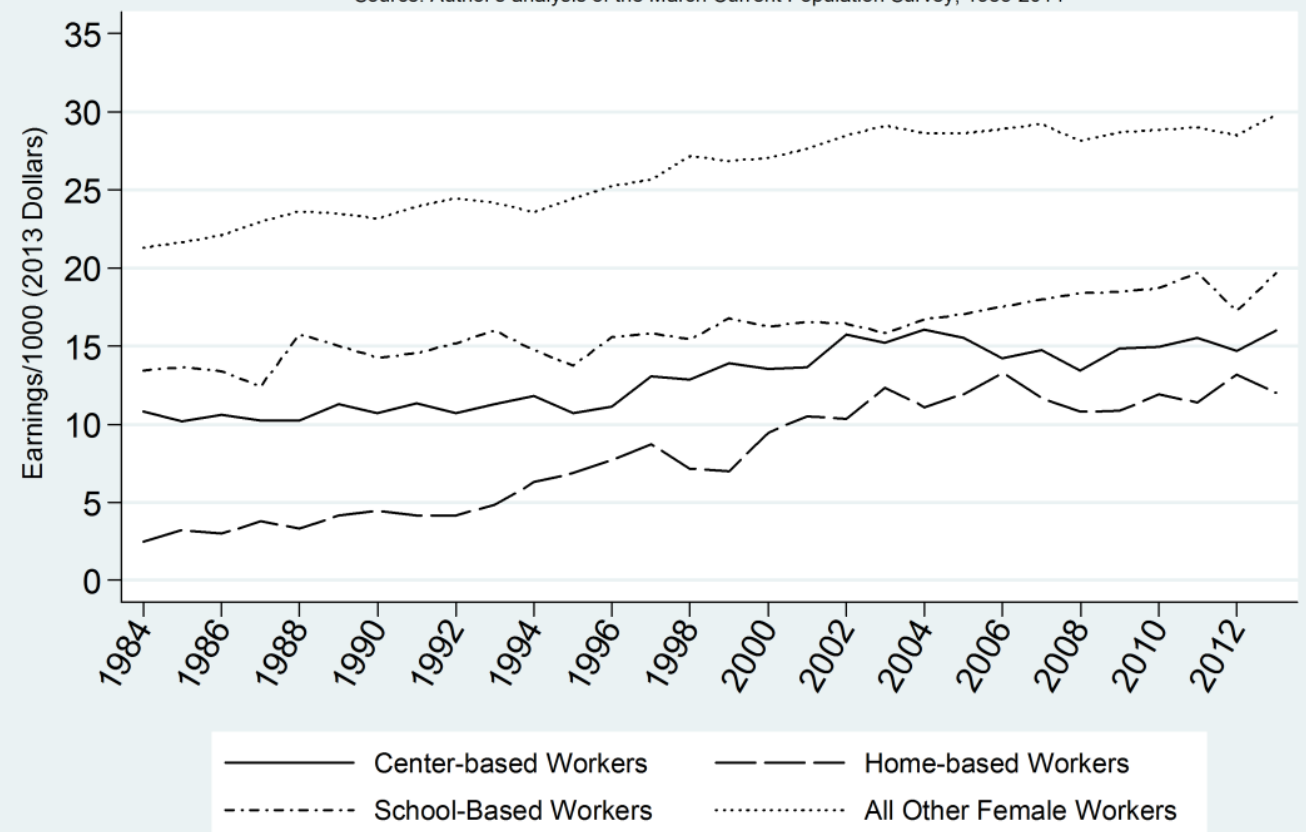




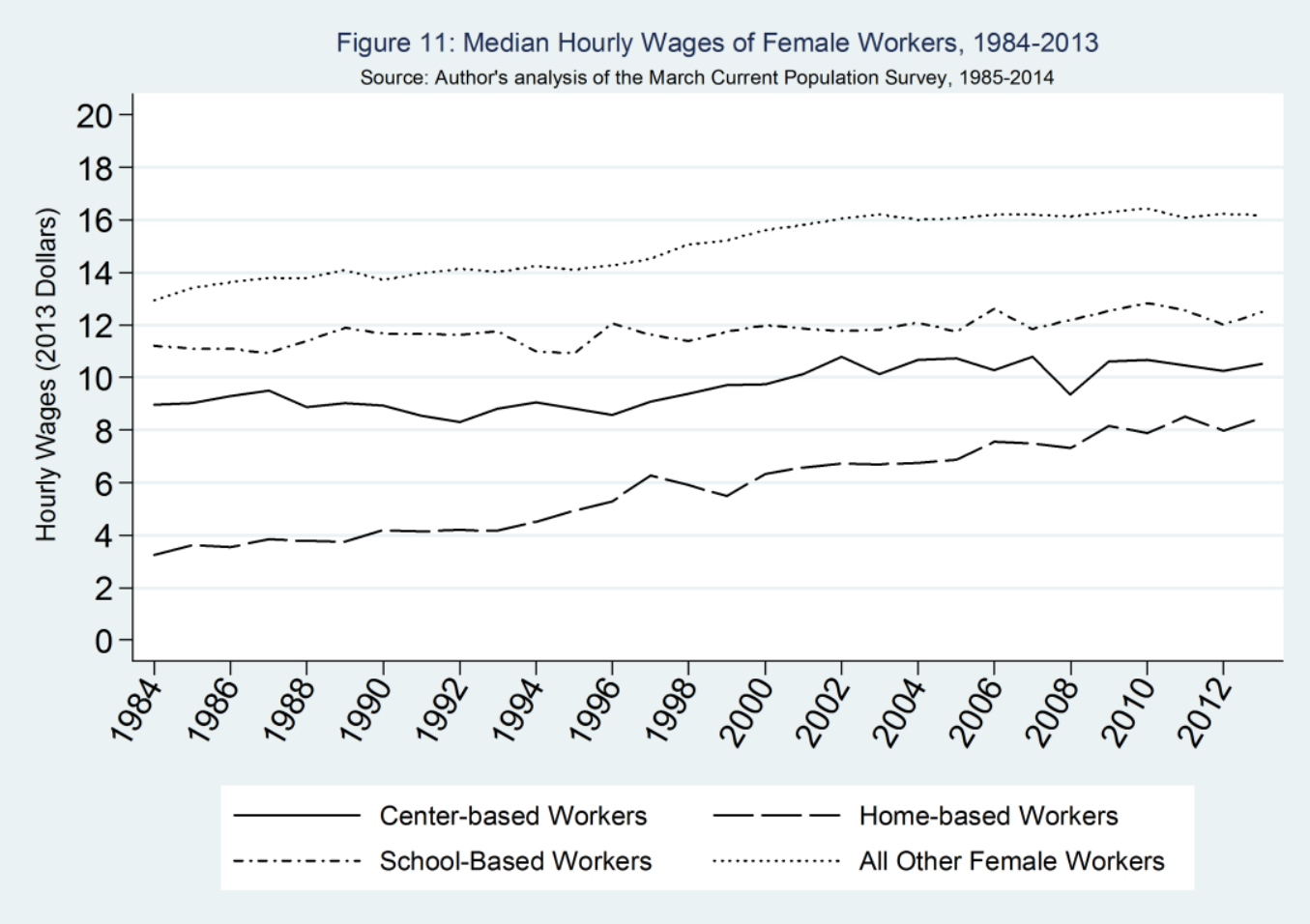

Figure 12: Labor Force Participation Rate for Women with Children Ages 0-12, 1985-2014 Source: Author's analysis of the March Current Population Survey

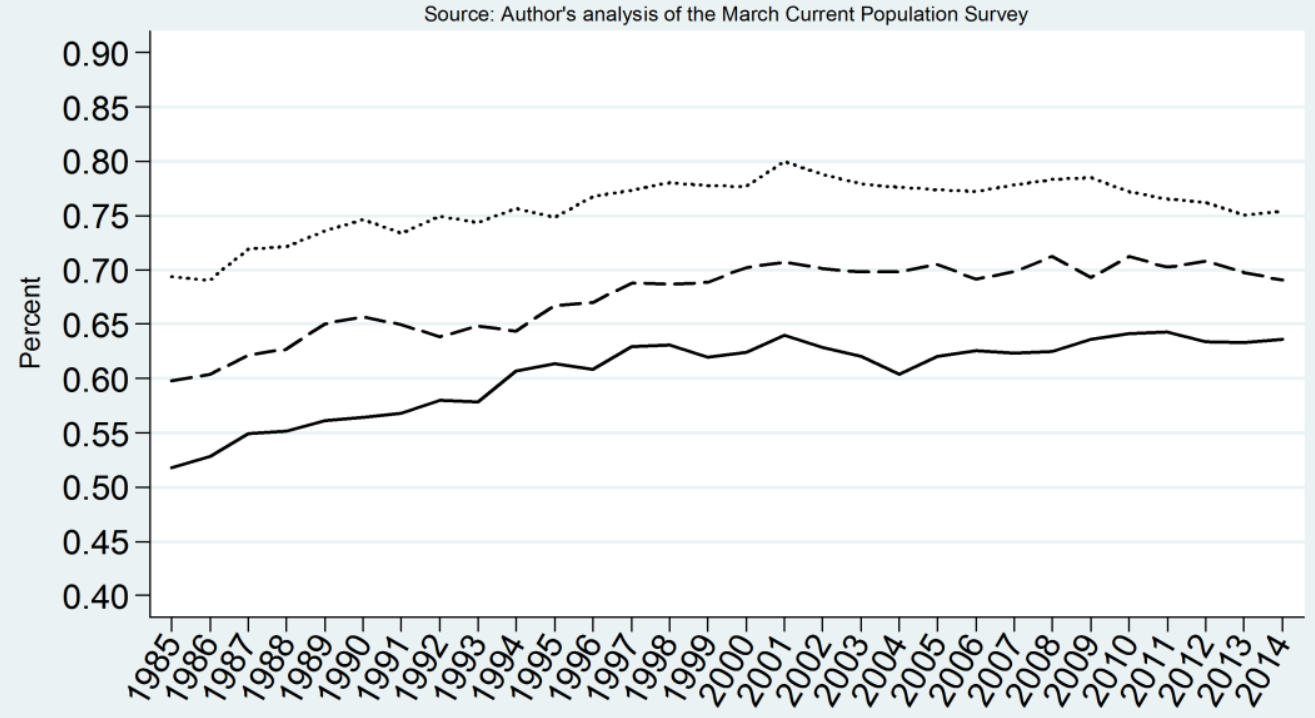

Youngest Child Ages 0-2 -

Youngest Child Ages 6-12 
Figure 13: Labor Force Participation Rate for Women with Children Ages 0-5, by Marital Status, 1985-2014

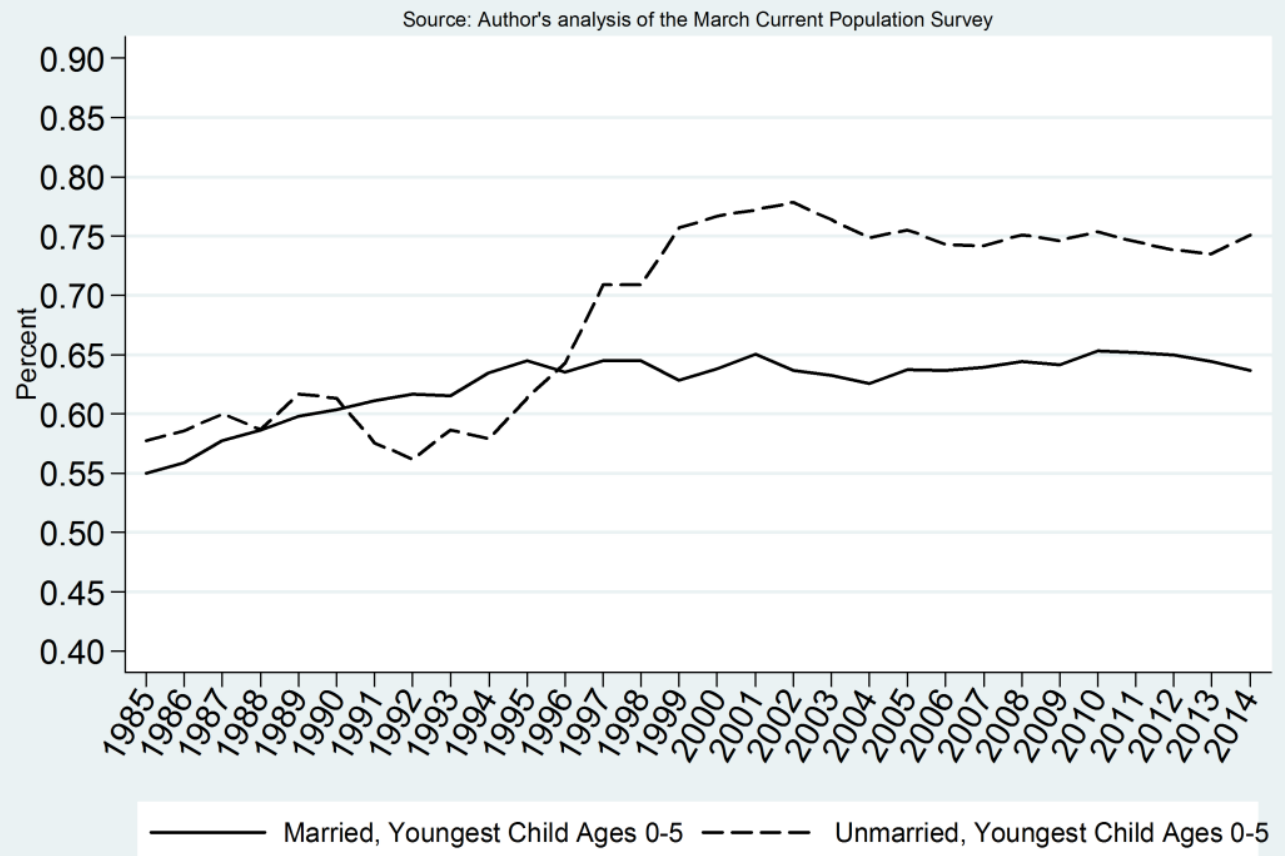

Figure 14: Participation in Formal Child Care, Children Ages 3 and 4, 1989-2010 Source: Author's analysis of the October Current Population Survey

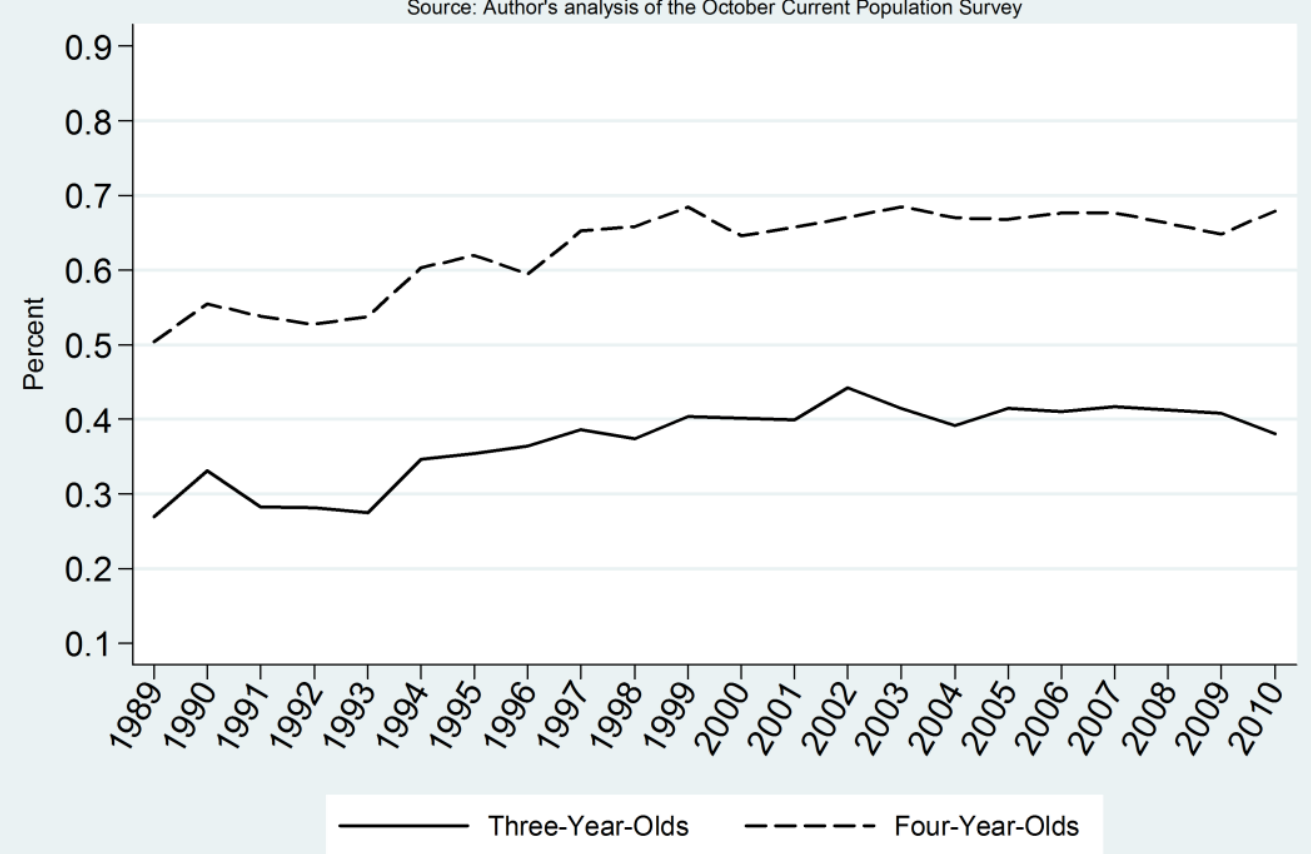


Figure 15: Educational Attainment of Center-Based Child Care Workers, 1992-2014 Source: Author's analysis of the March Current Population Survey

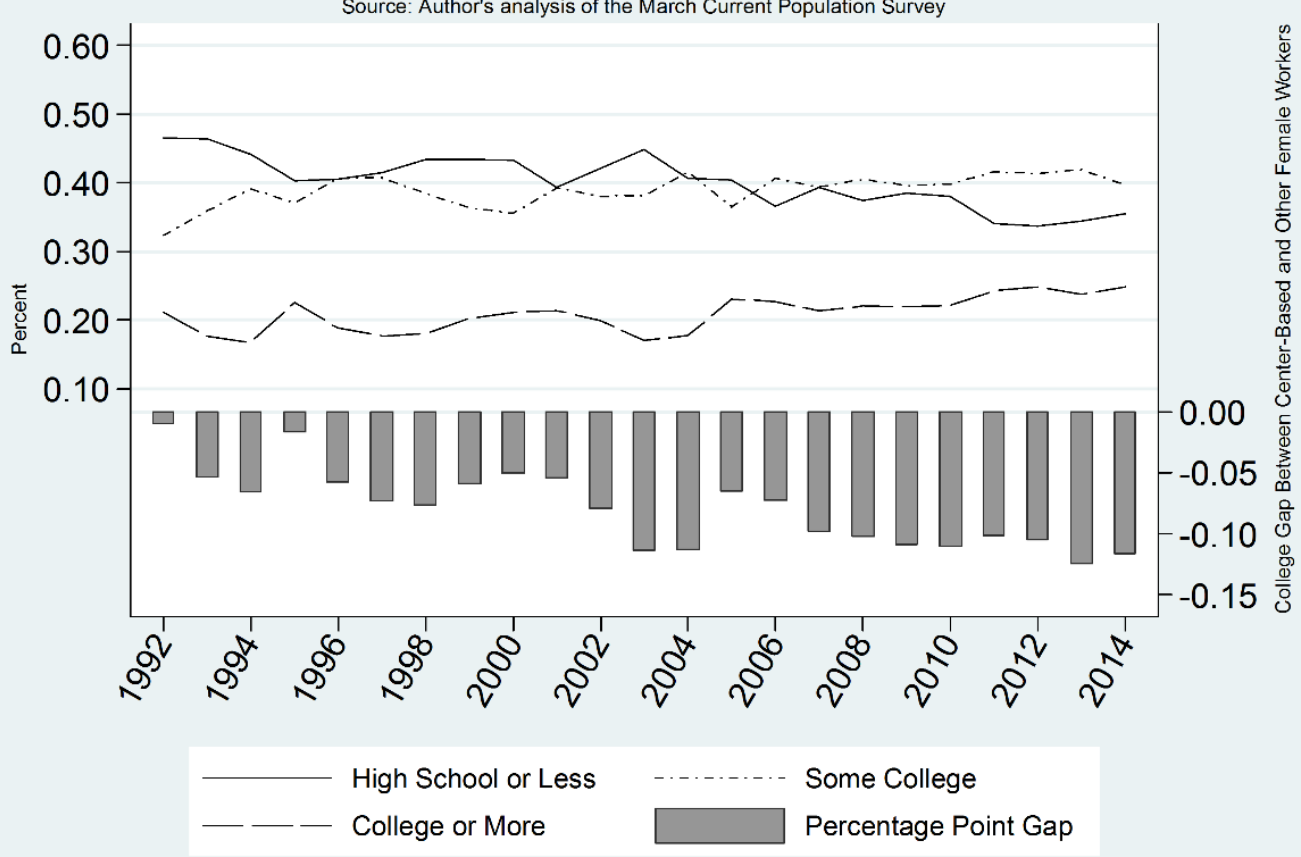

Figure 16: Educational Attainment of Home-Based Child Care Workers, 1992-2014 Source: Author's analysis of the March Current Population Survey

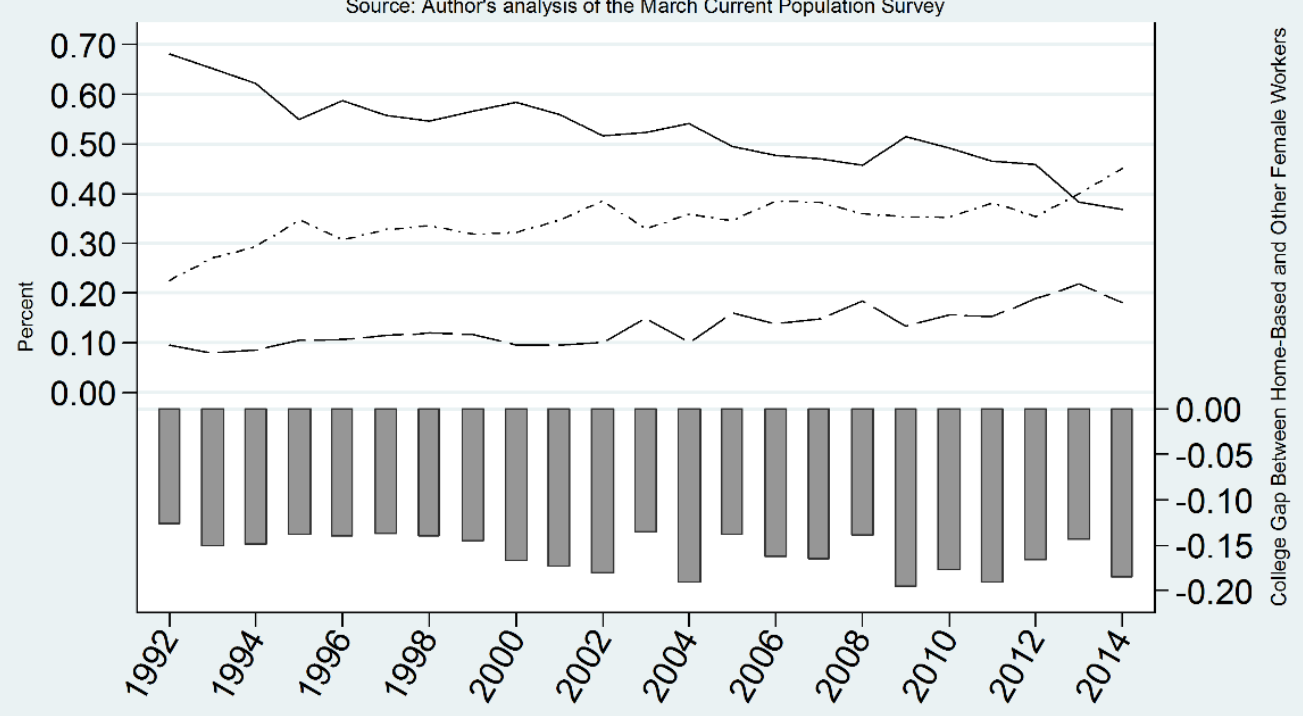

High School or Less 
Figure 17: Educational Attainment of School-Based Child Care Workers, 1992-2014

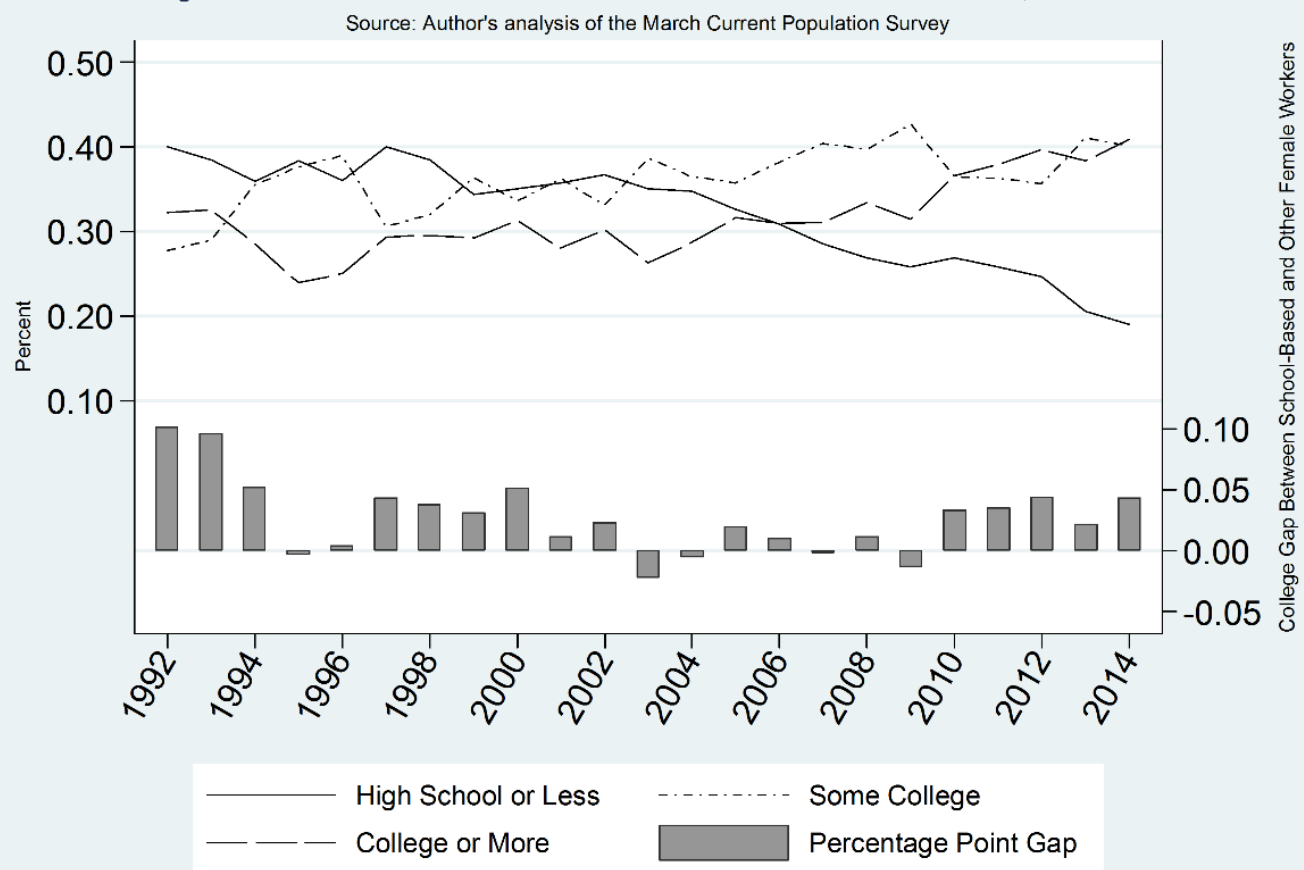


Table 1: Child Care Expenditures, 1990 and 2011

\begin{tabular}{|c|c|c|c|c|c|}
\hline & \multicolumn{2}{|c|}{$\begin{array}{l}1990 \text { SIPP, Wave } 3 \\
\text { Fall 1990 }\end{array}$} & \multicolumn{2}{|c|}{$\begin{array}{c}\text { 2008 SIPP, Wave } 8 \\
\text { Winter/Spring } 2011\end{array}$} & \multirow[b]{2}{*}{$\begin{array}{l}\text { Percent Change } \\
\text { in Expenditures }\end{array}$} \\
\hline & $\begin{array}{l}\text { Percent } \\
\text { Paying }\end{array}$ & $\begin{array}{c}\text { Weekly } \\
\text { Expenditures }\end{array}$ & $\begin{array}{l}\text { Percent } \\
\text { Paying }\end{array}$ & $\begin{array}{c}\text { Weekly } \\
\text { Expenditures }\end{array}$ & \\
\hline $\begin{array}{l}\text { Recreation of Census Bureau figures } \\
\text { (mean of expenditures) }\end{array}$ & $\begin{array}{c}0.367 \\
(0.482)\end{array}$ & $\begin{array}{l}101.14 \\
(66.50)\end{array}$ & $\begin{array}{c}0.307 \\
(0.461)\end{array}$ & $\begin{array}{c}134.44 \\
(142.49)\end{array}$ & $32.9 \%$ \\
\hline $\begin{array}{l}\text { Adjusted Census Bureau figures } \\
\text { (mean of expenditures) }\end{array}$ & $\begin{array}{c}0.367 \\
(0.482)\end{array}$ & $\begin{array}{l}101.14 \\
(66.50)\end{array}$ & $\begin{array}{c}0.269 \\
(0.443)\end{array}$ & $\begin{array}{c}139.34 \\
(143.08)\end{array}$ & $37.8 \%$ \\
\hline $\begin{array}{l}\text { Adjusted Census Bureau figures } \\
\text { (median of expenditures) }\end{array}$ & -- & 89.12 & -- & 103.56 & $16.2 \%$ \\
\hline $\begin{array}{l}\text { Expenditures per hour of work } \\
\text { (mean of expenditures) }\end{array}$ & -- & $\begin{array}{c}3.26 \\
(4.34)\end{array}$ & -- & $\begin{array}{c}4.19 \\
(6.33)\end{array}$ & $28.5 \%$ \\
\hline $\begin{array}{l}\text { Expenditures per hour of work } \\
\text { (median of expenditures) }\end{array}$ & -- & 2.27 & -- & 2.59 & $14.1 \%$ \\
\hline
\end{tabular}


Table 2: Child Care Expenditures, by Age of Youngest Child, 1990 and 2011

\begin{tabular}{|c|c|c|c|c|c|}
\hline & 1990 & $\begin{array}{l}\text { Wave } 3 \\
90\end{array}$ & $\begin{array}{l}\mathbf{2 0 0} \\
\text { Win }\end{array}$ & $\begin{array}{l}\text { Wave } 8 \\
\text { ing } 2011\end{array}$ & \\
\hline & $\begin{array}{l}\text { Percent } \\
\text { Paying }\end{array}$ & $\begin{array}{c}\text { Weekly } \\
\text { Expenditures }\end{array}$ & $\begin{array}{l}\text { Percent } \\
\text { Paying }\end{array}$ & $\begin{array}{c}\text { Weekly } \\
\text { Expenditures }\end{array}$ & $\begin{array}{l}\text { Percent Change } \\
\text { in Expenditures }\end{array}$ \\
\hline $\begin{array}{l}\text { Panel A: Youngest Child is Ages } \mathbf{0 - 5} \\
\text { Adjusted Census Bureau figures } \\
\text { (mean of expenditures) }\end{array}$ & $\begin{array}{c}0.589 \\
(0.492)\end{array}$ & $\begin{array}{l}110.26 \\
(67.69)\end{array}$ & $\begin{array}{c}0.405 \\
(0.491)\end{array}$ & $\begin{array}{c}167.38 \\
(153.48)\end{array}$ & $51.8 \%$ \\
\hline $\begin{array}{l}\text { Adjusted Census Bureau figures } \\
\text { (median of expenditures) }\end{array}$ & -- & 89.12 & -- & 124.28 & $39.5 \%$ \\
\hline $\begin{array}{l}\text { Expenditures per hour of work } \\
\text { (mean of expenditures) }\end{array}$ & -- & $\begin{array}{c}3.59 \\
(4.65)\end{array}$ & -- & $\begin{array}{c}5.12 \\
(7.10)\end{array}$ & $42.6 \%$ \\
\hline $\begin{array}{l}\text { Expenditures per hour of work } \\
\text { (median of expenditures) }\end{array}$ & -- & 2.67 & -- & 3.45 & $29.2 \%$ \\
\hline $\begin{array}{l}\text { Panel B: Youngest Child is Ages 6-14 } \\
\text { Adjusted Census Bureau figures } \\
\text { (mean of expenditures) }\end{array}$ & $\begin{array}{c}0.150 \\
(0.357)\end{array}$ & $\begin{array}{c}66.04 \\
(47.55)\end{array}$ & $\begin{array}{c}0.145 \\
(0.352)\end{array}$ & $\begin{array}{c}68.14 \\
(74.78)\end{array}$ & $3.2 \%$ \\
\hline $\begin{array}{l}\text { Adjusted Census Bureau figures } \\
\text { (median of expenditures) }\end{array}$ & -- & 53.47 & -- & 51.78 & $-3.2 \%$ \\
\hline $\begin{array}{l}\text { Expenditures per hour of work } \\
\text { (mean of expenditures) }\end{array}$ & -- & $\begin{array}{c}1.94 \\
(2.38)\end{array}$ & -- & $\begin{array}{l}1.81 \\
(2.46)\end{array}$ & $-6.7 \%$ \\
\hline $\begin{array}{l}\text { Expenditures per hour of work } \\
\text { (median of expenditures) }\end{array}$ & -- & 1.34 & -- & 1.24 & $-7.5 \%$ \\
\hline
\end{tabular}


Table 3: Child Care Expenditures, by Demographic Sub-Group, 1990 and 2011

\begin{tabular}{|c|c|c|c|c|c|c|c|}
\hline & \multicolumn{3}{|c|}{$\begin{array}{l}1990 \text { SIPP, Wave } 3 \\
\text { Fall } 1990\end{array}$} & \multicolumn{3}{|c|}{$\begin{array}{l}2008 \text { SIPP, Wave } 8 \\
\text { Winter/Spring } 2011\end{array}$} & \multirow[b]{2}{*}{$\begin{array}{l}\text { Percent Change } \\
\text { in Expenditures }\end{array}$} \\
\hline & $\begin{array}{l}\text { Percent } \\
\text { Paying }\end{array}$ & $\begin{array}{c}\text { Weekly } \\
\text { Expenditures } \\
\end{array}$ & $\begin{array}{l}\text { Per Hour } \\
\text { of Work }\end{array}$ & $\begin{array}{l}\text { Percent } \\
\text { Paying }\end{array}$ & $\begin{array}{c}\text { Weekly } \\
\text { Expenditures }\end{array}$ & $\begin{array}{l}\text { Per Hour } \\
\text { of Work }\end{array}$ & \\
\hline \multicolumn{8}{|c|}{ Panel A: Youngest Child is Ages 0-5 } \\
\hline Unmarried & 0.594 & 89.12 & 2.41 & 0.366 & 99.42 & 2.67 & $11.6 \% \mid 10.8 \%$ \\
\hline Married & 0.588 & 92.68 & 2.70 & 0.426 & 144.99 & 3.88 & $56.4 \% \mid 43.7 \%$ \\
\hline High school or less & 0.554 & 89.12 & 2.29 & 0.283 & 93.21 & 2.49 & $4.6 \% \mid 8.7 \%$ \\
\hline More than high school & 0.631 & 106.94 & 2.99 & 0.455 & 134.63 & 3.73 & $25.9 \% \mid 24.8 \%$ \\
\hline Bottom income quartile & 0.507 & 80.21 & 2.23 & 0.273 & 82.85 & 2.46 & $3.3 \% \mid 10.3 \%$ \\
\hline Middle income quartiles & 0.589 & 89.12 & 2.45 & 0.410 & 103.56 & 2.90 & $16.2 \% \mid 18.4 \%$ \\
\hline Top income quartile & 0.683 & 124.77 & 3.34 & 0.537 & 186.42 & 4.93 & $49.4 \% \mid 47.6 \%$ \\
\hline \multicolumn{8}{|c|}{ Panel B: Youngest Child is Ages 6-14 } \\
\hline Unmarried & 0.213 & 62.38 & 1.34 & 0.154 & 51.78 & 1.24 & $-16.8 \% \mid-7.5 \%$ \\
\hline Married & 0.121 & 46.34 & 1.25 & 0.140 & 47.64 & 1.21 & $2.8 \% \mid-3.2 \%$ \\
\hline High school or less & 0.140 & 44.56 & 1.11 & 0.105 & 51.78 & 1.17 & $16.2 \% \mid 5.4 \%$ \\
\hline More than high school & 0.162 & 62.38 & 1.53 & 0.161 & 51.78 & 1.24 & $-17.0 \% \mid-19.0 \%$ \\
\hline Bottom income quartile & 0.137 & 49.91 & 1.11 & 0.094 & 51.78 & 1.04 & $3.8 \% \mid-6.3 \%$ \\
\hline Middle income quartiles & 0.141 & 49.91 & 1.27 & 0.144 & 51.78 & 1.29 & $3.8 \% \mid 1.6 \%$ \\
\hline Top income quartile & 0.179 & 62.38 & 1.47 & 0.195 & 51.78 & 1.04 & $-17.0 \% \mid-29.3 \%$ \\
\hline
\end{tabular}

Source: Author's analysis of the 1990 (Wave 3) and 2008 (Wave 8) SIPP

Notes: All expenditure figures are expressed in constant 2013 dollars. The number to the left of "|" in the "percent change" column refers to weekly

expenditures; the number to the right refers to hourly expenditures. Estimates are weighted using the final SIPP person weight. 
Table 4: Distribution of Primary Child Care Arrangements, by Age of Child, 1990 and 2011

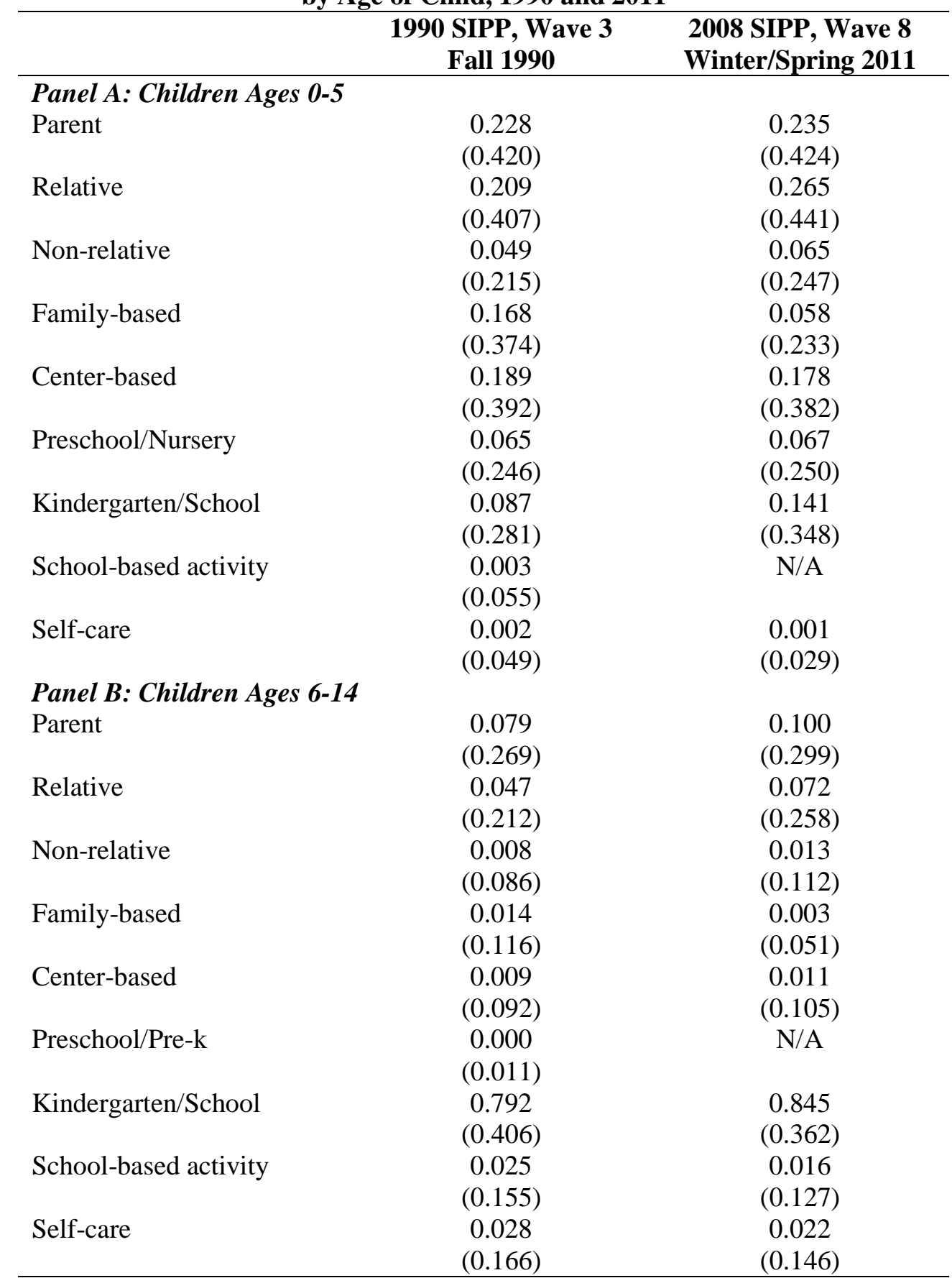

Source: Author's analysis of the 1990 (Wave 3) and 2008 (Wave 8) SIPP

Notes: Estimates are based on the full sample of children, and are weighted using the final SIPP person weight. The 1990 SIPP sample includes 2,963 observations in Panel A and 4,895 observations in Panel B. The 2008 SIPP sample includes 3,781 observations in Panel A and 6,678 observations in Panel B. Participation rates may sum to over 100 percent because some children participate in multiple, primary child care arrangements. The unit of analysis is the child. 
Table 5: Expenditures on the Primary Child Care Arrangement, Children Ages 0-5, 1990 and 2011

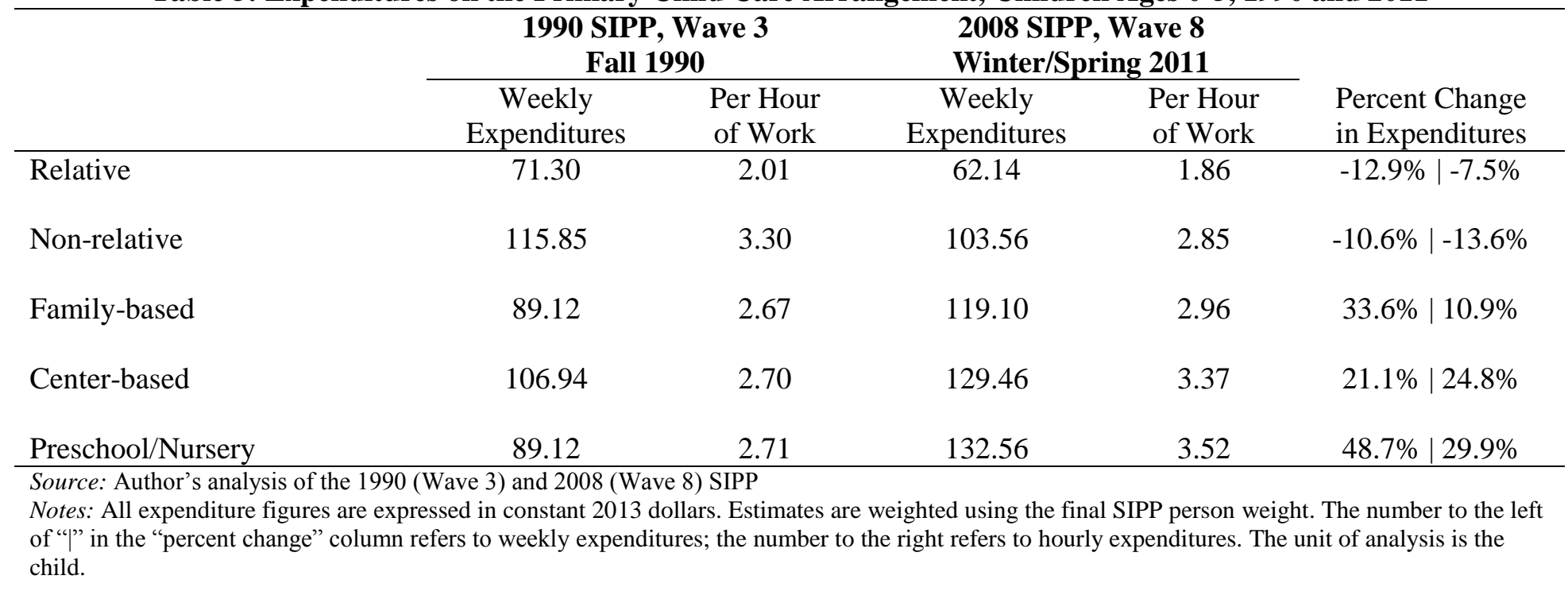


Table 6: Expenditures on the Primary Child Care Arrangement, by Demographic Sub-Group, 1990 and 2011

\begin{tabular}{|c|c|c|c|c|c|}
\hline & \multicolumn{2}{|c|}{$\begin{array}{c}1990 \text { SIPP, Wave } 3 \\
\text { Fall 1990 }\end{array}$} & \multicolumn{2}{|c|}{$\begin{array}{c}2008 \text { SIPP, Wave } 8 \\
\text { Winter/Spring } 2011\end{array}$} & \multirow[b]{2}{*}{$\begin{array}{l}\text { Percent Change } \\
\text { in Expenditures }\end{array}$} \\
\hline & $\begin{array}{c}\text { Weekly } \\
\text { Expenditures }\end{array}$ & $\begin{array}{l}\text { Per Hour } \\
\text { of Work }\end{array}$ & $\begin{array}{c}\text { Weekly } \\
\text { Expenditures }\end{array}$ & $\begin{array}{l}\text { Per Hour } \\
\text { of Work }\end{array}$ & \\
\hline \multicolumn{6}{|l|}{ Relative } \\
\hline Unmarried & 71.30 & 2.01 & 51.78 & 1.29 & \begin{tabular}{l|l}
$-27.4 \%$ & $-35.8 \%$
\end{tabular} \\
\hline Married & 71.30 & 1.90 & 77.67 & 2.07 & $8.9 \% \mid 9.0 \%$ \\
\hline High school or less & 71.30 & 1.78 & 51.78 & 1.29 & $-27.4 \% \mid-27.5 \%$ \\
\hline More than high school & 89.12 & 2.23 & 82.85 & 2.37 & $-7.0 \% \mid 6.3 \%$ \\
\hline \multicolumn{6}{|l|}{ Non-relative/Family } \\
\hline Unmarried & 89.12 & 2.23 & 82.85 & 2.59 & $-7.0 \% \mid 16.1 \%$ \\
\hline Married & 98.03 & 2.90 & 124.28 & 3.33 & $26.8 \% \mid 14.8 \%$ \\
\hline High school or less & 89.12 & 2.23 & 77.67 & 2.22 & \begin{tabular}{l|l}
$-12.9 \%$ & $-0.5 \%$
\end{tabular} \\
\hline More than high school & 106.94 & 3.12 & 119.10 & 3.24 & $11.4 \% \mid 3.9 \%$ \\
\hline \multicolumn{6}{|l|}{ Center/Preschool/Nursery } \\
\hline Unmarried & 98.03 & 2.66 & 98.39 & 2.59 & $0.4 \% \mid-2.6 \%$ \\
\hline Married & 99.81 & 2.71 & 144.99 & 3.80 & $45.3 \% \mid 40.2 \%$ \\
\hline High school or less & 92.68 & 2.53 & 77.67 & 2.07 & $-16.2 \% \mid-18.2 \%$ \\
\hline More than high school & 110.51 & 2.94 & 134.63 & 3.62 & $21.8 \% \mid 23.1 \%$ \\
\hline
\end{tabular}


Table 7: Percent of Income Spent on Child Care, by Demographic Sub-Group, 1990 and 2011

\begin{tabular}{|c|c|c|}
\hline & $\begin{array}{l}1990 \text { SIPP, Wave } 3 \\
\text { Fall 1990 }\end{array}$ & $\begin{array}{l}2008 \text { SIPP, Wave } 8 \\
\text { Winter/Spring } 2011\end{array}$ \\
\hline \multicolumn{3}{|c|}{ Panel A: Youngest Child is Ages 0-5 } \\
\hline Full sample & 0.093 & 0.107 \\
\hline Unmarried & 0.134 & 0.134 \\
\hline Married & 0.080 & 0.096 \\
\hline High school or less & 0.100 & 0.117 \\
\hline More than high school & 0.087 & 0.105 \\
\hline Bottom income quartile & 0.165 & 0.174 \\
\hline Middle income quartiles & 0.085 & 0.108 \\
\hline Top income quartile & 0.053 & 0.078 \\
\hline \multicolumn{3}{|c|}{ Panel B: Youngest Child is Ages 6-14 } \\
\hline Full sample & 0.062 & 0.050 \\
\hline Unmarried & 0.086 & 0.071 \\
\hline Married & 0.044 & 0.037 \\
\hline High school or less & 0.066 & 0.068 \\
\hline More than high school & 0.059 & 0.045 \\
\hline Bottom income quartile & 0.140 & 0.117 \\
\hline Middle income quartiles & 0.049 & 0.052 \\
\hline Top income quartile & 0.030 & 0.021 \\
\hline
\end{tabular}

Source: Author's analysis of the 1990 (Wave 3) and 2008 (Wave 8) SIPP

Notes: Estimates are weighted using the final SIPP person weight. The unit of analysis is the family.

"Full Sample" in Panel A and Panel B refers to the full set of families in which the youngest child is ages 0 to 5 and ages 6 to 14 , respectively. 
Table 8: Monthly Operating Costs of Child Care Centers in the CQCOS

\begin{tabular}{lcccc}
\hline & \multicolumn{2}{c}{ Non-Profit Centers } & \multicolumn{2}{c}{ For-Profit Centers } \\
\cline { 2 - 5 } & $\begin{array}{c}\text { Monthly } \\
\text { Cost/Child }\end{array}$ & $\begin{array}{c}\text { Percent } \\
\text { of Total }\end{array}$ & $\begin{array}{c}\text { Monthly } \\
\text { Cost/Child }\end{array}$ & $\begin{array}{c}\text { Percent } \\
\text { of Total }\end{array}$ \\
\hline Labor & 534.06 & 78.9 & 384.81 & 61.8 \\
Occupancy & 49.91 & 7.4 & 126.02 & 20.2 \\
Food & 33.37 & 4.9 & 26.49 & 4.3 \\
Overhead & 13.72 & 2.0 & 18.09 & 2.9 \\
Other operating expenses & 45.54 & 6.7 & 64.89 & 10.4 \\
Total & 677.12 & 100.0 & 622.78 & 100.0 \\
\hline Source: Adopted from Morris, Helburn, \& Culkin (1995) & & &
\end{tabular}

Notes: All cost figures are expressed in constant 2013 dollars. Column percentages may not add to 100 due to rounding. 
Table 9: Payroll Share of Revenue, by Industry, 1997-2012

\begin{tabular}{|c|c|c|c|c|}
\hline & 1997 & 2002 & 2007 & 2012 \\
\hline \multicolumn{5}{|c|}{ Panel A: Health Care and Social Assistance (NAICS: 62) } \\
\hline \multicolumn{5}{|c|}{ Child day care services (6244) } \\
\hline Payroll costs & 10,108 & 13,603 & 15,682 & 15,819 \\
\hline Revenue & 20,578 & 28,198 & 33,366 & 32,476 \\
\hline Percent & 0.491 & 0.482 & 0.470 & 0.487 \\
\hline \multicolumn{5}{|c|}{ Individual and family services (6241) } \\
\hline Payroll costs & 17,267 & 22,950 & 28,048 & 31,654 \\
\hline Revenue & 42,229 & 57,824 & 70,880 & 75,818 \\
\hline Percent & 0.409 & 0.397 & 0.396 & 0.417 \\
\hline \multicolumn{5}{|c|}{ Vocational rehabilitation services (6243) } \\
\hline Payroll costs & 5,472 & 6,317 & 5,805 & 5,769 \\
\hline Revenue & 11,460 & 14,287 & 12,966 & 12,669 \\
\hline Percent & 0.477 & 0.442 & 0.448 & 0.455 \\
\hline \multicolumn{5}{|c|}{ Nursing and residential care facilities (623) } \\
\hline Payroll costs & 61,193 & 76,381 & 83,815 & 87,832 \\
\hline Revenue & 135,125 & 164,633 & 190,019 & 206,137 \\
\hline Percent & 0.453 & 0.464 & 0.441 & 0.426 \\
\hline \multicolumn{5}{|c|}{ Panel B: Professional/Scientific/Technical Services (NAICS: 54) } \\
\hline \multicolumn{5}{|c|}{ Legal Services (5411) } \\
\hline Payroll costs & 72,378 & 90,492 & 100,135 & 94,871 \\
\hline Revenue & 186,616 & 235,847 & 269,076 & 267,029 \\
\hline Percent & 0.388 & 0.384 & 0.372 & 0.355 \\
\hline \multicolumn{5}{|c|}{ Advertising and Public Relations (5418) } \\
\hline Payroll costs & 23,245 & 25,235 & 29,368 & 28,887 \\
\hline Revenue & 71,555 & 73,411 & 98,274 & 96,635 \\
\hline Percent & 0.325 & 0.344 & 0.299 & 0.299 \\
\hline \multicolumn{5}{|c|}{ Panel C: Accommodations and Food Services (NAICS: 72) } \\
\hline \multicolumn{5}{|c|}{ Hotels and Other Accommodations (721) } \\
\hline Payroll costs & 38,723 & 45,272 & 52,145 & 50,898 \\
\hline Revenue & 142,931 & 165,908 & 202,755 & 198,339 \\
\hline Percent & 0.271 & 0.273 & 0.257 & 0.257 \\
\hline \multicolumn{5}{|c|}{ Food Services and Drinking Places (722) } \\
\hline Payroll costs & 102,105 & 119,931 & 139,861 & 148,230 \\
\hline Revenue & 365,748 & 416,267 & 487,136 & 520,611 \\
\hline Percent & 0.279 & 0.288 & 0.287 & 0.285 \\
\hline \multicolumn{5}{|c|}{ Panel D: Other Service-Based Industries (NAICS: 61 and 81) } \\
\hline \multicolumn{5}{|c|}{ Educational Services (611) } \\
\hline Payroll costs & 9,240 & 13,164 & 16,027 & 17,921 \\
\hline Revenue & 29,672 & 39,750 & 50,558 & 55,515 \\
\hline Percent & 0.311 & 0.331 & 0.317 & 0.323 \\
\hline \multicolumn{5}{|c|}{ Religious, Grantmaking, Civic, and Professional Orgs (813) } \\
\hline Payroll costs & 24,778 & 32,287 & 36,298 & 38,612 \\
\hline Revenue & 149,329 & 150,916 & 208,438 & 200,643 \\
\hline Percent & 0.166 & 0.214 & 0.174 & 0.192 \\
\hline
\end{tabular}

Source: Author's analysis of the 1997, 2002, 2007, and 2012 Economic Census

Notes: All revenue and payroll figures are expressed in constant 2013 dollars. All figures are expressed in millions of dollars. The percent calculations are made by dividing payroll costs by revenue. 
Table 11: Estimates from the Selection-Corrected Wage Equations

\begin{tabular}{|c|c|c|c|c|}
\hline Variable & $\begin{array}{l}\text { Center-Based } \\
\text { Sector }\end{array}$ & $\begin{array}{l}\text { Home-Based } \\
\text { Sector }\end{array}$ & $\begin{array}{l}\text { School-Based } \\
\text { Sector }\end{array}$ & $\begin{array}{l}\text { Non-Child Care } \\
\text { Sector }\end{array}$ \\
\hline \multicolumn{5}{|l|}{ Panel A: 1991-2001 } \\
\hline High school & $\begin{array}{l}0.292 * * * \\
(0.062)\end{array}$ & $\begin{array}{l}0.141 * * \\
(0.061)\end{array}$ & $\begin{array}{c}0.046 \\
(0.096)\end{array}$ & $\begin{array}{l}0.327 * * * \\
(0.008)\end{array}$ \\
\hline Some college & $\begin{array}{l}0.482 * * * \\
(0.079)\end{array}$ & $\begin{array}{l}0.321 * * * \\
(0.080)\end{array}$ & $\begin{array}{c}0.148 \\
(0.114)\end{array}$ & $\begin{array}{l}0.536^{* * * *} \\
(0.010)\end{array}$ \\
\hline College or more & $\begin{array}{l}0.681 * * * \\
(0.095)\end{array}$ & $\begin{array}{c}0.137 \\
(0.117)\end{array}$ & $\begin{array}{l}0.481 \text { *** } \\
(0.135)\end{array}$ & $\begin{array}{l}0.920 * * * \\
(0.014)\end{array}$ \\
\hline Observations & 6,895 & 5,326 & 6,380 & 378,935 \\
\hline \multicolumn{5}{|l|}{ Panel B: 2002-2013 } \\
\hline High school & $\begin{array}{l}0.283^{* * *} \\
(0.053)\end{array}$ & $\begin{array}{l}0.225^{* * *} \\
(0.053)\end{array}$ & $\begin{array}{l}0.438 * * * \\
(0.085)\end{array}$ & $\begin{array}{l}0.409 * * * \\
(0.007)\end{array}$ \\
\hline Some college & $\begin{array}{l}0.418^{* * * *} \\
(0.069)\end{array}$ & $\begin{array}{l}0.358^{* * * *} \\
(0.071)\end{array}$ & $\begin{array}{l}0.608^{* * * *} \\
(0.103)\end{array}$ & $\begin{array}{l}0.644 * * * \\
(0.010)\end{array}$ \\
\hline College or more & $\begin{array}{l}0.512 * * * \\
(0.067)\end{array}$ & $\begin{array}{c}0.197^{*} \\
(0.105)\end{array}$ & $\begin{array}{l}0.969 * * * \\
(0.108)\end{array}$ & $\begin{array}{l}1.080 * * * \\
(0.011)\end{array}$ \\
\hline Observations & 10,323 & 6,228 & 9,829 & 526,164 \\
\hline
\end{tabular}

Source: Author's analysis of the 1992-2014 March CPS

Notes: The dependent variable is the log of hourly wages. The omitted education category is less than a high school degree. All models include controls for age, age-squared, race and ethnicity (four dummy variables), marital status (five dummy variables), southern state residence (one dummy variable), and year-specific effects. All specifications are estimated using the se $\mathrm{lmlog}$ Stata command developed by Bourguignon et al. (2007). The exclusion restrictions (from the multinomial sectoral choice model) include family size, family size-squared, and real non-wage income. Selection correction terms are those developed in Dubin \& McFadden (1984).***,**, and * indicate statistical significance at the $0.01,0.05$, and 0.10 levels, respectively. 
Table 12: Center-Based Child Care Regulations, 1983-2010

\begin{tabular}{|c|c|c|c|}
\hline Regulation & 1990 & 2010 & Time Trend \\
\hline \multicolumn{4}{|l|}{ Director's Education: no. states (\%) } \\
\hline No regulation & $6(0.133)$ & $2(0.044)$ & \multirow{5}{*}{$\begin{array}{c}-0.017 * \\
(0.010)\end{array}$} \\
\hline High school/GED & $12(0.267)$ & $17(0.378)$ & \\
\hline Post-high school certification & $4(0.089)$ & $13(0.289)$ & \\
\hline Associate's degree & $17(0.378)$ & $10(0.222)$ & \\
\hline Bachelor's degree & $6(0.133)$ & $3(0.067)$ & \\
\hline \multicolumn{4}{|l|}{ Teacher's Education: no. states (\%) } \\
\hline No regulation & $16(0.340)$ & $12(0.255)$ & \multirow{5}{*}{$\begin{array}{c}0.011 * \\
(0.006)\end{array}$} \\
\hline High school/GED & $23(0.489)$ & $27(0.575)$ & \\
\hline Post-high school certification & $3(0.064)$ & $6(0.128)$ & \\
\hline Associate's degree & $4(0.085)$ & $1(0.021)$ & \\
\hline Bachelor's degree & $1(0.021)$ & $1(0.021)$ & \\
\hline \multicolumn{4}{|l|}{ Child-to-staff ratios: mean $(S D)$} \\
\hline 2-year-olds & $7.09(2.26)$ & $7.11(2.09)$ & \multirow{2}{*}{$\begin{array}{l}0.015^{* * *} \\
(0.003) \\
-0.019^{* * *} \\
(0.002)\end{array}$} \\
\hline 4-year-olds & $12.94(3.18)$ & $12.52(2.81)$ & \\
\hline Regulation & 1983 & 2000 & Time Trend \\
\hline \multicolumn{4}{|l|}{ Maximum group size: < 1-year-old } \\
\hline No regulation: no. states (\%) & $28(0.609)$ & $20(0.435)$ & \multirow{2}{*}{$\begin{array}{l}0.254^{* * * *} \\
(0.019)\end{array}$} \\
\hline Mean $(S D)$ & $8.83(2.66)$ & $9.12(3.15)$ & \\
\hline \multicolumn{4}{|l|}{ Maximum group size: 1 -year-olds } \\
\hline No regulation & $28(0.609)$ & $20(0.435)$ & \multirow{2}{*}{$\begin{array}{l}0.333 * * * \\
(0.024)\end{array}$} \\
\hline Mean & $10.39(3.71)$ & $11.04(3.64)$ & \\
\hline \multicolumn{4}{|l|}{ Maximum group size: 2 -year-olds } \\
\hline No regulation & $28(0.596)$ & $19(0.404)$ & \multirow{2}{*}{$\begin{array}{l}0.449 * * * \\
(0.038)\end{array}$} \\
\hline Mean & $15.68(4.42)$ & $15.04(4.88)$ & \\
\hline \multicolumn{4}{|l|}{ Maximum group size: 3 -year-olds } \\
\hline No regulation & $30(0.652)$ & $23(0.500)$ & \multirow{2}{*}{$\begin{array}{l}0.628 * * * \\
(0.049)\end{array}$} \\
\hline Mean & $19.94(4.67)$ & $21.26(4.29)$ & \\
\hline \multicolumn{4}{|l|}{ Maximum group size: 4 -year-olds } \\
\hline No regulation & $30(0.652)$ & $23(0.500)$ & \multirow{2}{*}{$\begin{array}{l}0.678 \text { *** } \\
(0.050)\end{array}$} \\
\hline Mean & $22.06(2.95)$ & $23.65(4.61)$ & \\
\hline \multicolumn{4}{|l|}{ Maximum group size: 5+-year-olds } \\
\hline No regulation & $30(0.652)$ & $23(0.500)$ & \multirow{2}{*}{$\begin{array}{l}0.751^{* * *} \\
(0.056)\end{array}$} \\
\hline Mean & $25.38(5.48)$ & $26.43(5.38)$ & \\
\hline
\end{tabular}

Source: Author's analysis of child care regulation data collected by Daphna Bassok and colleagues (19902010) and V. Joseph and Rebecca Kilburn (1983-2000)

Notes: The category "post-high school certification" includes post-secondary credits and the CDA. The group size means are calculated using states that regulate group size in a given age group. The time trend regressions are estimated using ordered probit for the education outcomes, OLS for child-to-staff ratios, and tobit for group sizes. The tobits are censored on states without a group size regulation (i.e., set equal to zero). The regressions include a linear time trend and an intercept. Standard errors (in parentheses) are adjusted for clustering in year-specific cells. The number of observations in the regressions are: 734 (director's education); 739 (teacher's education); 1,005 (ratio for 2-year-olds), 983 (ratio for 4-year-olds); and $903,898,907,905,905$, and 905 (group size age 0 to 5, respectively). ***, **, and * indicate statistical significance at the $0.01,0.05$, and 0.10 levels, respectively. 
Table 13: The Effect of Center-Based Child Care Regulations on the Child Care Market

\begin{tabular}{|c|c|c|c|c|}
\hline \multirow[b]{2}{*}{ Variable } & \multicolumn{3}{|c|}{ QCEW: 1990-2010 } & \multirow{2}{*}{$\begin{array}{c}\text { CPS: 1991-2010 } \\
\text { Center-Based } \\
\text { Worker }\end{array}$} \\
\hline & $\begin{array}{c}\text { Establishments } \\
\text { Per Capita }\end{array}$ & $\begin{array}{c}\text { Employment } \\
\text { Per Capita }\end{array}$ & $\begin{array}{l}\text { Weekly } \\
\text { Earnings }\end{array}$ & \\
\hline \multicolumn{5}{|l|}{ Director's Education } \\
\hline HS/GED & $\begin{array}{l}-0.137 * * \\
(0.064)\end{array}$ & $\begin{array}{l}-0.113 * * \\
(0.054)\end{array}$ & $\begin{array}{l}-0.046 * * \\
(0.021)\end{array}$ & $\begin{array}{l}-0.0019 * * \\
(0.0008)\end{array}$ \\
\hline Post-HS certification & $\begin{array}{l}-0.125 \\
(0.077)\end{array}$ & $\begin{array}{l}-0.136^{*} \\
(0.078)\end{array}$ & $\begin{array}{l}-0.046^{* *} \\
(0.020)\end{array}$ & $\begin{array}{l}-0.0010 \\
(0.0012)\end{array}$ \\
\hline Associate's degree & $\begin{array}{l}-0.193 * * * \\
(0.068)\end{array}$ & $\begin{array}{l}-0.146 * * \\
(0.058)\end{array}$ & $\begin{array}{l}-0.045^{* *} \\
(0.019)\end{array}$ & $\begin{array}{l}-0.0027 * * * \\
(0.0009)\end{array}$ \\
\hline Bachelor's degree & $\begin{array}{l}-0.260 * * * \\
(0.072)\end{array}$ & $\begin{array}{l}-0.177 * * * \\
(0.060)\end{array}$ & $\begin{array}{c}0.008 \\
(0.035)\end{array}$ & $\begin{array}{l}-0.0035^{* * *} \\
(0.0010)\end{array}$ \\
\hline \multicolumn{5}{|l|}{ Teacher's Education } \\
\hline HS/GED & $\begin{array}{c}0.035 \\
(0.051)\end{array}$ & $\begin{array}{c}0.017 \\
(0.032)\end{array}$ & $\begin{array}{c}0.026^{*} \\
(0.015)\end{array}$ & $\begin{array}{l}-0.0006 \\
(0.0006)\end{array}$ \\
\hline Post-HS certification & $\begin{array}{c}0.002 \\
(0.072)\end{array}$ & $\begin{array}{l}0.008 \\
(0.076)\end{array}$ & $\begin{array}{l}0.055^{* *} \\
(0.022)\end{array}$ & $\begin{array}{c}0.0013 \\
(0.0015)\end{array}$ \\
\hline Associate's degree & $\begin{array}{c}0.102 \\
(0.066)\end{array}$ & $\begin{array}{c}0.050 \\
(0.045)\end{array}$ & $\begin{array}{c}0.040 \\
(0.030)\end{array}$ & $\begin{array}{l}-0.0001 \\
(0.0012)\end{array}$ \\
\hline Bachelor's degree & $\begin{array}{l}-0.028 \\
(0.101)\end{array}$ & $\begin{array}{l}-0.138 * * * \\
(0.048)\end{array}$ & $\begin{array}{c}0.024 \\
(0.015)\end{array}$ & $\begin{array}{c}0.0059 \\
(0.0038)\end{array}$ \\
\hline \multicolumn{5}{|l|}{ Child-to-Staff Ratios } \\
\hline 2-year-olds & $\begin{array}{l}-0.013 * * \\
(0.006)\end{array}$ & $\begin{array}{l}-0.019 * * \\
(0.008)\end{array}$ & $\begin{array}{c}0.002 \\
(0.005)\end{array}$ & $\begin{array}{l}-0.0004 * * * \\
(0.0001)\end{array}$ \\
\hline 4-year-olds & $\begin{array}{c}0.006 \\
(0.006)\end{array}$ & $\begin{array}{c}0.001 \\
(0.007)\end{array}$ & $\begin{array}{c}0.001 \\
(0.002)\end{array}$ & $\begin{array}{c}0.0000 \\
(0.0001)\end{array}$ \\
\hline Observations & 1,071 & 1,069 & 1,071 & $1,115,373$ \\
\hline Observable controls & Yes & Yes & Yes & Yes \\
\hline Year/state fixed effects & Yes & Yes & Yes & Yes \\
\hline
\end{tabular}

Source: Author's analysis of the 1990-2010 QCEW and the 1992-2011 March CPS.

Notes: The dependent variables are, respectively, log of child care establishments per capita, log of child care employment per capita, log of weekly child care earnings, and multinomial sectoral choice. Non-working women comprise the omitted category in the multinomial logit model. In the multinomial logit model, the marginal effects are evaluated at the variable means. The education regulations are dummy variables, using states without a given regulation as the omitted category. The staff-to-child ratios are treated as continuous variables. See the text for a description of the state-level controls in the QCEW analysis. See the notes to Table 10 for a description of the individual-level controls in the CPS analysis (except for Southern state residence). All models include year and state fixed effects. The QCEW regressions are weighed by the state population, and standard errors are adjusted for within-state clustering. Standard errors in the CPS analysis are adjusted for within-state clustering. $* * * * *$, and $*$ indicate statistical significance at the $0.01,0.05$, and 0.10 levels, respectively. 
Appendix Table 1: SIPP Child Care Arrangement Cross Walk

\begin{tabular}{|c|c|c|}
\hline $\begin{array}{l}1990 \text { SIPP, Wave } 3 \\
\text { Fall } 1990\end{array}$ & $\begin{array}{l}2008 \text { SIPP, Wave } 8 \\
\text { Winter/Spring } 2011\end{array}$ & $\begin{array}{c}\text { Type of } \\
\text { Arrangement }\end{array}$ \\
\hline $\begin{array}{l}\text { 1. Parent works at home } \\
\text { Unpaid arrangement } \\
\text { Ages } 0-14\end{array}$ & $\begin{array}{l}\text { 1a. Parent or guardian at home } \\
\text { Unpaid arrangement } \\
\text { Ages } 0-14\end{array}$ & Parent \\
\hline $\begin{array}{l}\text { 2. Parent cares for child at work } \\
\text { Unpaid arrangement } \\
\text { Ages } 0-14\end{array}$ & $\begin{array}{l}\text { 1b. Parent or guardian at work } \\
\text { Unpaid arrangement } \\
\text { Ages } 0-14\end{array}$ & Parent \\
\hline $\begin{array}{l}\text { 3. Other parent/stepparent } \\
\text { Unpaid arrangement } \\
\text { Ages } 0-14\end{array}$ & $\begin{array}{l}\text { 2. Other parent/stepparent } \\
\text { Unpaid arrangement } \\
\text { Ages } 0-14\end{array}$ & Parent \\
\hline $\begin{array}{l}\text { 4. Brother/sister } \\
\text { Unpaid arrangement } \\
\text { Ages 0-14 }\end{array}$ & $\begin{array}{l}\text { 3. Sibling ages } 15 \text { or older } \\
\text { Unpaid arrangement } \\
\text { Ages } 0-14 \\
\text { 4. Sibling under age } 15 \\
\text { Unpaid arrangement } \\
\text { Ages } 0-14\end{array}$ & Relative \\
\hline $\begin{array}{l}\text { 5. Grandparent } \\
\text { Paid arrangement } \\
\text { Ages } 0-14\end{array}$ & $\begin{array}{l}\text { 5. Grandparent } \\
\text { Paid arrangement } \\
\text { Ages } 0-14\end{array}$ & Relative \\
\hline $\begin{array}{l}\text { 6. Other relative of child } \\
\text { Paid arrangement } \\
\text { Ages } 0-14\end{array}$ & $\begin{array}{l}\text { 6. Any other relative } \\
\text { Paid arrangement } \\
\text { Ages } 0-14\end{array}$ & Relative \\
\hline $\begin{array}{l}\text { 7a. Non-relative inside child's home } \\
\text { Paid arrangement } \\
\text { Ages } 0-14\end{array}$ & $\begin{array}{l}\text { 7. Non-relative in/outside child's home } \\
\text { Paid arrangement } \\
\text { Ages } 0-14\end{array}$ & Non-relative \\
\hline $\begin{array}{l}\text { 7b. Non-relative outside child's home } \\
\text { Paid arrangement } \\
\text { Ages } 0-14\end{array}$ & $\begin{array}{l}\text { 8. Family day care provider } \\
\text { Paid arrangement } \\
\text { Ages } 0-14\end{array}$ & Family-based \\
\hline $\begin{array}{l}\text { 8. Day/group care center } \\
\text { Paid arrangement } \\
\text { Ages } 0-14\end{array}$ & $\begin{array}{l}\text { 9. Child or day care center } \\
\text { Paid arrangement } \\
\text { Ages } 0-14\end{array}$ & Center-based \\
\hline $\begin{array}{l}\text { 9. Nursery/preschool } \\
\text { Paid arrangement } \\
\text { Ages } 0-14\end{array}$ & $\begin{array}{l}\text { 10. Nursery/preschool } \\
\text { Paid arrangement } \\
\text { Ages } 0-5 \\
\text { 11. Head Start } \\
\text { Paid arrangement } \\
\text { Ages 0-5 }\end{array}$ & Preschool/Nursery \\
\hline $\begin{array}{l}\text { 10. Kindergarten/elementary/secondary } \\
\text { school } \\
\text { Unpaid arrangement } \\
\text { Ages } 0-14 \\
\end{array}$ & $\begin{array}{l}\text { 12. School } \\
\text { Unpaid arrangement } \\
\text { Ages 4-5 and 6-14 }\end{array}$ & Kindergarten/School \\
\hline $\begin{array}{l}\text { 11. Organized school-based activity } \\
\text { Paid arrangement } \\
\text { Ages } 0-14\end{array}$ & $\begin{array}{l}\text { 13. Before/after school program in school } \\
\text { 14 Organized sports in school } \\
\text { 15. Lessons in school } \\
\text { 16. Clubs in school } \\
\text { Paid arrangements } \\
\text { Ages 6-14 }\end{array}$ & School-based activity \\
\hline $\begin{array}{l}\text { 12. Child cares for self } \\
\text { Unpaid arrangement } \\
\text { Ages } 0-14\end{array}$ & $\begin{array}{l}\text { 17. Child cared for self } \\
\text { Unpaid arrangement } \\
\text { Ages } 4-5 \text { and 6-14 }\end{array}$ & Self-care \\
\hline
\end{tabular}




\begin{tabular}{ll}
\hline Unmatched Arrangements & Unmatched Arrangements \\
N/A & 18. Before/after school program out of N/A \\
& school \\
& 19. Organized sports out of school \\
& 20. Lessons out of school \\
& 21. Clubs out of school \\
& Paid arrangements \\
& Ages 6-14 \\
\hline
\end{tabular}


Appendix Table 2: Percent Change in Annual Earnings of Private-Sector Child Care Employees, by State, 1990-2013

\begin{tabular}{|c|c|c|c|}
\hline State & 1990-2013 & 1990-2004 & 2004-2013 \\
\hline Alabama & 0.095 & 0.048 & 0.044 \\
\hline Alaska & 0.153 & 0.128 & 0.021 \\
\hline Arizona & 0.373 & 0.459 & -0.059 \\
\hline Arkansas & 0.347 & 0.245 & 0.081 \\
\hline California & 0.353 & 0.335 & 0.012 \\
\hline Colorado & 0.391 & 0.382 & 0.006 \\
\hline Connecticut & -0.012 & 0.017 & -0.028 \\
\hline Delaware & 0.344 & 0.297 & 0.035 \\
\hline District of Columbia & 0.299 & 0.248 & 0.040 \\
\hline Florida & 0.226 & 0.260 & -0.027 \\
\hline Georgia & 0.238 & 0.239 & -0.001 \\
\hline Hawaii & 0.250 & 0.185 & 0.054 \\
\hline Idaho & 0.251 & 0.316 & -0.049 \\
\hline Illinois & 0.294 & 0.281 & 0.009 \\
\hline Indiana & 0.310 & 0.344 & -0.025 \\
\hline Iowa & 0.303 & 0.218 & 0.068 \\
\hline Kansas & 0.362 & 0.344 & 0.012 \\
\hline Kentucky & 0.270 & 0.274 & -0.003 \\
\hline Louisiana & 0.279 & 0.206 & 0.059 \\
\hline Maine & 0.172 & 0.193 & -0.018 \\
\hline Maryland & 0.262 & 0.250 & 0.009 \\
\hline Massachusetts & 0.114 & 0.170 & -0.048 \\
\hline Michigan & 0.204 & 0.317 & -0.086 \\
\hline Minnesota & 0.308 & 0.352 & -0.033 \\
\hline Mississippi & 0.038 & 0.098 & -0.055 \\
\hline Missouri & 0.242 & 0.286 & -0.034 \\
\hline Montana & 0.273 & 0.243 & 0.023 \\
\hline Nebraska & 0.279 & 0.324 & -0.034 \\
\hline Nevada & 0.312 & 0.260 & 0.041 \\
\hline New Hampshire & 0.180 & 0.176 & 0.001 \\
\hline New Jersey & 0.232 & 0.284 & -0.040 \\
\hline New Mexico & 0.350 & 0.415 & -0.045 \\
\hline New York & 0.029 & 0.039 & -0.010 \\
\hline North Carolina & 0.296 & 0.285 & 0.008 \\
\hline North Dakota & 0.182 & 0.079 & 0.095 \\
\hline Ohio & 0.265 & 0.329 & -0.048 \\
\hline Oklahoma & 0.363 & 0.278 & 0.065 \\
\hline Oregon & 0.432 & 0.472 & -0.027 \\
\hline Pennsylvania & 0.237 & 0.217 & 0.015 \\
\hline Rhode Island & 0.123 & 0.252 & -0.103 \\
\hline South Carolina & 0.284 & 0.256 & 0.021 \\
\hline South Dakota & 0.230 & 0.309 & -0.060 \\
\hline Tennessee & 0.221 & 0.144 & 0.066 \\
\hline Texas & 0.265 & 0.227 & 0.031 \\
\hline Utah & 0.488 & 0.458 & 0.020 \\
\hline Vermont & 0.191 & 0.158 & 0.027 \\
\hline Virginia & 0.321 & 0.269 & 0.040 \\
\hline Washington & 0.423 & 0.322 & 0.075 \\
\hline West Virginia & 0.256 & 0.213 & 0.034 \\
\hline Wisconsin & 0.308 & 0.371 & -0.046 \\
\hline Wyoming & 0.500 & 0.344 & 0.115 \\
\hline
\end{tabular}


Appendix Table 3: Summary Statistics for the CPS Sample of Women, 1991-2013

\begin{tabular}{|c|c|c|c|c|c|}
\hline & $\begin{array}{c}\text { Center-Based } \\
\text { Workers }\end{array}$ & $\begin{array}{c}\text { Home-Based } \\
\text { Workers }\end{array}$ & $\begin{array}{c}\text { School-Based } \\
\text { Workers }\end{array}$ & $\begin{array}{l}\text { All Other } \\
\text { Workers }\end{array}$ & $\begin{array}{c}\text { Non- } \\
\text { Workers }\end{array}$ \\
\hline \multirow[t]{2}{*}{ Age } & 35.71 & 37.93 & 41.97 & 39.30 & 40.94 \\
\hline & (12.22) & (12.16) & $(10.75)$ & (11.94) & $(14.05)$ \\
\hline \multirow[t]{2}{*}{ White } & 0.646 & 0.664 & 0.701 & 0.687 & 0.575 \\
\hline & $(0.478)$ & $(0.472)$ & $(0.458)$ & $(0.464)$ & $(0.494)$ \\
\hline \multirow[t]{2}{*}{ Black } & 0.151 & 0.099 & 0.102 & 0.110 & 0.127 \\
\hline & $(0.358)$ & $(0.299)$ & $(0.302)$ & $(0.313)$ & $(0.333)$ \\
\hline \multirow[t]{2}{*}{ Hispanic } & 0.151 & 0.187 & 0.149 & 0.135 & 0.216 \\
\hline & $(0.358)$ & $(0.390)$ & $(0.356)$ & $(0.342)$ & $(0.411)$ \\
\hline \multirow[t]{2}{*}{ Asian } & 0.026 & 0.029 & 0.024 & 0.048 & 0.057 \\
\hline & $(0.160)$ & $(0.167)$ & $(0.154)$ & $(0.213)$ & $(0.232)$ \\
\hline \multirow[t]{2}{*}{ Other } & 0.026 & 0.021 & 0.024 & 0.020 & 0.026 \\
\hline & $(0.158)$ & $(0.143)$ & $(0.152)$ & $(0.142)$ & (0.159) \\
\hline \multirow[t]{2}{*}{ Married } & 0.535 & 0.596 & 0.723 & 0.559 & 0.591 \\
\hline & $(0.499)$ & $(0.491)$ & $(0.447)$ & $(0.497)$ & $(0.491)$ \\
\hline \multirow[t]{2}{*}{ Married } & 0.014 & 0.017 & 0.009 & 0.012 & 0.014 \\
\hline & $(0.116)$ & $(0.128)$ & $(0.095)$ & (0.109) & (0.119) \\
\hline \multirow[t]{2}{*}{ Separated } & 0.034 & 0.034 & 0.025 & 0.029 & 0.032 \\
\hline & $(0.182)$ & $(0.182)$ & $(0.156)$ & $(0.169)$ & $(0.177)$ \\
\hline \multirow[t]{2}{*}{ Divorced } & 0.083 & 0.094 & 0.079 & 0.129 & 0.083 \\
\hline & $(0.275)$ & $(0.291)$ & $(0.270)$ & $(0.335)$ & $(0.276)$ \\
\hline \multirow[t]{2}{*}{ Widowed } & 0.017 & 0.025 & 0.022 & 0.022 & 0.043 \\
\hline & $(0.129)$ & $(0.157)$ & $(0.147)$ & $(0.146)$ & $(0.207)$ \\
\hline \multirow[t]{2}{*}{ Never married } & 0.318 & 0.234 & 0.141 & 0.249 & 0.236 \\
\hline & $(0.466$ & $(0.423)$ & $(0.348)$ & $(0.432)$ & $(0.424)$ \\
\hline \multirow[t]{2}{*}{ Less than HS } & 0.086 & 0.172 & 0.028 & 0.091 & 0.256 \\
\hline & $(0.280)$ & $(0.377)$ & $(0.165)$ & $(0.288)$ & $(0.436)$ \\
\hline \multirow[t]{2}{*}{ HS } & 0.313 & 0.353 & 0.288 & 0.295 & 0.332 \\
\hline & $(0.464)$ & $(0.478)$ & $(0.453)$ & $(0.456)$ & $(0.471)$ \\
\hline \multirow[t]{2}{*}{ Some college } & 0.391 & 0.345 & 0.366 & 0.321 & 0.250 \\
\hline & $(0.488)$ & $(0.475)$ & $(0.482)$ & $(0.467)$ & $(0.433)$ \\
\hline \multirow[t]{2}{*}{ College or more } & 0.211 & 0.131 & 0.318 & 0.293 & 0.163 \\
\hline & $(0.408)$ & $(0.337)$ & $(0.466)$ & $(0.455)$ & $(0.369)$ \\
\hline \multirow[t]{2}{*}{ Child ages 0-2 } & 0.132 & 0.147 & 0.067 & 0.100 & 0.149 \\
\hline & $(0.338)$ & $(0.354)$ & $(0.250)$ & $(0.300)$ & $(0.356)$ \\
\hline \multirow[t]{2}{*}{ Child ages 3-5 } & 0.113 & 0.120 & 0.068 & 0.081 & 0.094 \\
\hline & $(0.316)$ & $(0.325)$ & $(0.252)$ & $(0.272)$ & $(0.292)$ \\
\hline \multirow[t]{2}{*}{ Child ages 6-12 } & 0.180 & 0.175 & 0.275 & 0.162 & 0.129 \\
\hline & $(0.384)$ & $(0.380)$ & $(0.446)$ & $(0.369)$ & $(0.335)$ \\
\hline \multirow[t]{2}{*}{ Child ages 13-17 } & 0.091 & 0.100 & 0.176 & 0.107 & 0.071 \\
\hline & $(0.287)$ & $(0.300)$ & $(0.381)$ & $(0.310)$ & $(0.256)$ \\
\hline \multirow[t]{2}{*}{ Child ages $18+$} & 0.085 & 0.098 & 0.120 & 0.095 & 0.101 \\
\hline & $(0.278)$ & $(0.298)$ & $(0.325)$ & $(0.293)$ & $(0.302)$ \\
\hline \multirow[t]{2}{*}{ Family size } & 3.398 & 3.488 & 3.463 & 3.032 & 3.407 \\
\hline & $(1.552)$ & $(1.632)$ & $(1.411)$ & $(1.543)$ & $(1.767)$ \\
\hline Southern residence & 0.332 & 0.236 & 0.273 & 0.302 & 0.336 \\
\hline & $(0.471)$ & $(0.424)$ & $(0.445)$ & $(0.459)$ & $(0.472)$ \\
\hline Non-wage income & 54,242 & 49,546 & 62,090 & 51,855 & 59,766 \\
\hline & $(66,815)$ & $(59,907)$ & $(61,039)$ & $(66,929)$ & $(79,484)$ \\
\hline
\end{tabular}

Source: Author's analysis of the 1992-2014 March CPS

Notes: Standard deviations are in parentheses. 